\title{
Thermodynamic Properties of Some Gaseous Halogen Compounds
}

\author{
William H. Evans, Thomas R. Munson, ${ }^{1}$ and Donald D. Wagman
}

\begin{abstract}
Tables of values of the heat of formation, $\Delta H f^{\circ}$; free energy of formation, $\Delta F f^{\circ}$; $\log$ arithm of the equilibrium constant of formation, $\log _{10} K f^{\prime}$; free-energy function, $\left(F^{\circ}-H_{0}^{\circ}\right) / T$; heatcontent function, $\left(H^{\circ}-H_{0}^{\circ}\right) / T$; entropy, $S^{\circ}$; heat content, $\left(H^{\circ}-H_{0}^{\circ}\right)$, and heat capacity, $C_{p}^{\circ}$, are given from $0^{\circ} \mathrm{K}$ to high temperatures for the following gaseous substances: $\mathrm{F}, \mathrm{F}_{2}$, $\mathrm{F}_{2} \mathrm{O}, \mathrm{Cl}, \mathrm{Cl}_{2}, \mathrm{ClO}_{2}, \mathrm{Cl}_{2} \mathrm{O}, \mathrm{ClF}, \mathrm{ClF}_{3}, \mathrm{Br}, \mathrm{Br}_{2}, \mathrm{BrF}, \mathrm{BrF}_{5}, \mathrm{BrCl}, \mathrm{I}, \mathrm{I}_{2}, \mathrm{IF}, \mathrm{IF}_{5}, \mathrm{IF}_{7}, \mathrm{ICl}$ and IBr. The data used in preparing the tables are discussed in detail.
\end{abstract}

\section{Introduction}

As part of the general program of the National Bureau of Standards on the collection, analysis, and compilation of data on the chemical thermodynamic properties of substances $[1,2]^{2}$, the available information relating to the heats and free energies of formation and the thermodynamic functions of a number of gaseous halogen and oxyhalogen molecules has been assembled and reviewed. Tables of selected values of the heat of formation, $\Delta H f^{\circ}$; free energy of formation, $\Delta F f^{\circ}$; logarithm of the equilibrium constant of formation, $\log _{10} K f$; freeenergy function, $\left(F^{\circ}-H_{0}^{\circ}\right) / T$; heat-content function, $\left(H^{\circ}-H_{0}^{\circ}\right) / T$; entropy, $S^{\circ}$; heat content, $\left(H^{\circ}-H_{0}^{\circ}\right)$; and heat capacity, $C_{p}^{\circ}$, are given from $0^{\circ} \mathrm{K}$ to high temperatures for the gaseous substances $\mathrm{F}$, $\mathrm{F}_{2}, \mathrm{~F}_{2} \mathrm{O}, \mathrm{Cl}, \mathrm{Cl}_{2}, \mathrm{ClO}_{2}, \mathrm{ClF}, \mathrm{ClF}_{3}, \mathrm{Br}, \mathrm{Br}_{2}, \mathrm{BrF}, \mathrm{BrF}_{5}$, $\mathrm{BrCl}, \mathrm{I}, \mathrm{I}_{2}, \mathrm{IF}, \mathrm{IF}_{5}, \mathrm{IF}_{7}, \mathrm{ICl}$, and IBr. Some of the values reported here have been published [1], but no analysis of the data used to obtain the values was given. The present report not only includes a discussion of the sources and treatment of the data but also makes use of the available molecular and spectroscopic data to extend the tables to include values for high temperatures. It is this hightemperature region that is of great interest and importance to many engineers, chemists, and physicists working in the fields of reaction kinetics, fuels, propellants, and explosives.

\section{Units and Standard States}

The calorie used in these calculations is the thermochemical calorie, defined as 4.1840 abs $j$. The other constants used are those given by Wagman et al. [2]. The ice point, $0^{\circ} \mathrm{C}$, is taken as $273.16^{\circ} \mathrm{K}$ [3]. The chemical atomic weights used are [4] O, $16 ; \mathrm{F}, 19.00 ; \mathrm{Cl}, 35.457 ; \mathrm{Br}, 79.916 ; \mathrm{I}, 126.91$. The standard state chosen for all gases is the ideal gas at 1 -atm pressure. $A s$ is customary, nuclear spin and isotopic mixing effects are omitted; all

1 Present address: The Vitro Laboratories, West Orange, N. J.

${ }_{2}^{2}$ Figures in brackets indicate the literature references at the end of this paper. values are for the naturally occurring isotopic mixture.

\section{Calculations of the Thermodynamic Functions}

\subsection{Monatomic Gases}

The translational contributions to the thermodynamic functions of the monatomic gases $\mathrm{F}, \mathrm{Cl}$, $\mathrm{Br}$, and I were calculated by use of the equations given by Wagman et al. [2] (corrected for the new definition of the thermochemical calorie). The additional contributions due to electronic excitation were evaluated by direct summation [5]. The energy levels and multiplicities used were taken from Moore [6].

\subsection{Diatomic Gases}

The translational contributions to the thermodynamic functions for the diatomic molecules other than $\mathrm{F}_{2}$ and $\mathrm{ClF}$ were evaluated with the same equations used for the monatomic gases [2]. The rotational and vibrational constants given in table 1 were used to calculate the thermodynamic functions for a rigid rotator [2] with moment of inertia $I$, equal to $h /\left[8 \pi^{2} c B_{e}\left(1-\alpha_{e} / 2\right)\right]$, and an independent harmonic oscillator [8] with a fundamental frequency $\left(\omega_{e}-2 x_{e} \omega_{e}\right) .^{3}$ These constants have been adjusted to the usual isotopic mixture, using the product rule; isotopic masses were taken from Collins, Nier, and Johnson [9] $(\mathrm{Cl})$, and Bainbridge and Nier [10] $(\mathrm{Br})$.

Corrections for rotational stretching, vibrational anharmonicity, and rotational-vibrational interaction were calculated at $250^{\circ}, 300^{\circ}, 500^{\circ}, 1,000^{\circ}$, and $1,500^{\circ} \mathrm{K}$ (and $2,000^{\circ}, 2,500^{\circ}$, and $3,000^{\circ} \mathrm{K}$ for $\mathrm{Cl}_{2}, \mathrm{Br}_{2}$, and $\mathrm{I}_{2}$ ), using equations [5] based on the treatment of the general diatomic molecule given by Mayer and Mayer [11]. Values at intermediate temperatures were obtained by graphical interpolation. Table 2 shows the magnitude of these corrections at $1,500^{\circ} \mathrm{K}$.

\footnotetext{
3 The spectroscopic notation is that used by Herzberg [14].
} 
TABLE 1. Molecular constants used in calculating the thermodynamic functions for the diatomic halogen molecules

\begin{tabular}{|c|c|c|c|c|c|}
\hline & $B_{e}$ & $\alpha_{e}$ & $\omega_{e}$ & $x_{e} \omega_{e}$ & $10^{8} D_{e}$ \\
\hline $\mathrm{F}_{2 \ldots}$ & $\begin{array}{c}\mathrm{cm}^{-1} \\
0.8901 \\
{[12,13]}\end{array}$ & $\begin{array}{c}c m^{-1} \\
0.0146 \\
{[7]}\end{array}$ & $\begin{array}{c}c m^{-1} \\
919.0 \\
{[12,13]}\end{array}$ & $\begin{array}{c}\mathrm{cm}^{-1} \\
13.6 \\
{[7]}\end{array}$ & $\begin{array}{c}\mathrm{cm}^{-1} \\
334 . \\
{[7]}\end{array}$ \\
\hline $\mathrm{Cl}_{2 \ldots}$ & $\begin{array}{l}0.2404 \\
{[14]}\end{array}$ & $\begin{array}{r}0.00166 \\
{[14]}\end{array}$ & $\begin{array}{r}561.0 \\
{[14]}\end{array}$ & $\begin{array}{r}3.94 \\
{[14]}\end{array}$ & ${ }^{\text {a }} 17.66$ \\
\hline $\mathrm{ClF}_{\ldots}$ & $\begin{array}{c}0.514012 \\
{[15]}\end{array}$ & $\begin{array}{c}0.0043272 \\
{[15]}\end{array}$ & $\begin{array}{l}784.43 \\
{[16,17]}\end{array}$ & $\begin{array}{l}6.20 \\
{[16,17]}\end{array}$ & $\begin{array}{c}86.9 \\
{[15]}\end{array}$ \\
\hline $\mathrm{Br}_{2 \ldots}$ & $\begin{array}{c}0.08092 \\
{[14]}\end{array}$ & $\begin{array}{c}0.000275 \\
{[14]}\end{array}$ & $\begin{array}{r}323.2 \\
{[14]}\end{array}$ & $\begin{array}{l}1.07 \\
{[14]}\end{array}$ & $\begin{array}{l}\text { 2. } 03 \\
{[14]}\end{array}$ \\
\hline $\mathrm{BrF}_{\ldots} \ldots$ & $\begin{array}{c}0.356319 \\
{[18]}\end{array}$ & $\begin{array}{c}0.005206 \\
{[18]}\end{array}$ & $\begin{array}{l}673, \\
{[19,20]}\end{array}$ & $\begin{array}{l}4 . \\
{[19,20]}\end{array}$ & a 40.0 \\
\hline $\mathrm{BrCl}_{\ldots} \ldots$ & $\begin{array}{c}0.150797 \\
{[21]}\end{array}$ & $\begin{array}{c}0.0007597 \\
{[21]}\end{array}$ & $\begin{array}{l}443.1 \\
{[22,23]}\end{array}$ & $\begin{array}{l}1.8 \\
{[22]}\end{array}$ & a 6.99 \\
\hline $\mathrm{I}_{2 \ldots} \ldots$ & $\begin{array}{c}0.037364 \\
{[24]}\end{array}$ & $\begin{array}{c}0.0001206 \\
{[24]}\end{array}$ & $\begin{array}{c}214.248 \\
{[24]}\end{array}$ & $\begin{array}{c}\text { b } 0.6074 \\
{[24]}\end{array}$ & a 0.455 \\
\hline IF . - & d 0.2799 & е 0.00763 & $\begin{array}{l}\text { c } 612 . \\
\text { [19] }\end{array}$ & e 4 [19] & a 23.42 \\
\hline $\mathrm{ICl}_{-}$ & $\begin{array}{c}0.112984 \\
{[25]}\end{array}$ & $\begin{array}{c}0.0005275 \\
{[25]}\end{array}$ & $\begin{array}{c}382.18 \\
{[14]}\end{array}$ & $\begin{array}{c}1.450 \\
{[14]}\end{array}$ & $\begin{array}{l}5.19 \\
{[14]}\end{array}$ \\
\hline $\mathrm{IBr}$. & d 0.05634 & e 0.000193 & $\begin{array}{r}267.4 \\
{[14]}\end{array}$ & $\begin{array}{c}0.77 \\
{[14]}\end{array}$ & a 1.00 \\
\hline
\end{tabular}

a Calculated from the relationship $D_{e}=\left(4 R_{e}^{3} / \omega_{e}^{2}\right)$ [27].

b $y_{e} \omega_{e}=0.00130 ; z_{e} \omega_{e}=0.00000525$.

c Recalculated from Durie's data [19]

d Calculated from the constants of the other halogen molecules, using Schomaker and Stevenson's relation [26].

e Calculated from the relationship $\alpha_{e}=\frac{6 B_{e}^{2}}{\omega_{e}}\left[\left(\frac{x_{e} \omega_{e}}{B_{e}}\right)^{1 / 2}-1\right][27]$

The thermodynamic functions of $\mathrm{F}_{2}$ and $\mathrm{ClF}$ were taken from unpublished calculations made by the Heat and Power Division of the Bureau [7]. These were calculated in essentially the way outlined above.

TABLE 2. Corrections added to the thermodynamic functions obtained by the rigid rotator-harmonic oscillator approximation at $1,500^{\circ} \mathrm{K}$, cal deg mole

\begin{tabular}{|c|c|c|c|}
\hline & $-\left(F^{\circ}-H_{0}^{\circ}\right) / T$ & $\left(H^{\circ}-H_{0}^{\circ}\right) / T$ & $C_{p}{ }^{\circ}$ \\
\hline 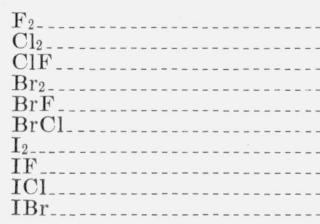 & $\begin{array}{l}0.0696 \\
.0628 \\
.0487 \\
.0629 \\
.0646 \\
.0567 \\
.0867 \\
.0563 \\
.0625 \\
.0710\end{array}$ & $\begin{array}{l}0.1083 \\
.0860 \\
.0709 \\
.0762 \\
.0894 \\
.0722 \\
.0991 \\
.0780 \\
.0776 \\
.0833\end{array}$ & $\begin{array}{l}0.247 \\
.182 \\
.156 \\
.155 \\
.190 \\
.149 \\
.200 \\
.166 \\
.159 \\
.169\end{array}$ \\
\hline
\end{tabular}

\subsection{Polyatomic Gases}

The thermodynamic functions for the polyatomic molecules, except $\mathrm{ClO}_{2}$, were calculated by using the rigid rotator-harmonic oscillator approximation $[2,8]$. The molecular data used, summarized in table 3, are as follows:

$\mathbf{F}_{2} \mathbf{O}$ (table 9). The infrared spectrum has been measured by Bernstein and Powling [28]; Jones, Kirby-Smith, Woltz, and Nielsen [29]; Hettner, Pohlman, and Schumacher [30]; and Sutherland and Penney [31]. From their data the three nondegenerate fundamental frequencies were taken as 461 , 828 , and $929 \mathrm{~cm}^{-1}$. The structural parameters nec- essary to calculate the moments of inertia were calculated by Bernstein and Powling [28] from a combination of their infrared data and various electron diffraction data; ${ }^{4}$ they obtained a $\mathrm{F}-\mathrm{O}-\mathrm{F}$ angle of $101.5 \pm 1.5^{\circ}$ and a $\mathrm{F}-\mathrm{O}$ distance of $1.38 \mathrm{~A}$. The symmetry of the molecule is $C_{2 v}$. The product $I_{A} I_{B} I_{C}$ from these data is $88.65 \times 10^{-117} \mathrm{~g}^{3} \mathrm{~cm}^{6}$.

TABLE 3. Molecular constants used in calculating the thermodynamic functions for the polyatomic halogen and oxyhalogen molecules

\begin{tabular}{|c|c|c|}
\hline Molecule & Frequencies & Moments of inertia \\
\hline $\begin{array}{l}\mathrm{F}_{2} \mathrm{O}_{2} \\
\mathrm{ClO}_{2} \mathrm{a} \\
\mathrm{Cl}_{2} \mathrm{O}_{2} \\
\mathrm{ClF}_{3} \\
\mathrm{BrF}_{5} \\
\mathrm{IF}_{5} \\
\mathrm{IF}_{7}\end{array}$ & 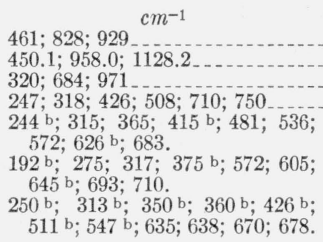 & $\begin{array}{l}\quad 10^{-39} \mathrm{gcm}^{2} \\
7.211 ; 1.424 ; 8.635 \\
8.411 ; 1.749 ; 10.160 \\
23.028 ; 2.032 ; 25.060 \\
6.1129 ; 18.1803 ; 24.3148 \\
33.77 ; 28.16 ; 28.16 \\
39.53 ; 33.03 ; 33.03 \\
52.82 ; 47.54 ; 47.54\end{array}$ \\
\hline
\end{tabular}

a Anharmonicity terms also available.

Doubly degenerate frequencies.

$\mathrm{ClO}_{2}$ (table 12). Nielsen and Woltz [33], by combining their infrared data with that of Bailey and Cassie [34], Hedberg [35], Coon [36, 37], and Coon and Ortiz [38], and with the Raman data of Kujumzelis [39], were able to obtain the harmonic fundamentals and the anharmonic constants for the ground state. Dunitz and Hedberg [40] and Coon [41] have measured the $\mathrm{Cl}-\mathrm{O}$ distance as $1.487 \mathrm{~A}$ and the $\mathrm{O}-\mathrm{Cl}-\mathrm{O}$ angle as $115.5^{\circ}$. The symmetry is $C_{2 v}$. The product $I_{A} I_{B} I_{C}$ is then $149.46 \times 10^{-117} \mathrm{~g}^{3} \mathrm{~cm}^{6}$.

These data were used to compute the thermodynamic functions for a rigid rotator-anharmonic oscillator by the method of Stockmayer, Kavanagh, and Mickley [42]. At $1,500^{\circ} \mathrm{K}$ the corrections to the harmonic oscillator approximation were 0.043 , 0.080 , and $0.174 \mathrm{cal} / \mathrm{deg}$ mole for $-\left(F^{\circ}-H_{0}^{\circ} / T\right.$, $\left(H^{\circ}-H_{0}^{\circ}\right) / T$, and $C_{p}^{\circ}$, respectively.

$\mathrm{Cl}_{2} \mathrm{O}$ (table 13). The infrared spectrum has been studied by Hedberg [35], Bailey and Cassie [43], Pohlman and Schumacher [44], and Sutherland and Penney [31]. From their data the three nondegenerate frequencies were taken as 320,684 , and $971 \mathrm{~cm}^{-1}$. Dunitz and Hedberg [40] obtained the molecular structure from electron diffraction measurements. The symmetry is $C_{2 v}$. Their values lead to a product $I_{A} I_{B} I_{C}$ of $1,173 \times 10^{-117} \mathrm{~g}^{3} \mathrm{~cm}^{6}$.

$\mathbf{C I F}_{3}$ (table 15). Jones, Parkinson, and Murray [45] have measured the Raman spectrum of the liquid and the infrared spectrum of the gas; Schäfer and Wicke [46] have also measured the Raman spectrum of the liquid. Unfortunately their assignments were based upon a pyramidal $C_{3 v}$ structure. Recently, Smith [47], from microwave measurements, and Burbank and Bensey [125], from $\mathrm{X}$-ray diffraction measurements on the solid, have

${ }^{4}$ After these calculations had been completed, Ibers and Schomaker [32] reported new electron diffraction data. They selected as the "best" values, based upon their own and upon other data, a F-O distance of $1.418 \mathrm{~A}$ and a $\mathrm{F}-\mathrm{O}-\mathrm{F}$ angle of $103.2^{\circ}$. Use of these values would increase the values of $-\left(F^{\circ}-H_{0}^{\circ}\right) / T$ and $S^{\circ}$ in table 9 by $0.16 \mathrm{cal} / \mathrm{deg}$ mole, and make the values of $\Delta F f^{\circ}$ more negative by $(0.16 T / 1000) \mathrm{keal} / \mathrm{mole}$. 
shown that the structure is a planar distorted "T" with $C_{2 v}$ symmetry. Such a molecule has six nondegenerate fundamental frequencies, all of which are both infrared and Raman active. On the basis of the $C_{v 2}$ symmetry a selection of the apparent fundamental frequencies was made from the spectral data: $247,318,426,508,710$, and $750 \mathrm{~cm}^{-1}$. The microwave data of Smith [47] give a product $I_{A} I_{B} I_{C}$ of $2702.2 \times 10^{-117} \mathrm{~g}^{3} \mathrm{~cm}^{6}$.

$\mathbf{B r F}_{5}$ (table 19). The Raman spectrum of $\mathrm{BrF}_{5}$ has been measured by Stephenson and Jones [48]; with the aid of the infrared data of Burke and Jones [49], they have assigned the fundamental frequencies based upon a $C_{4 v}$ structure. In the absence of experimental data on the structure of $\mathrm{BrF}_{5}$ it was assumed that the bromine atom is located at the center of mass and that the $\mathrm{Br}-\mathrm{F}$ distance is $1.69 \mathrm{~A}$. This distance is based on Pauling's tetrahedral radii [50] and a value for F of $0.55 \mathrm{~A}$, based on $\mathrm{CF}_{4}$. (See Allen and Sutton [51].) The product $I_{A} I_{B} I_{C}$ is then $26.78 \times 10^{-114} \mathrm{~g}^{3}$ $\mathrm{cm}^{6}$.

IF $_{5}$ (table 24). Lord, Lynch, Schumb, and Slowinski [52] have measured the Raman and infrared spectra and assigned the fundamental frequencies on the basis of a $C_{40}$ structure. The I-F distance used, $1.83 \mathrm{~A}$, was obtained in the same way as the $\mathrm{Br}-\mathrm{F}$ distance in $\mathrm{BrF}_{5}$. The product $I_{A} I_{B} I_{C}$ is then $43.13 \times 10^{-114} \mathrm{~g}^{3} \mathrm{~cm}^{6}$.

IF $_{7}$ (table 25). The Raman and infrared spectra were measured by Lord, Lynch, Schumb, and Slowinski [52]; they have assigned the fundamentals on the basis of a pentagonal bipyramidal $D_{5 h}$ structure. Slutsky and Bauer [53] report provisional electron diffraction data that lead to $1.93 \mathrm{~A}$ for the two I-F bonds along the principal rotation axis and $1.83 \mathrm{~A}$ for the radial bonds. These give a product $I_{A} I_{B} I_{C}$ of $131.62 \times 10^{-114} \mathrm{~g}^{3} \mathrm{~cm}^{6}$.

\section{Calculation of the Heats and Free Energies of Formation}

The heats of formation of gaseous $\mathrm{O}_{2}, \mathrm{~F}_{2}, \mathrm{Cl}_{2}, \mathrm{Br}_{2}$, and $\mathrm{I}_{2}$ are taken as zero (reference state); for bromine and iodine this differs from the liquid and solid states customarily used at $25^{\circ} C$ [1]. Auxiliary data, except where noted otherwise, have been taken from Rossini et al. [1].
$\mathbf{F}(\mathrm{g})$. The dissociation energy of $\mathrm{F}_{2}(\mathrm{~g})$ has been the subject of much discussion in recent years. (See the reviews by Nathans [54], Evans, Warhurst, and Whittle [55], and Herzberg [14].) From the recent experimental measurements, summarized in table 4 , we have selected the heat of dissociation of $\mathrm{F}_{2}$ as $36.7 \pm 1.0$ kcal. $^{5}$

This gives

$$
\begin{gathered}
1 / 2 \mathrm{~F}_{2}(\mathrm{~g})=\mathrm{F}(\mathrm{g}) \\
\Delta H_{0}^{\circ}=18.4 \pm 0.5 \mathrm{kcal} .
\end{gathered}
$$

$\mathbf{F}_{2} \mathbf{O}$ (g). Von Wartenberg and Klinkott [61] have measured the heat of reaction of fluorine oxide with an aqueous solution of potassium iodide containing hydrofluoric acid to give a solution of potassium triiodide and potassium fluoride; they obtained $\Delta H_{291}=-176.6 \mathrm{kcal} /$ mole. When combined with the necessary auxiliary heats of formation their data give $\Delta H f_{298.16}^{\circ} \quad \mathrm{F}_{2} \mathrm{O} \quad(\mathrm{g})=6.0 \mathrm{kcal} /$ mole. They also measured the heat of reaction of fluorine oxide with aqueous potassium hydroxide to form oxygen gas and aqueous potassium fluoride, and obtained $\Delta H_{291}=-135.8 \mathrm{kcal} / \mathrm{mole}$. This gives $\Delta H f_{298.16}^{\circ}$ $\mathrm{F}_{2} \mathrm{O}(\mathrm{g})=7.1 \mathrm{kcal} / \mathrm{mole}$. In a third experiment they measured the heat of reaction of fluorine oxide with aqueous hydrobromic acid to form a solution of bromine and hydrofluoric acid, obtaining $\Delta H_{291}=$ $-134.4 \mathrm{kcal} / \mathrm{mole}$. If corrections are applied for the heats of solution of $\mathrm{HBr}$ and $\mathrm{HF}$ in aqueous hydrobromic acid (see Ruff and Menzel [62]), this value gives $\Delta H f_{298.16}^{\circ} \quad \mathrm{F}_{2} \mathrm{O}(\mathrm{g})=9.7 \mathrm{kcal} / \mathrm{mole}$. The average was selected as the "best" value:

$$
\begin{gathered}
\mathrm{F}_{2}(\mathrm{~g})+1 / 2 \mathrm{O}_{2}(\mathrm{~g})=\mathrm{F}_{2} \mathrm{O}(\mathrm{g}) \\
\Delta H_{288.16}^{\circ}=7.6 \pm 2.0 \mathrm{kcal} .
\end{gathered}
$$

CI (g). Gaydon [63] calculated from various spectral data $D_{0}^{\circ}=19,969 \mathrm{~cm}^{-1}$, or $57.08 \mathrm{kcal}$. This gives

$$
\begin{gathered}
1 / 2 \mathrm{Cl}_{2}(\mathrm{~g})=\mathrm{Cl}(\mathrm{g}) \\
\Delta H_{0}^{\circ}=28.54 \pm 0.05 \mathrm{kcal} .
\end{gathered}
$$

\begin{tabular}{|c|c|c|c|c|}
\hline Observer & Method & $\begin{array}{l}\text { Temperature } \\
\text { range }\end{array}$ & $\begin{array}{c}\text { Number } \\
\text { of experi- } \\
\text { ments }\end{array}$ & $H_{0}^{\circ}$ a \\
\hline $\begin{array}{l}\text { Wicke and Friz }[56] \\
\text { Gilles and Margrave }[57] \\
\text { Doescher }[58] \\
\text { Wise }[59] \\
\text { Barrow and Caunt }[60]\end{array}$ & $\begin{array}{l}\mathrm{H}_{2}+\mathrm{F}_{2} \text { explosion } \\
\text { Gas density } \\
\text { Effusion } \\
\text { Dissociation of alkali hal- } \\
\text { ides. }\end{array}$ & $\begin{array}{l}{ }^{\circ} K \\
\text { Approx. } 1,000 \\
815 \text { to } 869 \\
760 \text { to } 1,115 \\
508 \text { to } 676\end{array}$ & $\begin{array}{r}5 \\
3 \\
24 \\
9 \\
\end{array}$ & $\begin{array}{l}k c a l \\
\text { 36. } 36 \pm 1.34 \\
32.07 \pm 0.76 \\
36.75 \pm 0.03 \\
38.36 \pm 0.28 \\
\text { b } 36.6 \pm 3.5\end{array}$ \\
\hline
\end{tabular}

${ }^{5}$ All uncertainties, unless otherwise indicated, represent our estimate of the over-all uncertainty.

TABLE 4. Dissociation energy of $\mathrm{F}_{2}$

a Probable error of the mean

b Over-all uncertainty as given by authors. 
Attempts have been made to measure the dissociation of $\mathrm{Cl}_{2}$ at high temperatures. Because of the difficulties of working at the high temperatures necessary to obtain measurable pressure changes, the results are not too concordant. Von Wartenberg and Henglein [64, 65] obtained gas-density data in the range $955^{\circ}$ to $1,151^{\circ} \mathrm{K}$, which lead to $D_{0}^{\circ}=53.0$ kcal. Wohl [66], from measurements of the pressure rise during explosions of $\mathrm{H}_{2}-\mathrm{Cl}_{2}$ gas mixtures, calculated $D_{0}^{\circ}=59.1 \mathrm{kcal}$. Trautz and Geissler [67] measured gas densities between $1,425^{\circ}$ and $1,537^{\circ} \mathrm{K}$; their data give $D_{0}^{\circ}=49.9 \mathrm{kcal}$. These last measurements were questioned by von Wartenberg and Weigel [68], who obtained data at $1,478^{\circ} \mathrm{K}$ that give $D_{0}^{\circ}=56.4 \mathrm{kcal}$. Except for the value from Trautz and Geissler, the results agree with the spectroscopic value within their estimated uncertainties of \pm 2 to $3 \mathrm{kcal}$.

$\mathrm{ClO}_{2}$ (g). Wallace and Goodeve [69] measured the heat of explosion of chlorine dioxide gas into the elements; their data give $\Delta H f_{298.16}^{\circ} \quad \mathrm{ClO}_{2}(\mathrm{~g})=26.3$ keal. Booth and Bowen [70] also studied this decomposition and obtained $\Delta H f_{298.16}^{\circ} \quad \mathrm{ClO}_{2}(\mathrm{~g})=23.5$ kcal. Mayer [71], from spectroscopic measurements of predissociation, obtained $\Delta H_{0}^{\circ}=3.6 \mathrm{kcal}$ for the reaction $\mathrm{ClO}_{2} \quad(\mathrm{~g})=\mathrm{Cl} \quad(\mathrm{g})+\mathrm{O}_{2} \quad(\mathrm{~g})$. This gives $\Delta H_{298.16}^{\circ} \quad \mathrm{ClO}_{2} \quad(\mathrm{~g})=24.4 \quad \mathrm{kcal}$. Finkelnburg and Schumacher [72] measured spectroscopically the ionization dissociation energy of $\mathrm{ClO}_{2}(\mathrm{~g})$ to $\mathrm{ClO}(\mathrm{g})$ and $\mathrm{O}^{+}(\mathrm{g})$ as $111 \mathrm{kcal}$. If this is combined with the dissociation energy of $\mathrm{ClO}(\mathrm{g})$ given by Parker and Wright [73], $D_{0}^{\circ}=60.7 \mathrm{kcal}$, then $\Delta H f_{298.16} \quad \mathrm{ClO}_{2}$ $(\mathrm{g})=18.7 \mathrm{kcal}$ is obtained. However, Finkelnburg and Schumacher state that their value for the dissociation energy is probably high by 5 or 6 keal because of predissociation; this correction would give a value of about $24.5 \mathrm{kcal}$ for $\Delta H f_{298.16}^{\circ} \mathrm{ClO}_{2}(\mathrm{~g})$. A value based primarily on the heats of explosion was selected:

$$
\begin{gathered}
1 / 2 \mathrm{Cl}_{2}(\mathrm{~g})+\mathrm{O}_{2}(\mathrm{~g})=\mathrm{ClO}_{2}(\mathrm{~g}) \\
\Delta H_{298.16}^{\circ}=25.0 \pm 1.5 \mathrm{kcal} .
\end{gathered}
$$

$\mathbf{C l}_{2} \mathbf{O}$ (g). Jakowkin [74] measured the solubility of chlorine gas in water and the hydrolysis equilibrium of aqueous chlorine to give aqueous hydrochloric and hypochlorous acids. Goldschmidt [75] studied the hydrolysis equilibrium of $\mathrm{Cl}_{2} \mathrm{O}$ (aq) to give hypochlorous acid, and the equilibrium distribution of $\mathrm{Cl}_{\varepsilon} \mathrm{O}$ between water and carbon tetrachloride; his data have been recalculated by Roth [76]. Yost and Felt [77] measured the solubility of $\mathrm{Cl}_{2} \mathrm{O}(\mathrm{g})$ in carbon tetrachloride. These data give the following series of free-energy equations:

$$
\begin{array}{lll}
2 \mathrm{Cl}_{2}(\mathrm{~g})=2 \mathrm{Cl}_{2}(\mathrm{aq}) & \Delta F_{273.16}^{\circ}= & 2.050 \text { kcal } \\
2 \mathrm{Cl}_{2}(\mathrm{aq})+2 \mathrm{H}_{2} \mathrm{O}(\mathrm{liq})= & \\
2 \mathrm{HCl}(\mathrm{aq})+2 \mathrm{HClO}(\mathrm{aq}) & \Delta F_{273.16}^{\circ}= & 9.510 \\
2 \mathrm{HClO}(\mathrm{aq})=\mathrm{Cl}_{2} \mathrm{O}(\mathrm{aq})+\mathrm{H}_{2} \mathrm{O}(\mathrm{liq}) & \Delta F_{273.16}^{\circ}= & 3.063 \\
\mathrm{Cl}_{2} \mathrm{O}(\mathrm{aq})=\mathrm{Cl}_{2} \mathrm{O}\left(\mathrm{in} \mathrm{CCl}_{4}\right) & \Delta F_{273.16}^{\circ}=-0.433 \\
\mathrm{Cl}_{2} \mathrm{O}\left(\mathrm{in} \mathrm{CCl}_{4}\right)=\mathrm{Cl}_{2} \mathrm{O}(\mathrm{g}) & \Delta F_{273.16}^{\circ}= & 1.344 \\
2 \mathrm{HCl}(\mathrm{aq})=\mathrm{H}_{2}(\mathrm{~g})+\mathrm{Cl}_{2}(\mathrm{~g}) & \Delta F_{273.16}^{\circ}=64.072 \\
\mathrm{H}_{2}(\mathrm{~g})+1 / 2 \mathrm{O}_{2}(\mathrm{~g})=\mathrm{H}_{2} \mathrm{O}(\mathrm{liq}) & \Delta F_{273.13}^{\circ}=-57.657
\end{array}
$$

$$
\mathrm{Cl}_{2}(\mathrm{~g})+1 / 2 \mathrm{O}_{2}(\mathrm{~g})=\mathrm{Cl}_{3} \mathrm{O}(\mathrm{g})
$$

From the thermodynamic functions $\Delta S_{273.16}^{\circ}=$ $-14.06 \mathrm{cal} / \mathrm{deg}$ mole for this reaction. Combining these gives $\Delta H f_{273.16}^{\circ} \mathrm{Cl}_{\varepsilon} \mathrm{O}(\mathrm{g})=18.10 \mathrm{kcal}$; corrected to $298.16^{\circ} \mathrm{K}$, this becomes $18.08 \mathrm{kcal}$.

Thomsen [78] measured the heat of hydrolysis of $\mathrm{Cl}_{2} \mathrm{O}(\mathrm{g})$ to $\mathrm{HClO}(\mathrm{aq})$ as $\Delta H_{291}=-9.44 \mathrm{kcal}$, which becomes $-9.51 \mathrm{kcal}$ at $298.16^{\circ} \mathrm{K}$. He also measured the heat of the reaction of chlorine gas with aqueous sodium hydroxide to give an aqueous solution of sodium chloride and sodium hypochlorite, and the heats of neutralization of hydrochloric and hypochlorous acids with aqueous sodium hydroxide. Combining these data gives $\Delta H f_{298.13}^{\circ} \mathrm{Cl}_{2} \mathrm{O}(\mathrm{g})=18.3$ keal.
Wallace and Goodeve [69] obtained the heat of explosion of $\mathrm{Cl}_{2} \mathrm{O}(\mathrm{g})$; their data give $\Delta H f_{298.16}^{\circ} \mathrm{Cl}_{2} \mathrm{O}$ $(\mathrm{g})=21.4$ kcal. Günther and Wekua [79] also measured the heat of explosion; their data give $\Delta H f_{298.16}^{\circ} \mathrm{Cl}_{2} \mathrm{O}(\mathrm{g})=24.7 \mathrm{kcal}$.

For the "best" value we have taken

$$
\begin{gathered}
\mathrm{Cl}_{2}(\mathrm{~g})+1 / 2 \mathrm{O}_{2}(\mathrm{~g})=\mathrm{Cl}_{2} \mathrm{O}(\mathrm{g}) \\
\Delta H^{\circ}{ }_{298}{ }_{16}=18.1 \pm 0.3 \mathrm{kcal} .
\end{gathered}
$$

CIF (g). Wicke and Friz [56, 80] measured the heat evolved in the adiabatic explosion of $\mathrm{Cl}_{2}-\mathrm{F}_{2}$ mixtures; their results give $\Delta H f_{0}^{\circ} \mathrm{ClF}(\mathrm{g})=-11.7$ 
kcal. Schmitz and Schumacher [81] measured the heat of the reaction $\mathrm{NaCl}$ (c) $+\mathrm{ClF} \quad(\mathrm{g})=\mathrm{NaF}$ (c) $+\mathrm{Cl}_{\text {. }}$ (g) at $18^{\circ} \mathrm{C}$. Their value of $\Delta H,-24.5$ kcal, gives $\Delta H f_{0}^{\circ} \mathrm{ClF}(\mathrm{g})=-13.3 \mathrm{kcal}$. They also measured the heat of the reaction $1 / 2 \mathrm{~F}_{2}(\mathrm{~g})+\mathrm{NaCl}$ (c) $=\mathrm{NaF}$ (c) $+1 / 2 \mathrm{Cl}_{2}(\mathrm{~g})$; if this heat, $\Delta H=-39.5$ keal, is combined with that given above for the reaction of $\mathrm{ClF}$, then $\Delta H f_{0}^{\circ} \mathrm{ClF}(\mathrm{g})=-15.0 \mathrm{kcal}$. Schmitz and Schumacher [82], Schumacher, Schmitz, and Brodersen [83], and Warhaftig [84] obtained the dissociation limit of ClF (g) from spectroscopic measurements. Two combinations of dissociation products are possible: $\mathrm{Cl}\left({ }^{2} \mathrm{P}_{1 / 2}\right)+\mathrm{F}\left({ }^{2} \mathrm{P}_{3 / 2}\right)$ or $\mathrm{Cl}\left({ }^{2} \mathrm{P}_{3 / 2}\right)+$ $\mathrm{F}\left({ }^{2} \mathrm{P}_{1 / 2}\right)$. After reducing the measured dissociation energies to the atomic ground states, using energies from Moore [6], the values in table 5 are obtained. These data give $\Delta H f_{0}^{\circ} \mathrm{ClF}(\mathrm{g})=-12.0$ or -13.4 kcal. The data for $\mathrm{IBr}(\mathrm{g})$ and $\mathrm{ICl}(\mathrm{g})$ (see below) show that in these molecules the lighter atom is in the excited ${ }^{2} \mathrm{P}_{1 / 2}$ state; by analogy the fluorine should be in the excited state. This choice also agrees somewhat better with the data for $\mathrm{ClF}_{3}(\mathrm{~g})$. (See also, the discussion by Slutsky and Bauer [53].) The "best" value appears to be

$$
\begin{gathered}
1 / 2 \mathrm{Cl}_{2}(\mathrm{~g})+1 / 2 \mathrm{~F}_{2}(\mathrm{~g})=\mathrm{ClF}(\mathrm{g}) \\
\Delta H_{0}^{\circ}=-13.4 \pm 0.5 \text { kcal. }
\end{gathered}
$$

\begin{tabular}{|c|c|c|}
\hline \multirow{2}{*}{ Observer } & \multicolumn{2}{|c|}{$D_{0}^{\circ}, \mathrm{keal}$, if products of dissociation are- } \\
\hline & $\mathrm{Cl}\left({ }^{2} \mathrm{P}_{1 / 2}\right)+\mathrm{F}\left({ }^{2} \mathrm{P}_{3 / 2}\right)$ & $\mathrm{Cl}\left({ }^{2} \mathrm{P}_{3} 2\right)+\mathrm{F}\left({ }^{2} \mathrm{P}_{1 / 2}\right)$ \\
\hline $\begin{array}{l}\text { Schmitz and Schu- } \\
\text { macher [82] } \\
\text { Schumacher, Schmitz, } \\
\text { and Brodersen [83] } \\
\text { Warhaftig [84] }\end{array}$ & $\begin{array}{l}59.00 \\
\\
58.97 \\
58.96\end{array}$ & $\begin{array}{l}60.37 \\
60.34 \\
60.33\end{array}$ \\
\hline
\end{tabular}

TABLE 5. Dissociation energy of $\mathrm{ClF}$

Ruff and Laass [85] measured the heat of reduction of ClF (g) by hydrogen. The data they report are self-consistent, but give a much too negative value of $-27.6 \mathrm{kcal}$ for $\Delta H f_{0}^{\circ} \mathrm{ClF}(\mathrm{g})$.

$\mathbf{C I F}_{3}$ (g). Schmitz and Schumacher [86] reported three measurements of the equilibrium constant for the reaction $\mathrm{ClF}_{3}(\mathrm{~g})=\mathrm{ClF}(\mathrm{g})+\mathrm{F}_{2}(\mathrm{~g})$; their data give $\Delta H_{0}^{\circ}=24.50 \mathrm{kcal}$ for this reaction. Schäfer and Wicke [46] reported 13 measurements of the same equilibrium; their results as read from a graph give $\Delta H_{0}^{\circ}=24.6 \mathrm{kcal}$. The value $\Delta H_{0}^{\circ}=24.5 \mathrm{kcal}$ was selected for this reaction. Two possible values of $\Delta H f_{0}^{\circ} \mathrm{ClF}(\mathrm{g})$ may be combined with this value of $\Delta H_{0}^{\circ}$ to calculate the heat of formation of $\mathrm{ClF}_{3}$. If $\Delta H f_{0}^{\circ} \mathrm{ClF}(\mathrm{g})$ is taken as $-12.0 \mathrm{kcal}, \Delta H f_{0}^{\circ} \mathrm{ClF}_{3}$ $(\mathrm{g})=-36.5 \mathrm{kcal}$; if $\Delta H f_{0}^{\circ} \mathrm{ClF}(\mathrm{g})$ is $-13.4 \mathrm{kcal}$, the value for $\mathrm{ClF}_{3}$ becomes $-37.9 \mathrm{kcal}$.

Schmitz and Schumacher [81] also obtained, at $18^{\circ} \mathrm{C}$, for the reaction $\mathrm{ClF}_{3}(\mathrm{~g})+3 \mathrm{NaCl}(\mathrm{c})=3 \mathrm{NaF}$ (c) $+2 \mathrm{Cl}_{2}(\mathrm{~g}), \Delta H=-76.5 \mathrm{kcal}$. A number of different values of $\Delta H f_{0}^{\circ} \mathrm{ClF}_{3}(\mathrm{~g})$ can be calculated from this value, depending upon the auxiliary data used. If the heats of formation of $\mathrm{NaCl}$ and $\mathrm{NaF}$ are taken as the selected "best" values [1], $\Delta H f_{0}^{\circ} \mathrm{ClF}_{3}(\mathrm{~g})=$
-35.9 kcal. A second value can be obtained by using Schmitz and Schumacher's [81] data for the reaction, at $18^{\circ} \mathrm{C}, 1 / 2 \quad \mathrm{~F}_{2}(\mathrm{~g})+\mathrm{NaCl}$ (c) $=1 / 2 \mathrm{Cl}_{2}$ $(\mathrm{g})+\mathrm{NaF}(\mathrm{c}), \Delta H=-39.5 \mathrm{kcal}$, and the selected heat of formation of $\mathrm{NaCl}$. From these data we calculate $\Delta H f_{0}^{\circ} \mathrm{ClF}_{3}(\mathrm{~g})=-41.9 \mathrm{kcal}$. The third and fourth values are obtained by combining Schmitz and Schumacher's [81] data for the reaction ClF $(\mathrm{g})+\mathrm{NaCl}(\mathrm{c})=\mathrm{NaF}(\mathrm{c})+\mathrm{Cl}_{2}(\mathrm{~g}), \Delta H=-24.5 \mathrm{kcal}$ at $18^{\circ} \mathrm{C}$, with the data for the similar reaction with $\mathrm{ClF}_{3}$ given above, to get $\mathrm{ClF}_{3}(\mathrm{~g})+\mathrm{Cl}_{2}(\mathrm{~g})=3 \mathrm{ClF}$ $(\mathrm{g}), \Delta H=-3.0 \mathrm{kcal}$. Depending upon the value chosen for $\Delta H f_{0}^{\circ} \mathrm{ClF}(\mathrm{g}),-12.0$ or $-13.4 \mathrm{kcal}$, this gives $\Delta H f_{0}^{\circ} \mathrm{ClF}_{3}(\mathrm{~g})=-32.1$ or $-36.3 \mathrm{kcal}$, respectively.

The value most consistent with all of the data summarized above, and also with the data for ClF, seems to be that from the equilibrium measurements. We have selected as the "best" value

$$
\begin{gathered}
1 / 2 \mathrm{Cl}_{2}(\mathrm{~g})+3 / 2 \mathrm{~F}_{2}(\mathrm{~g})=\mathrm{ClF}_{3}(\mathrm{~g}) \\
\Delta H_{0}^{\circ}=-37.9 \pm 1.0 \mathrm{kcal} .
\end{gathered}
$$

Br (g). Herzberg [14] and Gaydon [63] give the dissociation energy $D_{0}^{\circ}\left(\mathrm{Br}_{2}\right)$ as $1.971 \mathrm{ev}$, or 45.456 kcal. This was used to obtain the selected value

$$
\begin{gathered}
1 / 2 \mathrm{Br}_{2}(\mathrm{~g})=\mathrm{Br}(\mathrm{g}) \\
\Delta H_{0}^{\circ}=22.73 \pm 0.05 \mathrm{kcal} .
\end{gathered}
$$

Vapor-density measurements have been made at high temperatures by von Wartenberg and Henglein $[64,65]\left(833^{\circ}\right.$ to $\left.1,003^{\circ} \mathrm{K}\right)$, Perman and Atkinson $[87,88]\left(1,175^{\circ}\right.$ to $\left.1,330^{\circ} \mathrm{K}\right)$, Cramer [87] $\left(1,056^{\circ}\right.$ to $1,558^{\circ} \mathrm{K}$ ), and Bodenstein and Schmidt [126] $\left(1,495^{\circ} \mathrm{K}\right)$. Their data give, respectively, 46.33, $44.92,46.04$, and 45.20 keal for $D_{0}^{\circ}\left(\mathrm{Br}_{2}\right)$, in agreement with the spectroscopic value within the estimated uncertainty of $\pm 1.0 \mathrm{kcal}$. DeVries and Rodebush [90] have also reported data in the range $923^{\circ}$ to $1,173^{\circ} \mathrm{K}$; their data give values of $D_{0}^{\circ}$, approximately 5 keal more positive, which show a pronounced trend with temperature.

BrF (g). Durie [19] has obtained the spectroscopic dissociation limit of $\mathrm{BrF}$ as $21,190 \mathrm{~cm}^{-1}$. As in the case of ClF, there are two possible sets of dissociation products: $\operatorname{Br}\left({ }^{2} \mathrm{P}_{1 / 2}\right)+\mathrm{F}\left({ }^{2} \mathrm{P}_{3 / 2}\right)$ or $\operatorname{Br}\left({ }^{2} \mathrm{P}_{3 / 2}\right)$ $+\mathrm{F}\left({ }^{2} \mathrm{P}_{1 / 2}\right)$. Correcting the observed dissociation limit to the ground states of the atoms gives two values for $D_{0}^{\circ}(\mathrm{BrF})$; if fluorine is the excited atom $\left(\mathrm{F}\left({ }^{2} \mathrm{P}_{1 / 2}\right)\right), \quad D_{0}^{\circ}=59.42$ kcal; if bromine is excited, $D_{0}^{\circ}=50.04$ keal. By analogy with CIF and IF (see below) the "best" value seems to be the higher one: this gives

$$
\begin{gathered}
1 / 2 \mathrm{Br}_{2}(\mathrm{~g})+1 / 2 \mathrm{~F}_{2}(\mathrm{~g})=\mathrm{BrF}(\mathrm{g}) \\
\Delta H_{0}^{\circ}=-18.3 \pm 0.5 \mathrm{kcal} .
\end{gathered}
$$


$\mathbf{B r F}_{5}$ (g). Experimental data leading to a heat of formation for $\mathrm{BrF}_{5}(\mathrm{~g})$ are not available. Slutsky and Bauer [53] have estimated average bond energies that give

$$
\begin{gathered}
1 / 2 \mathrm{Br}_{2}(\mathrm{~g})+5 / 2 \mathrm{~F}_{2}(\mathrm{~g})=\mathrm{BrF}_{5}(\mathrm{~g}) \\
\Delta H_{0}^{\circ}=-122 \pm 10 \mathrm{kcal} .
\end{gathered}
$$

$\mathrm{BrCl}$ (g). The equilibrium $2 \mathrm{BrCl}(\mathrm{g})=\mathrm{Br}_{2}(\mathrm{~g})+$ $\mathrm{Cl}_{2}(\mathrm{~g})$ has been studied by several investigators; their results are summarized in table 6 . The average of all, except Jost's, gives

$$
\begin{gathered}
1 / 2 \mathrm{Br}_{2}(\mathrm{~g})+1 / 2 \mathrm{Cl}_{2}(\mathrm{~g})=\mathrm{BrCl}(\mathrm{g}) \\
\Delta H_{0}^{\circ}=-0.20 \pm 0.05 \mathrm{kcal} .
\end{gathered}
$$

TABLE 6. Heat of dissociation of $\mathrm{BrCl}(\mathrm{g})$

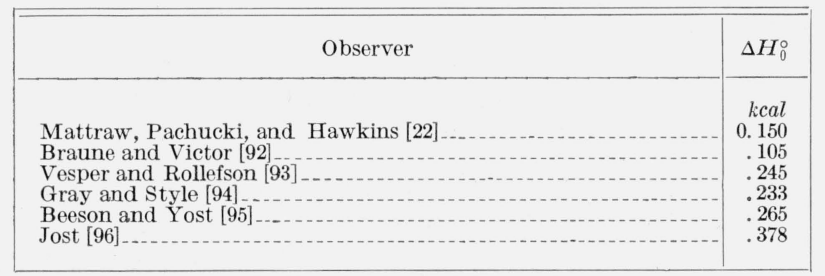

I (g). Gaydon [63] and Herzberg [14] give the dissociation limit of $\mathrm{I}_{2}$ to $\mathrm{I}\left({ }^{2} \mathrm{P}_{1 / 2}\right)+\mathrm{I}\left({ }^{2} \mathrm{P}_{3 / 2}\right)$ as 20,037 $\mathrm{cm}^{-1}$. When corrected to the ground state this becomes $12,434 \mathrm{~cm}^{-1}$, or $35.543 \mathrm{kcal}$, for $D_{0}^{\circ}\left(\mathrm{I}_{2}\right)$. High-temperature gas-density measurements have been made by Braune and Ramstetter [87] $\left(915^{\circ}\right.$ to $\left.1,385^{\circ} \mathrm{K}\right)$, Starck and Bodenstein [98] $\left(1,073^{\circ}\right.$ to $\left.1,473^{\circ} \mathrm{K}\right), \mathrm{DeV}$ ries and Rodebush [90] $\left(732^{\circ}\right.$ to $898^{\circ}$ $\mathrm{K})$, Bodenstein and Schmidt [126] $\left(1,495^{\circ} \mathrm{K}\right)$, and Perlman and Rollefson [99] (872 ${ }^{\circ}$ to $\left.1,274^{\circ} \mathrm{K}\right)$. Their data give values of $D_{0}^{\circ}\left(\mathrm{I}_{2}\right)$ of $35.95,35.49$, $35.68,35.17$, and $35.534 \mathrm{kcal}$, respectively. We have taken $35.538 \mathrm{kcal}$ as the "best" value for $D_{0}^{\circ}\left(\mathrm{I}_{2}\right)$; this is the average of the values from the very careful work of Perlman and Rollefson and from the spectroscopic data. Consequently,

$$
\begin{gathered}
1 / 2 \mathrm{I}_{2}(\mathrm{~g})=\mathrm{I}(\mathrm{g}) \\
\Delta H_{0}^{\circ}=17.77 \pm 0.03 \mathrm{kcal}
\end{gathered}
$$

IF (g). Durie [19] has obtained the dissociation limit of IF as $23,570 \mathrm{~cm}^{-1}$. As in the case of the other interhalogen compounds, two sets of dissociation products are possible: $\mathrm{I}\left({ }^{2} \mathrm{P}_{1 / 2}\right)+\mathrm{F}\left({ }^{2} \mathrm{P}_{3 / 2}\right)$ or $\mathrm{I}\left({ }^{2} \mathrm{P}_{3 / 2}\right)+$ $\mathrm{F}\left({ }^{2} \mathrm{P}_{1 / 2}\right)$. When corrected to the normal atoms, this limit gives $D_{0}^{\circ}$ (IF) as 45.64 or $66.22 \mathrm{kcal}$, respectively. Durie and Gaydon [91], arguing from the much higher stability of $\mathrm{IF}_{5}$, as compared with $\mathrm{IF}$, favored the lower value. However, Slutsky and Bauer [53] have pointed out a numerical error in their calculations, which removes the chief support for the low value, and presented additional evidence favoring the high value. The data for $\mathrm{ICl}(\mathrm{g})$ and
$\mathrm{IBr}(\mathrm{g})$ also support this value. At present the "best" value seems to be the higher one. This gives

$$
\begin{gathered}
1 / 2 \mathrm{I}_{2}(\mathrm{~g})+1 / 2 \mathrm{~F}_{2}(\mathrm{~g})=\mathrm{IF}(\mathrm{g}) \\
\Delta H_{0}^{\circ}=-30.0 \pm 0.5 \text { keal. }
\end{gathered}
$$

$\mathbf{I F}_{5}(\mathbf{g})$. Woolf [100] measured the heat of hydrolysis of liquid $\mathrm{IF}_{5}$ :

$$
\begin{gathered}
\mathrm{IF}_{5} \text { (liq) }+3 \mathrm{H}_{2} \mathrm{O} \text { (liq) }=5 \mathrm{HF}\left(250 \mathrm{H}_{2} \mathrm{O}\right)+\mathrm{HIO}_{3} \\
\left(1,250 \mathrm{H}_{2} \mathrm{O}\right) \\
\Delta H_{29_{1}}=-22.05 \text { kcal. }
\end{gathered}
$$

Correcting this to $298^{\circ} \mathrm{K}$ gives $\Delta H_{298.16}=-23.55$ keal. From this, $\Delta H f_{298.16}^{\circ} \mathrm{IF}_{5}$ (liq) $=-212.3 \mathrm{kcal}$. Woolf also measured the alkaline heat of hydrolysis:

$\mathrm{IF}_{5}(\mathrm{liq})+6 \mathrm{KOH}\left(220 \mathrm{H}_{2} \mathrm{O}\right)=$

$$
\begin{gathered}
5 \mathrm{KF}\left(250 \mathrm{H}_{2} \mathrm{O}\right)+\mathrm{KIO}_{3}\left(1,250 \mathrm{H}_{2} \mathrm{O}\right)+3 \mathrm{H}_{2} \mathrm{O} \text { (liq) } \\
\Delta \mathrm{H}_{291}=-118.9 \mathrm{kcal} ;
\end{gathered}
$$

at $298^{\circ} \mathrm{K}$ this becomes $-118.7 \mathrm{kcal}$. From this, $\Delta H f_{298.16}^{\circ} \quad \mathrm{IF}_{5} \quad$ (liq) $=-212.5$ kcal. The average, $-212.4 \pm 1.5 \mathrm{kcal}$, was taken as the "best" value.

The heat of vaporization of $\mathrm{IF}_{5}$ (liq) at $10^{\circ} \mathrm{C}$ is $10.12 \mathrm{kcal}[1]$; correction to $25^{\circ} \mathrm{C}$ makes this 9.85 kcal. When added to the value for the liquid this gives

$$
\begin{gathered}
1 / 2 \mathrm{I}_{2}(\mathrm{~g})+5 / 2 \mathrm{~F}_{2}(\mathrm{~g})=\mathrm{IF}_{5}(\mathrm{~g}) \\
\Delta H^{\circ}{ }_{298.16}=-202.6 \pm 1.6 \mathrm{kcal} .
\end{gathered}
$$

$\mathbf{I F}_{7}(\mathbf{g})$. Bernstein and Katz [101] have measured the dissociation equilibrium of $\mathrm{IF}_{7}(\mathrm{~g})$ between $450^{\circ}$ and $550^{\circ} \mathrm{K}$. Their data give

$$
\begin{gathered}
\mathrm{IF}_{7}(\mathrm{~g})=\mathrm{IF}_{5}(\mathrm{~g})+\mathrm{F}_{2}(\mathrm{~g}) \\
\Delta H_{0}^{\circ}=28.0 \pm 0.5 \mathrm{kcal} \\
\Delta H_{298.16}^{\circ}=29.1 \pm 0.5 \mathrm{kcal} .
\end{gathered}
$$

Combining this with $\Delta H f_{298.16}^{\circ} \mathrm{IF}_{5}$ (g) gives

$$
\begin{gathered}
1 / 2 \mathrm{I}_{2}(\mathrm{~g})+7 / 2 \mathrm{~F}_{2}(\mathrm{~g})=\mathrm{IF}_{7}(\mathrm{~g}) \\
\Delta H_{298.16}^{\mathrm{c}}=-231.7 \pm 1.8 \mathrm{kcal} .
\end{gathered}
$$

ICI $(\boldsymbol{g})$. Brown and Gibson [102] obtained the dissociation limits of $\mathrm{ICl}$ going to both $\mathrm{I}\left({ }^{2} \mathrm{P}_{3 / 2}\right)+$ $\mathrm{Cl}\left({ }^{2} \mathrm{P}_{3 / 2}\right)$ and $\mathrm{I}\left({ }^{2} \mathrm{P}_{3 / 2}\right)+\mathrm{Cl}\left({ }^{2} \mathrm{P}_{1 / 2}\right)$. Their data give $\mathrm{D}_{0}^{\circ}$ (ICl) as 49.64 and $49.65 \mathrm{kcal}$, respectively; from these $\Delta H f_{0}^{\circ}$ ICl $(\mathrm{g})$ is -3.33 and $-3.34 \mathrm{kcal}$. McMorris and Yost [103] measured the dissociation equilibrium of $\mathrm{ICl}(\mathrm{g})$; their data give $\Delta H f_{0}^{\circ} \mathrm{ICl}(\mathrm{g})=$ -3.32 kcal. The average was taken as the "best" value:

$$
\begin{gathered}
1 / 2 \mathrm{I}_{2}(\mathrm{~g})+1 / 2 \mathrm{Cl}_{2}(\mathrm{~g})=\mathrm{ICl}(\mathrm{g}) \\
\Delta H_{0}^{\circ}=-3.33 \pm 0.05 \mathrm{kcal} .
\end{gathered}
$$


IBr $(\boldsymbol{g})$. McMorris and Yost [104] measured the dissociation equilibrium of $\mathrm{IBr}(\mathrm{g})$; their data give $\Delta H f_{0}^{\circ}=-1.42 \mathrm{kcal}$. Brown [105] obtained the dissociation limits of $\mathrm{IBr}$ going to $\mathrm{I}\left({ }^{2} \mathrm{P}_{3 / 2}\right)+\mathrm{Br}\left({ }^{2} \mathrm{P}_{1 / 2}\right)$ and to $\mathrm{I}\left({ }^{2} \mathrm{P}_{3 / 2}\right)+\mathrm{Br}\left({ }^{2} \mathrm{P}_{3 / 2}\right)$; both limits give $D_{0}^{\circ}(\mathrm{IBr})=$ $41.91 \mathrm{kcal}$ and $\Delta H f_{0}^{\circ} \mathrm{IBr}(\mathrm{g})=-1.41 \mathrm{kcal}$.

$$
\begin{gathered}
1 / 2 \mathrm{I}_{2}(\mathrm{~g})+1 / 2 \mathrm{Br}_{2}(\mathrm{~g})=\mathrm{IBr}(\mathrm{g}) \\
\Delta H_{0}^{\circ}=-1.41 \pm 0.06 \text { kcal. }
\end{gathered}
$$

Bodenstein and Schmidt [126] obtained $\Delta H f_{0}^{\circ} \mathrm{IBr}$ $(\mathrm{g})=-1.48 \mathrm{kcal}$ from gas-density measurements at $1,495^{\circ} \mathrm{K}$; Müller [127] calculated -1.73 kcal from his kinetic studies. The agreement between the equilibrium data and the spectroscopic dissociation limits, in which the lighter atom is in the excited state in the normal dissociation process, furnishes additional support for the selection of the dissociation products assumed for $\mathrm{ClF}, \mathrm{BrF}$, and IF.

\section{Discussion}

The thermodynamic functions calculated, as outlined in section 3 , are given in tables 7 to 27 . The uncertainties in the functions are estimated to be not more than about 20 in the last figure given; the heat contents, $H^{\circ}-H_{0}^{\circ}$, however, as quantities derived directly from the heat-content functions, may retain one additional significant figure.

Tables 7 to 27 also include values of the heat of formation, $\Delta H f^{\circ}$, free energy of formation, $\Delta F f^{\circ}$, and logarithm of the equilibrium constant of formation, $\log K f$, as a function of temperature. These were calculated from the relations

$$
\begin{aligned}
\Delta H f^{\circ} & =\Delta H f_{0}^{\circ}+\Delta\left(H^{\circ}-H_{0}^{\circ}\right) \\
\Delta F f^{\circ} & =\Delta H f_{0}^{\circ}+T \Delta\left[\left(F^{\circ}-H_{0}^{\circ}\right) / T\right] \\
\log _{10} K f & =-\Delta F f^{\circ} / 4.57567 T .
\end{aligned}
$$

The values of $\Delta H f_{0}^{\circ}$ used were those selected in section 4 ; where $\Delta H_{298.16}^{\circ}$ has been selected, this was corrected to $\Delta H f_{0}^{\circ}$ for the calculations. The values of $\Delta H f^{\circ}$ and $\Delta F f^{\circ}$ are often given to more significant figures than the basic value at $0^{\circ} \mathrm{K}$ or $298.16^{\circ} \mathrm{K}$ to retain differences that are more precise than the basic value. As a derived quantity, $\log K f$ is given to one more decimal place than is $\Delta F f^{\circ}$.

Cole, Farber, and Elverum [106], Murphy and Vance [107], and Butkov and Rozenbaum [108] have calculated the thermodynamic functions for $\mathrm{F}(\mathrm{g})$; our calculations agree closely with those of Cole, Farber, and Elverum, and of Murphy and Vance, when allowance is made for the different values used for the fundamental constants. They have also calculated the thermodynamic functions for $\mathrm{F}_{2}(\mathrm{~g})$. Because of different choices for molecular and fundamental constants, none of these calculations agrees exactly with the present one. Recently $\mathrm{Hu}$, White, and Johnston [109] have calculated the entropy of $\mathrm{F}_{2}(\mathrm{~g})$ at $85.02^{\circ} \mathrm{K}$ from low-temperature heat- capacity data and heats of transition, fusion, and vaporization; their value, $39.58 \pm 0.16 \mathrm{cal} / \mathrm{deg}$ mole, agrees very closely with one calculated from the data used in the present calculation, $39.57 \pm 0.03 \mathrm{cal} / \mathrm{deg}$ mole.

Potter [110] has calculated thermodynamic functions for $\mathrm{F}_{2} \mathrm{O}(\mathrm{g})$, using a different frequency assignment. His values differ from ours and have a different temperature dependence.

Giauque and Overstreet [111] have calculated the free-energy function for $\mathrm{Cl}(\mathrm{g})$, using fundamental constants from the International Critical Tables; when revised to the constants used in this paper their values agree with ours. Giauque and Overstreet also calculated the free-energy functions for $\mathrm{Cl}_{2}$ (g) by a semidirect summation method. Their values, as corrected to new constants [113] by Sherman and Giauque [112], agree with the present results. Giauque and Powell [114] calculated the entropy of $\mathrm{Cl}_{2}$ (g) from low-temperature calorimetric data to be $51.56 \pm 0.10 \mathrm{cal} / \mathrm{deg}$ mole at $239.05^{\circ} \mathrm{K}$; the present calculations give $51.54 \pm 0.03 \mathrm{cal} / \mathrm{deg}$ mole.

Thermodynamic functions for $\mathrm{ClF}(\mathrm{g})$ were calculated by Schäfer and Wicke [46], using the rigid rotator-harmonic oscillator approximation, and by Potter [110] (revised by Cole and Elverum [115] for new fundamental constants). When converted to the same fundamental constants used here, the latter calculations agree with the present ones.

Previous calculations of the thermodynamic functions for $\mathrm{ClF}_{3}$ (g) by Schäfer and Wicke [46] and Scheer [116] were based upon structural parameters and frequency assignments for the incorrect pyramidal structures.

Grisard, Bernhardt, and Oliver [117] measured the heat capacity of solid and liquid $\mathrm{ClF}_{3}$ from $14^{\circ}$ to $278^{\circ} \mathrm{K}$ and the vapor pressure of the liquid from $226^{\circ}$ to $303^{\circ} \mathrm{K}$. The calculation of the entropy of the gas from these data is complicated by the presence of the dimer $\left(\mathrm{ClF}_{3}\right)_{2}$ in the vapor. The data of Schmitz and Schumacher $\lceil 123\rceil$ on the monomer-dimer equilibrium were used to obtain the partial pressure of the monomer for each reported total pressure. From a $\log P-1 / T$ plot of these partial pressures the normal boiling point of monomeric $\mathrm{ClF}_{3}$ was obtained as $285.74^{\circ} \mathrm{K}$. Calculation of the heat of vaporization from the vapor pressure data by use of the Clapeyron equation requires the molar volumes of the gas and liquid. The volume of the gas was obtained from the Berthelot equation of state, using the critical constants estimated by Grisard, Bernhardt, and Oliver. The liquid volume was taken from the data of Banks and Rudge [124]. With $d P / d T$ obtained from the slope of the monomer vapor-pressure curve, these data gave $6,490 \mathrm{cal} / \mathrm{mole}$ for the heat of vaporization of $\mathrm{ClF}_{3}$ at its boiling point and an entropy of vaporization of 22.71 $\mathrm{cal} / \mathrm{deg}$ mole.

The entropy of liquid $\mathrm{ClF}_{3}, 43.74 \mathrm{cal} / \mathrm{deg}$ mole, was obtained by correcting the value given by Grisard, Bernhardt, and Oliver at $284.91^{\circ} \mathrm{K}$ to the boiling point $285.74^{\circ} \mathrm{K}$. The entrophy change in going from the real to the ideal gas was calculated 
from the Berthelot equation to be $0.11 \mathrm{cal} / \mathrm{deg}$ mole.

The entropy of $\mathrm{ClF}_{3}$ as an ideal gas at $285.74^{\circ} \mathrm{K}$ and $1 \mathrm{~atm}$ calculated from these data is $66.56 \mathrm{cal} / \mathrm{deg}$ mole. The value calculated statistically is 67.38 cal/deg mole. The reason for the difference is not known at present. The vibrational frequency assignment used is not certain and may be in error; however, it seems to be consistent with all the available spectroscopic data. (cf. Weber and Ferigle [1181.) On the other hand, Burbank and Bensey [125] have obtained some evidence that there is a random arrangement within the crystal that would lead to a residual entropy in the solid at $0^{\circ} \mathrm{K}$.

Gordon and Barnes [119] and Zeise [120] have calculated the functions for $\mathrm{Br}_{2}(\mathrm{~g})$. The more precise calculations of Gordon and Barnes, when converted to the new fundamental constants, agree with the present ones within $0.005 \mathrm{cal} / \mathrm{deg}$ mole.

The thermodynamic functions for $\mathrm{BrF}(\mathrm{g})$ and $\mathrm{BrCl}(\mathrm{g})$ have been calculated by Cole and Elverum [115]. Different choices of molecular constants, based in part upon more recent data, lead to small differences between the present calculations and theirs.

Stephenson and Jones [48] have calculated the functions for $\mathrm{BrF}_{5}(\mathrm{~g})$; as they assumed different molecular dimensions, their values of $-\left(F^{\circ}-H_{0}^{\circ}\right) / T$ and $S^{\circ}$ should differ from the present ones by a con- stant amount; this is nearly true. Their value for the free-energy function at $1,000^{\circ} \mathrm{K}$ is in error.

Murphy [121] and Zeise [122] have calculated free-energy functions for I (g); Murphy's values, corrected to the new constants, agree with the present ones. They have also calculated the free-energy function for $\mathrm{I}_{2}(\mathrm{~g})$; again, Murphy's calculations agree.

Cole and Elverum. $\lceil 115\rceil$ have calculated the functions for IF $(\mathrm{g})$. Their tabulated values of - $\left(F^{\circ}-H_{0}^{\circ}\right) / T$ are seriously in error for some reason; their other functions are in good agreement with the present ones.

Cole and Elverum also calculated the functions for ICl $(\mathrm{g})$ and $\mathrm{IBr}(\mathrm{g})$; Zeise $\lceil 120\rceil$ has calculated freeenergy functions for $\mathrm{IBr}(\mathrm{g})$. The calculations, corrected for constants, of Cole and Elverum agree with ours.

Gaydon has recently [128] revised many of his previous selections $[63\rceil$ of the values of gaseous diatomic dissociation energies. These values differ in part from those selected here. Because of a different choice of decomposition products, the values of $D_{0}^{\circ}$ that Gaydon selects for $\mathrm{ClF}, \mathrm{BrF}$, and IF differ from ours; this is discussed under the individual compounds. The other difference is for $\mathrm{BrCl}$; in this case Gaydon does not give details sufficient to locate the source of the discrepancy.

TABLE 7. Thermodynamic properties of $\mathrm{F}(\mathrm{g})$

\begin{tabular}{|c|c|c|c|c|c|c|c|c|}
\hline$T$ & $\left(F^{\circ}-H_{0}^{\circ}\right) / T$ & $\left(H^{\circ}-H_{0}^{\circ}\right) / T$ & $S^{a}$ & $H^{\circ}-H_{0}^{\circ}$ & $C_{p}^{\circ}$ & $\Delta H f^{\circ}$ & $\Delta F f^{\circ}$ & $\log K f$ \\
\hline $\begin{array}{l}{ }^{\circ} K \\
0 \\
250 \\
273.16 \\
298.16 \\
300 \\
400 \\
500\end{array}$ & $\begin{array}{c}\text { cal/deg mole } \\
0 \\
-31.7750 \\
-32.2352 \\
-32.6919 \\
-32.7241 \\
-34.2348 \\
-35.4123\end{array}$ & $\begin{array}{c}\text { cal/deg mole } \\
0 \\
5.1834 \\
5.2057 \\
5.2254 \\
5.2267 \\
5.2703 \\
5.2804\end{array}$ & $\begin{array}{c}\text { cal/deg mole } \\
0 \\
36.9584 \\
37.4409 \\
37.9173 \\
37.9508 \\
39.5051 \\
40.6927\end{array}$ & $\begin{array}{c}\text { cal/mole } \\
0 \\
1295.8 \\
1422.0 \\
1558.0 \\
1568.0 \\
2108.1 \\
2640.2\end{array}$ & $\begin{array}{c}\text { cal/deg mole } \\
0 \\
5.4454 \\
5.4452 \\
5.4365 \\
5.4355 \\
5.3612 \\
5.2819\end{array}$ & $\begin{array}{l}\text { kcal, mole } \\
18.4 \\
18.819 \\
18.861 \\
18.903 \\
18.906 \\
19.06 \\
19.19\end{array}$ & $\begin{array}{l}\text { kcal/mole } \\
18.4 \\
15.472 \\
15.161 \\
14.820 \\
14.794 \\
13.40 \\
11.97\end{array}$ & $\begin{array}{c}-13.5257 \\
-12.1298 \\
-10.8631 \\
-10.7779 \\
-7.322 \\
-5.232\end{array}$ \\
\hline $\begin{array}{r}600 \\
700 \\
800 \\
900 \\
1,000\end{array}$ & $\begin{array}{l}-36.3747 \\
-37.1871 \\
-37.8889 \\
-38.5063 \\
-39.0571\end{array}$ & $\begin{array}{l}\text { 5. } 2751 \\
\text { 5. } 2633 \\
\text { 5. } 2491 \\
\text { 5. } 2345 \\
\text { 5. } 2204\end{array}$ & $\begin{array}{l}41.6498 \\
42.4504 \\
43.1380 \\
43.7408 \\
44.2775\end{array}$ & $\begin{array}{l}3165.1 \\
3684.3 \\
4199.3 \\
4711.0 \\
5220.4\end{array}$ & $\begin{array}{l}\text { 5. } 2180 \\
\text { 5. } 1692 \\
\text { 5. } 1324 \\
\text { 5. } 1043 \\
\text { 5. } 0826\end{array}$ & $\begin{array}{l}19.30 \\
19.40 \\
19.48 \\
19.55 \\
19.62\end{array}$ & $\begin{array}{r}10.51 \\
9.04 \\
7.56 \\
6.06 \\
4.56\end{array}$ & $\begin{array}{l}-3.830 \\
-2.823 \\
-2.065 \\
-1.472 \\
-0.997\end{array}$ \\
\hline $\begin{array}{l}1,100 \\
1,200 \\
1,300 \\
1,400 \\
1,500\end{array}$ & $\begin{array}{l}-39.5540 \\
-40.0065 \\
-40.4218 \\
-40.8056 \\
-41.1622\end{array}$ & $\begin{array}{l}\text { 5. } 2070 \\
5.1946 \\
5.1832 \\
5.1727 \\
5.1631\end{array}$ & $\begin{array}{l}44.7610 \\
45.2011 \\
45.6050 \\
45.9783 \\
46.3253\end{array}$ & $\begin{array}{l}5727.7 \\
6233.5 \\
6738.2 \\
7241.8 \\
7744.6\end{array}$ & $\begin{array}{l}\text { 5. } 0655 \\
\text { 5. } 0519 \\
5.0409 \\
5.0319 \\
5.0244\end{array}$ & $\begin{array}{l}19.69 \\
19.75 \\
19.80 \\
19.86 \\
19.91\end{array}$ & $\begin{array}{r}3.05 \\
1.53 \\
0.01 \\
-1.51 \\
-3.04\end{array}$ & $\begin{array}{r}-.606 \\
-.280 \\
-.002 \\
.235 \\
.442\end{array}$ \\
\hline $\begin{array}{l}1,600 \\
1,700 \\
1,800 \\
1,900 \\
2,000\end{array}$ & $\begin{array}{l}-41.4951 \\
-41.8073 \\
-42.1012 \\
-42.3788 \\
-42.6419\end{array}$ & $\begin{array}{l}\text { 5. } 1542 \\
5.1460 \\
5.1385 \\
5.1316 \\
5.1252\end{array}$ & $\begin{array}{l}\text { 46. } 6493 \\
46.9533 \\
47.2397 \\
47.5104 \\
47.7671\end{array}$ & $\begin{array}{r}8246.7 \\
8748.2 \\
9249.3 \\
9750.0 \\
10250.4\end{array}$ & $\begin{array}{l}\text { 5. } 0182 \\
\text { 5. } 0129 \\
\text { 5. } 0084 \\
\text { 5. } 0045 \\
\text { 5. } 0012\end{array}$ & $\begin{array}{l}19.96 \\
20.00 \\
20.05 \\
20.09 \\
20.13\end{array}$ & $\begin{array}{r}-4.57 \\
-6.10 \\
-7.64 \\
-9.18 \\
-10.72\end{array}$ & $\begin{array}{r}.624 \\
.784 \\
.927 \\
1.056 \\
1.171\end{array}$ \\
\hline $\begin{array}{l}2,100 \\
2,200 \\
2,300 \\
2,400 \\
2,500\end{array}$ & $\begin{array}{l}-42.8918 \\
-43.1298 \\
-43.3571 \\
-43.5744 \\
-43.7826\end{array}$ & $\begin{array}{l}\text { 5. } 1192 \\
\text { 5. } 1136 \\
5.1084 \\
5.1036 \\
\text { 5. } 0991\end{array}$ & $\begin{array}{l}48.0110 \\
48.2434 \\
48.4655 \\
48.6780 \\
48.8817\end{array}$ & $\begin{array}{l}10750.3 \\
11249.9 \\
11749.3 \\
12248.6 \\
12747.8\end{array}$ & $\begin{array}{l}\text { 4. } 9983 \\
\text { 4. } 9958 \\
\text { 4. } 9936 \\
\text { 4. } 9916 \\
\text { 4. } 9898\end{array}$ & $\begin{array}{l}20.17 \\
20.21 \\
20.25 \\
20.29 \\
20.32\end{array}$ & $\begin{array}{l}-12.26 \\
-13.81 \\
-15.36 \\
-16.91 \\
-18.46\end{array}$ & $\begin{array}{l}\text { 1. } 276 \\
\text { 1. } 372 \\
\text { 1. } 459 \\
\text { 1. } 539 \\
\text { 1. } 613\end{array}$ \\
\hline $\begin{array}{l}2,750 \\
3,000 \\
3,250 \\
3,500 \\
3,750\end{array}$ & $\begin{array}{l}-44.2681 \\
-44.7105 \\
-45.1168 \\
-45.4925 \\
-45.8419\end{array}$ & $\begin{array}{l}5.0890 \\
5.0803 \\
5.0728 \\
5.0662 \\
5.0604\end{array}$ & $\begin{array}{l}49.3571 \\
49.7908 \\
50.1896 \\
50.5587 \\
50.9023\end{array}$ & $\begin{array}{l}13994.8 \\
15240.9 \\
16486.6 \\
17731.7 \\
18976.5\end{array}$ & $\begin{array}{l}\text { 4. } 9862 \\
\text { 4. } 9834 \\
\text { 4. } 9812 \\
\text { 4. } 9794 \\
\text { 4. } 9780\end{array}$ & $\begin{array}{c}20.41 \\
20.49 \\
\end{array}$ & $\begin{array}{l}-22.34 \\
-26.23 \\
-\end{array}$ & $\begin{array}{r}1.775 \\
1.911 \\
\end{array}$ \\
\hline $\begin{array}{l}4,000 \\
4,250 \\
4,500 \\
4,750 \\
5,000\end{array}$ & $\begin{array}{l}-46.1683 \\
-46.4746 \\
-46.7632 \\
-47.0359 \\
-47.2945\end{array}$ & $\begin{array}{l}\text { 5. } 0552 \\
5.0505 \\
5.0463 \\
5.0426 \\
5.0392\end{array}$ & $\begin{array}{l}\text { 51. } 2235 \\
51.5251 \\
51.8095 \\
52.0785 \\
52.3337\end{array}$ & $\begin{array}{l}20220.8 \\
21464.6 \\
22708.4 \\
23952.4 \\
25196.0\end{array}$ & $\begin{array}{l}\text { 4. } 9768 \\
\text { 4. } 9758 \\
\text { 4. } 9750 \\
\text { 4. } 9743 \\
\text { 4. } 9737\end{array}$ & - & - & - \\
\hline
\end{tabular}


TABLE 8. Thermodynamic properties of $\mathrm{F}_{2}$ (g)

\begin{tabular}{|c|c|c|c|c|c|c|c|c|}
\hline$T$ & $\left(F^{\circ}-H_{0}^{\circ}\right) / T$ & $\left(H^{\circ}-H_{0}^{\circ}\right) / T$ & $S^{\circ}$ & $H^{\circ}-H_{0}^{\circ}$ & $C_{p}^{\circ}$ & $\Delta H f^{\circ}$ & $\Delta F f^{\circ}$ & $\log K f$ \\
\hline $\begin{array}{l}{ }^{\circ} K \\
\quad 0 \\
250 \\
273.16 \\
298.16 \\
300 \\
400 \\
500\end{array}$ & $\begin{array}{c}\text { cal/deg mole } \\
0 \\
-40.129 \\
-40.755 \\
-41.371 \\
-41.415 \\
-43.472 \\
-45.103\end{array}$ & $\begin{array}{c}\text { cal/deg mole } \\
0 \\
7.017 \\
7.033 \\
7.076 \\
7.078 \\
7.233 \\
7.396\end{array}$ & $\begin{array}{c}\text { cal/deg mole } \\
0 \\
47.146 \\
47.788 \\
48.447 \\
48.493 \\
50.705 \\
52.499\end{array}$ & $\begin{array}{c}\text { cal/mole } \\
0 \\
1754.2 \\
1921.1 \\
2109.8 \\
2123.4 \\
2893.2 \\
3698.0\end{array}$ & $\begin{array}{c}\text { cal/deg mole } \\
0 \\
7.28 \\
7.38 \\
7.49 \\
7.49 \\
7.89 \\
8.19\end{array}$ & $\begin{array}{c}\text { kcal/mole } \\
0 \\
0 \\
0 \\
0 \\
0 \\
0 \\
0\end{array}$ & $\begin{array}{c}\text { kcal/mole } \\
0 \\
0 \\
0 \\
0 \\
0 \\
0 \\
0\end{array}$ & $\begin{array}{l}0 \\
0 \\
0 \\
0 \\
0 \\
0\end{array}$ \\
\hline $\begin{array}{r}600 \\
700 \\
800 \\
900 \\
1,000\end{array}$ & $\begin{array}{l}-46.464 \\
-47.639 \\
-48.672 \\
-49.598 \\
-50.435\end{array}$ & $\begin{array}{l}7.547 \\
7.682 \\
7.800 \\
7.903 \\
7.992\end{array}$ & $\begin{array}{l}54.011 \\
55.321 \\
56.472 \\
57.501 \\
58.427\end{array}$ & $\begin{array}{l}4528.2 \\
5377.4 \\
6240.0 \\
7112.7 \\
7992.0\end{array}$ & $\begin{array}{l}8.41 \\
8.56 \\
8.68 \\
8.77 \\
8.84\end{array}$ & $\begin{array}{l}0 \\
0 \\
0 \\
0 \\
0\end{array}$ & $\begin{array}{l}0 \\
0 \\
0 \\
0 \\
0\end{array}$ & $\begin{array}{l}0 \\
0 \\
0 \\
0 \\
0\end{array}$ \\
\hline $\begin{array}{l}1,100 \\
1,200 \\
1,300 \\
1,400 \\
1,500\end{array}$ & $\begin{array}{l}-51.200 \\
-51.905 \\
-52.559 \\
-53.171 \\
-53.744\end{array}$ & $\begin{array}{l}8.074 \\
8.144 \\
8.207 \\
8.265 \\
8.316\end{array}$ & $\begin{array}{l}59.274 \\
60.049 \\
60.766 \\
61.436 \\
62.060\end{array}$ & $\begin{array}{r}8881.4 \\
9772.8 \\
10669.1 \\
11571.0 \\
12474.0\end{array}$ & $\begin{array}{l}8.90 \\
8.94 \\
8.99 \\
9.02 \\
9.06\end{array}$ & $\begin{array}{l}0 \\
0 \\
0 \\
0 \\
0\end{array}$ & $\begin{array}{l}0 \\
0 \\
0 \\
0 \\
0\end{array}$ & $\begin{array}{l}0 \\
0 \\
0 \\
0 \\
0\end{array}$ \\
\hline $\begin{array}{l}1,600 \\
1,700 \\
1,800 \\
1,900 \\
2,000\end{array}$ & $\begin{array}{l}-54.280 \\
-54.789 \\
-55.272 \\
-55.729 \\
-56.164\end{array}$ & $\begin{array}{l}8.362 \\
8.406 \\
8.446 \\
8.483 \\
8.517\end{array}$ & $\begin{array}{l}\text { 62. } 642 \\
63.195 \\
63 .-18 \\
64.212 \\
\text { 64. } 681\end{array}$ & $\begin{array}{l}13379.2 \\
14290.2 \\
15202.8 \\
16117.7 \\
17034.0\end{array}$ & $\begin{array}{l}9.08 \\
9.11 \\
9.13 \\
9.15 \\
9.18\end{array}$ & $\begin{array}{l}0 \\
0 \\
0 \\
0 \\
0\end{array}$ & $\begin{array}{l}0 \\
0 \\
0 \\
0 \\
0\end{array}$ & $\begin{array}{l}0 \\
0 \\
0 \\
0 \\
0\end{array}$ \\
\hline $\begin{array}{l}2,100 \\
2,200 \\
2,300 \\
2,400 \\
2,500\end{array}$ & $\begin{array}{l}-56.581 \\
-56.979 \\
-57.360 \\
-57.728 \\
-58.082\end{array}$ & $\begin{array}{l}8.549 \\
8.579 \\
8.607 \\
8.634 \\
8.658\end{array}$ & $\begin{array}{l}65.130 \\
65.558 \\
65.967 \\
66.362 \\
66.740\end{array}$ & $\begin{array}{l}17952.9 \\
18873.8 \\
19796.1 \\
20721.6 \\
21645.6\end{array}$ & $\begin{array}{l}9.20 \\
9.22 \\
9.23 \\
9.25 \\
9.27\end{array}$ & $\begin{array}{l}0 \\
0 \\
0 \\
0 \\
0\end{array}$ & $\begin{array}{l}0 \\
0 \\
0 \\
0 \\
0\end{array}$ & $\begin{array}{l}0 \\
0 \\
0 \\
0 \\
0\end{array}$ \\
\hline $\begin{array}{l}2,750 \\
3,000\end{array}$ & $\begin{array}{l}-58.908 \\
-59.669\end{array}$ & $\begin{array}{l}8.715 \\
8.767\end{array}$ & $\begin{array}{l}67.623 \\
68.436\end{array}$ & $\begin{array}{l}23966.2 \\
26301.0\end{array}$ & $\begin{array}{l}9.31 \\
9.34\end{array}$ & $\begin{array}{l}0 \\
0\end{array}$ & $\begin{array}{l}0 \\
0\end{array}$ & $\begin{array}{l}0 \\
0\end{array}$ \\
\hline
\end{tabular}

TABLE 9. Thermodynamic properties of $\mathrm{F}_{2} \mathrm{O}(\mathrm{g})$

\begin{tabular}{|c|c|c|c|c|c|c|c|c|}
\hline$T$ & $\left(F^{\circ}-H_{0}^{\circ}\right) / T$ & $\left(H^{\circ}-H_{0}^{\circ}\right) / T$ & $S^{\circ}$ & $H^{\circ}-H_{0}^{\circ}$ & $C_{p}^{\circ}$ & $\Delta H f^{\circ}$ & $\Delta F f^{\circ}$ & $\log K f$ \\
\hline $\begin{array}{l}{ }^{\circ} K \\
0 \\
250 \\
273.16 \\
298.16 \\
300 \\
400 \\
500\end{array}$ & $\begin{array}{c}\text { cal/deg mole } \\
0 \\
-48.73 \\
-49.49 \\
-50.25 \\
-50.30 \\
-52.89 \\
-55.02\end{array}$ & $\begin{array}{c}\text { cal/deg mole } \\
0 \\
8.48 \\
8.60 \\
8.74 \\
8.75 \\
9.29 \\
9.78\end{array}$ & $\begin{array}{c}\text { calldeg mole } \\
0 \\
57.21 \\
58.09 \\
58.99 \\
59.05 \\
62.18 \\
64.80\end{array}$ & $\begin{array}{c}\text { cal/mole } \\
0 \\
2120 \\
2349 \\
2006 \\
2625 \\
3716 \\
4890\end{array}$ & $\begin{array}{c}\text { cal/deg mole } \\
0 \\
9.75 \\
10.05 \\
10.35 \\
10.38 \\
11.38 \\
12.06\end{array}$ & $\begin{array}{c}\text { kcal/mole } \\
8.14 \\
7.64 \\
7.62 \\
7.6 \\
7.60 \\
7.57 \\
7.57\end{array}$ & $\begin{array}{c}\text { kcal/mole } \\
8.14 \\
11.09 \\
11.41 \\
11.8 \\
11.79 \\
13.20 \\
14.60\end{array}$ & $\begin{array}{l}-9.698 \\
-9.132 \\
-8.65 \\
-8.589 \\
-7.209 \\
-6.382\end{array}$ \\
\hline $\begin{array}{r}600 \\
700 \\
800 \\
900 \\
1,000\end{array}$ & $\begin{array}{l}-53.84 \\
-58.44 \\
-59.87 \\
-61.16 \\
-62.35\end{array}$ & $\begin{array}{l}10.20 \\
10.56 \\
10.86 \\
11.11 \\
11.33\end{array}$ & $\begin{array}{l}66.04 \\
69.00 \\
70.73 \\
72.27 \\
73.68\end{array}$ & $\begin{array}{r}6120 \\
7392 \\
8688 \\
9999 \\
11330\end{array}$ & $\begin{array}{l}12.53 \\
12.84 \\
13.07 \\
13.23 \\
13.35\end{array}$ & $\begin{array}{l}7.59 \\
7.63 \\
7.66 \\
7.69 \\
7.73\end{array}$ & $\begin{array}{l}16.00 \\
17.40 \\
18.80 \\
20.19 \\
21.57\end{array}$ & $\begin{array}{l}-5.830 \\
-5.434 \\
-5.136 \\
-4.904 \\
-4.715\end{array}$ \\
\hline $\begin{array}{l}1,100 \\
1,200 \\
1,300 \\
1,400 \\
1,500\end{array}$ & $\begin{array}{l}-63.44 \\
-64.44 \\
-65.38 \\
-66.27 \\
-67.09\end{array}$ & $\begin{array}{l}11.52 \\
11.68 \\
11.82 \\
11.95 \\
12.06\end{array}$ & $\begin{array}{l}74.96 \\
76.12 \\
77.20 \\
78.22 \\
79.15\end{array}$ & $\begin{array}{l}12672 \\
14016 \\
15366 \\
16730 \\
18090\end{array}$ & $\begin{array}{l}13.44 \\
13.51 \\
13.57 \\
13.61 \\
13.65\end{array}$ & $\begin{array}{l}7.76 \\
7.79 \\
7.82 \\
7.85 \\
7.87\end{array}$ & $\begin{array}{l}22.95 \\
24.34 \\
25.72 \\
27.09 \\
28.47\end{array}$ & $\begin{array}{l}-4.560 \\
-4.432 \\
-4.325 \\
-4.230 \\
-4.149\end{array}$ \\
\hline
\end{tabular}


TABLE 10. Thermodynamic properties of $\mathrm{Cl}(\mathrm{g})$

\begin{tabular}{|c|c|c|c|c|c|c|c|c|}
\hline$T$ & $\left(F^{\circ}-H_{0}^{\circ}\right) / T$ & $\left(H^{\circ}-H_{0}^{\circ}\right) / T$ & $S^{\circ}$ & $H^{\circ}-H_{0}^{\circ}$ & $C_{p}^{\circ}$ & $\Delta H f^{\circ}$ & $\Delta F f^{\circ}$ & $\log K f$ \\
\hline $\begin{array}{l}{ }^{\circ} K \\
\quad 0 \\
250 \\
273.16 \\
298.16 \\
300 \\
400 \\
500\end{array}$ & $\begin{array}{c}\text { cal/deg mole } \\
0 \\
-33.5460 \\
-33.9984 \\
-34.4291 \\
-34.4600 \\
-35.9161 \\
-37.0605\end{array}$ & $\begin{array}{c}\text { cal/deg mole } \\
0 \\
4.9996 \\
5.0123 \\
5.0278 \\
5.0290 \\
5.0977 \\
5.1601\end{array}$ & $\begin{array}{c}\text { cal/deg mole } \\
0 \\
38.5456 \\
39.0107 \\
39.4569 \\
39.4890 \\
41.0138 \\
42.2296\end{array}$ & $\begin{array}{c}\text { cal/mole } \\
0 \\
1249.9 \\
1369.2 \\
1499.1 \\
1508.7 \\
2039.1 \\
2580.0\end{array}$ & $\begin{array}{c}\text { cal/deg mole } \\
0 \\
5.1275 \\
5.1946 \\
5.2203 \\
5.2237 \\
5.3705 \\
5.4363\end{array}$ & $\begin{array}{l}\text { kcal/mole } \\
28.54 \\
28.886 \\
28.913 \\
28.942 \\
28.943 \\
29.06 \\
29.17\end{array}$ & $\begin{array}{l}k c a l / m o l e \\
28.54 \\
25.735 \\
25.439 \\
25.122 \\
25.099 \\
23.80 \\
22.47\end{array}$ & $\begin{array}{c}-22.4968 \\
-20.3531 \\
-18.4144 \\
-18.2843 \\
-13.003 \\
-9.822\end{array}$ \\
\hline $\begin{array}{r}600 \\
700 \\
800 \\
900 \\
1,000\end{array}$ & $\begin{array}{l}-38.0058 \\
-38.8111 \\
-39.5123 \\
-40.1327 \\
-40.6886\end{array}$ & $\begin{array}{l}\text { 5. } 2074 \\
\text { 5. } 2400 \\
\text { 5. } 2608 \\
\text { 5. } 2729 \\
\text { 5. } 2788\end{array}$ & $\begin{array}{l}\text { 43. } 2132 \\
\text { 44. } 0511 \\
\text { 44. } 7731 \\
\text { 45. } 4056 \\
\text { 45. } 9674\end{array}$ & $\begin{array}{l}3124.4 \\
3668.0 \\
4208.6 \\
4745.6 \\
5278.8\end{array}$ & $\begin{array}{l}\text { 5. } 4448 \\
\text { 5. } 4232 \\
\text { 5. } 3887 \\
\text { 5. } 3506 \\
\text { 5. } 3133\end{array}$ & $\begin{array}{l}29.28 \\
29.39 \\
29.49 \\
29.58 \\
29.66\end{array}$ & $\begin{array}{l}21.12 \\
19.75 \\
18.37 \\
16.97 \\
15.57\end{array}$ & $\begin{array}{l}-7.693 \\
-6.166 \\
-5.018 \\
-4.121 \\
-3.402\end{array}$ \\
\hline $\begin{array}{l}1,100 \\
1,200 \\
1,300 \\
1,400 \\
1,500\end{array}$ & $\begin{array}{l}-41.1918 \\
-41.6512 \\
-42.0736 \\
-42.4644 \\
-42.8278\end{array}$ & $\begin{array}{l}\text { 5. } 2804 \\
\text { 5. } 2789 \\
\text { 5. } 2754 \\
\text { 5. } 2706 \\
\text { 5. } 2649\end{array}$ & $\begin{array}{l}\text { 46. } 4722 \\
\text { 46. } 9301 \\
\text { 47. } 3490 \\
\text { 47. } 7350 \\
48.0927\end{array}$ & $\begin{array}{l}5808.4 \\
6334.7 \\
6858.0 \\
7378.8 \\
7897.4\end{array}$ & $\begin{array}{l}\text { 5. } 2788 \\
\text { 5. } 2477 \\
\text { 5. } 2201 \\
\text { 5. } 1958 \\
\text { 5. } 1745\end{array}$ & $\begin{array}{l}29.74 \\
29.82 \\
29.89 \\
29.96 \\
30.02\end{array}$ & $\begin{array}{r}14.15 \\
12.73 \\
11.31 \\
9.88 \\
8.44\end{array}$ & $\begin{array}{l}-2.812 \\
-2.319 \\
-1.901 \\
-1.542 \\
-1.229\end{array}$ \\
\hline $\begin{array}{l}1,600 \\
1,700 \\
1,800 \\
1,900 \\
2,000\end{array}$ & $\begin{array}{l}-43.1674 \\
-43.4860 \\
-43.7860 \\
-44.0695 \\
-44.3380\end{array}$ & $\begin{array}{l}\text { 5. } 2586 \\
\text { 5. } 2521 \\
\text { 5. } 2454 \\
\text { 5. } 2387 \\
\text { 5. } 2320\end{array}$ & $\begin{array}{l}\text { 48. } 4260 \\
\text { 48. } 7381 \\
\text { 49. } 0314 \\
\text { 49. } 3082 \\
49.5700\end{array}$ & $\begin{array}{r}8413.8 \\
8928.6 \\
9441.7 \\
9953.5 \\
10464.0\end{array}$ & $\begin{array}{l}\text { 5. } 1557 \\
5.1392 \\
5.1246 \\
5.1117 \\
5.1002\end{array}$ & $\begin{array}{l}30.09 \\
30.15 \\
30.21 \\
30.26 \\
30.31\end{array}$ & $\begin{array}{l}7.00 \\
5.55 \\
4.10 \\
2.65 \\
1.20\end{array}$ & $\begin{array}{r}-0.956 \\
-.713 \\
-.498 \\
-.304 \\
-.131\end{array}$ \\
\hline $\begin{array}{l}2,100 \\
2,200 \\
2,300 \\
2,400 \\
2,500\end{array}$ & $\begin{array}{l}-44.5931 \\
-44.8361 \\
-45.0679 \\
-45.2896 \\
-45.5021\end{array}$ & $\begin{array}{l}\text { 5. } 2255 \\
\text { 5. } 2192 \\
\text { 5. } 2130 \\
\text { 5. } 2070 \\
\text { 5. } 2012\end{array}$ & $\begin{array}{l}49.8186 \\
50.0553 \\
50.2809 \\
50.4966 \\
50.7033\end{array}$ & $\begin{array}{l}10973.6 \\
11482.2 \\
11989.9 \\
12496.8 \\
13003.0\end{array}$ & $\begin{array}{l}\text { 5. } 0900 \\
5.0809 \\
5.0727 \\
5.0654 \\
5.0588\end{array}$ & $\begin{array}{l}30.37 \\
30.42 \\
30.46 \\
30.51 \\
30.56\end{array}$ & $\begin{array}{l}-0.26 \\
-1.87 \\
-3.18 \\
-4.65 \\
-6.12\end{array}$ & $\begin{array}{l}.027 \\
.186 \\
.302 \\
.423 \\
.535\end{array}$ \\
\hline $\begin{array}{l}2,750 \\
3,000 \\
3,250 \\
3,500 \\
3,750\end{array}$ & $\begin{array}{l}-45.9972 \\
-46.4480 \\
-46.8618 \\
-47.2441 \\
-47.5994\end{array}$ & $\begin{array}{l}\text { 5. } 1876 \\
5.1752 \\
5.1640 \\
5.1538 \\
5.1445\end{array}$ & $\begin{array}{l}\text { 51. } 1848 \\
51.6232 \\
52.0258 \\
52.3979 \\
52.7439\end{array}$ & $\begin{array}{l}14265.9 \\
15525.6 \\
16783.0 \\
18038.3 \\
19291.9\end{array}$ & $\begin{array}{l}\text { 5. } 0449 \\
5.0339 \\
5.0251 \\
\text { 5. } 0179 \\
5.0120\end{array}$ & \begin{tabular}{l}
30.67 \\
30.76 \\
\\
\hdashline
\end{tabular} & $\begin{array}{r}-9.86 \\
-13.47 \\
-\end{array}$ & $\begin{array}{r}.783 \\
.981 \\
\\
\end{array}$ \\
\hline $\begin{array}{l}4,000 \\
4,250 \\
4,500 \\
4,750 \\
5,000\end{array}$ & $\begin{array}{l}-47.9311 \\
-48.2422 \\
-48.5352 \\
-48.8119 \\
-49.0744\end{array}$ & $\begin{array}{l}\text { 5. } 1361 \\
5.1284 \\
5.1213 \\
\text { 5. } 1148 \\
5.1088\end{array}$ & $\begin{array}{l}\text { 53. } 0672 \\
53.3706 \\
53.6565 \\
53.9267 \\
54.1832\end{array}$ & $\begin{array}{l}20544.4 \\
21795.7 \\
23045.8 \\
24295.3 \\
25544.0\end{array}$ & $\begin{array}{l}\text { 5. } 0070 \\
5.0028 \\
4.9993 \\
4.9964 \\
4.9941\end{array}$ & - & - & - \\
\hline
\end{tabular}

TABLE 11. Thermodynamic properties of $\mathrm{Cl}_{2}$ (g)

\begin{tabular}{|c|c|c|c|c|c|c|c|c|}
\hline$T$ & $\left(F^{\circ}-H_{0}^{\circ}\right) / T$ & $\left(H^{\circ}-H_{0}^{\circ}\right) / T$ & $S^{\circ}$ & $H^{\circ}-H_{0}^{\circ}$ & $C_{p}^{\circ}$ & $\Delta H f^{\circ}$ & $\Delta F f^{\circ}$ & $\log K f$ \\
\hline $\begin{array}{l}{ }^{\circ} \mathbf{K} \\
0 \\
250 \\
273.16 \\
298.16 \\
300 \\
400 \\
500\end{array}$ & $\begin{array}{c}\text { cal/deg mole } \\
0 \\
-44.649 \\
-45.292 \\
-45.934 \\
-45.979 \\
-48.130 \\
-49.847\end{array}$ & $\begin{array}{c}\text { cal/deg mole } \\
0 \\
7.233 \\
7.293 \\
7.357 \\
7.362 \\
7.595 \\
7.783\end{array}$ & $\begin{array}{c}\text { calldeg mole } \\
0 \\
51.882 \\
52.585 \\
53.291 \\
53.341 \\
55.725 \\
57.630\end{array}$ & $\begin{array}{c}\text { callmole } \\
0 \\
1808.2 \\
1992.2 \\
2193.6 \\
2208.6 \\
3038.0 \\
3891.5\end{array}$ & $\begin{array}{c}\text { cal/deg mole } \\
0 \\
7.88 \\
8.00 \\
8.11 \\
8.12 \\
8.44 \\
8.62\end{array}$ & $\begin{array}{c}\text { kcal /mole } \\
0 \\
0 \\
0 \\
0 \\
0 \\
0 \\
0\end{array}$ & $\begin{array}{c}\text { kcal/mole } \\
0 \\
0 \\
0 \\
0 \\
0 \\
0 \\
0\end{array}$ & $\begin{array}{l}0 \\
0 \\
0 \\
0 \\
0 \\
0\end{array}$ \\
\hline $\begin{array}{r}600 \\
700 \\
800 \\
900 \\
1,000\end{array}$ & $\begin{array}{l}-51.278 \\
-52.511 \\
-53.594 \\
-54.560 \\
-55.432\end{array}$ & $\begin{array}{l}\text { 7. } 935 \\
8.057 \\
\text { 8. } 156 \\
\text { 8. } 238 \\
\text { 8. } 309\end{array}$ & $\begin{array}{l}59.213 \\
60.568 \\
61.750 \\
62.798 \\
63.741\end{array}$ & $\begin{array}{l}4761.0 \\
5639.9 \\
6524.8 \\
7414.2 \\
8309.0\end{array}$ & $\begin{array}{l}8.74 \\
8.82 \\
8.88 \\
8.92 \\
8.96\end{array}$ & $\begin{array}{l}0 \\
0 \\
0 \\
0 \\
0\end{array}$ & $\begin{array}{l}0 \\
0 \\
0 \\
0 \\
0\end{array}$ & $\begin{array}{l}0 \\
0 \\
0 \\
0 \\
0\end{array}$ \\
\hline $\begin{array}{l}1,100 \\
1,200 \\
1,300 \\
1,400 \\
1,500\end{array}$ & $\begin{array}{l}-56.226 \\
-56.956 \\
-57.633 \\
-58.263 \\
-58.851\end{array}$ & $\begin{array}{l}\text { 8. } 370 \\
8.423 \\
8.469 \\
8.510 \\
8.548\end{array}$ & $\begin{array}{l}64.596 \\
65.379 \\
66.102 \\
66.773 \\
67.399\end{array}$ & $\begin{array}{r}9207.0 \\
10107.6 \\
11009.7 \\
11914.0 \\
12822.0\end{array}$ & $\begin{array}{l}\text { 8. } 99 \\
9.02 \\
9.04 \\
9.06 \\
9.08\end{array}$ & $\begin{array}{l}0 \\
0 \\
0 \\
0 \\
0\end{array}$ & $\begin{array}{l}0 \\
0 \\
0 \\
0 \\
0\end{array}$ & $\begin{array}{l}0 \\
0 \\
0 \\
0 \\
0\end{array}$ \\
\hline $\begin{array}{l}1,600 \\
1,700 \\
1,800 \\
1,900 \\
2,000\end{array}$ & $\begin{array}{l}-59.404 \\
-59.925 \\
-60.418 \\
-60.885 \\
-61.331\end{array}$ & $\begin{array}{l}\text { 8. } 581 \\
\text { 8. } 611 \\
\text { 8. } 640 \\
8.665 \\
8.690\end{array}$ & $\begin{array}{l}67.985 \\
68.536 \\
69.058 \\
69.550 \\
70.021\end{array}$ & $\begin{array}{l}13729.6 \\
14638.7 \\
15552.0 \\
16463.5 \\
17380.0\end{array}$ & $\begin{array}{l}9.10 \\
9911 \\
9.13 \\
9.14 \\
9.16\end{array}$ & $\begin{array}{l}0 \\
0 \\
0 \\
0 \\
0\end{array}$ & $\begin{array}{l}0 \\
0 \\
0 \\
0 \\
0\end{array}$ & $\begin{array}{l}0 \\
0 \\
0 \\
0 \\
0\end{array}$ \\
\hline $\begin{array}{l}2,100 \\
2,200 \\
2,300 \\
2,400 \\
2,500\end{array}$ & $\begin{array}{l}-61.756 \\
-62.162 \\
-62.550 \\
-62.923 \\
-63.281\end{array}$ & $\begin{array}{l}\text { 8. } 712 \\
\text { 8. } 734 \\
\text { 8. } 754 \\
8.773 \\
8.791\end{array}$ & $\begin{array}{l}70.468 \\
70.896 \\
71.304 \\
71.696 \\
72.072\end{array}$ & $\begin{array}{l}18295.2 \\
19214.8 \\
20134.2 \\
21055.2 \\
21977.5\end{array}$ & $\begin{array}{l}\text { 9. } 17 \\
99.19 \\
9.20 \\
9.22 \\
9.23\end{array}$ & $\begin{array}{l}0 \\
0 \\
0 \\
0 \\
0\end{array}$ & $\begin{array}{l}0 \\
0 \\
0 \\
0 \\
0\end{array}$ & $\begin{array}{l}0 \\
0 \\
0 \\
0 \\
0\end{array}$ \\
\hline $\begin{array}{l}2,750 \\
3,000\end{array}$ & $\begin{array}{l}-64.069 \\
-64.891\end{array}$ & $\begin{array}{l}8.824 \\
8.870\end{array}$ & $\begin{array}{l}72.893 \\
73.761\end{array}$ & $\begin{array}{l}24266.0 \\
26610.0\end{array}$ & $\begin{array}{l}\text { 9. } 26 \\
9.30\end{array}$ & $\begin{array}{l}0 \\
0\end{array}$ & $\begin{array}{l}0 \\
0\end{array}$ & $\begin{array}{l}0 \\
0\end{array}$ \\
\hline
\end{tabular}


TABle 12. Thermodynamic properties of $\mathrm{ClO}_{2}(\mathrm{~g})$

\begin{tabular}{|c|c|c|c|c|c|c|c|c|}
\hline$T$ & $\left(F^{\circ}-H_{0}^{\circ}\right) / T$ & $\left(H^{\circ}-H_{0}^{\circ}\right) / T$ & $S^{\circ}$ & $H^{\circ}-H_{0}^{\circ}$ & $C_{p}^{\circ}$ & $\Delta H f^{\circ}$ & $\Delta F f^{\circ}$ & $\log K f$ \\
\hline $\begin{array}{l}{ }^{\circ} K \\
0 \\
250 \\
273.16 \\
298.16 \\
300 \\
400 \\
500\end{array}$ & $\begin{array}{c}\text { cal/deg mole } \\
0 \\
-49.910 \\
-50.661 \\
-51.413 \\
-51.467 \\
-54.019 \\
-56.101\end{array}$ & $\begin{array}{c}\text { cal/deg mole } \\
0 \\
8.431 \\
8.531 \\
8.642 \\
8.651 \\
9.115 \\
9.561\end{array}$ & $\begin{array}{c}\text { cal/deg mole } \\
0 \\
58.341 \\
59.192 \\
60.055 \\
60.118 \\
63.134 \\
65.662\end{array}$ & $\begin{array}{c}\text { cal/mole } \\
0 \\
2107.8 \\
2330.3 \\
2576.7 \\
2595.3 \\
3646.0 \\
4780.5\end{array}$ & $\begin{array}{c}\text { cal/deg mole } \\
0 \\
9.50 \\
9.74 \\
10.00 \\
10.02 \\
10.96 \\
11.69\end{array}$ & $\begin{array}{l}\text { kcal/mole } \\
25.590 \\
25.061 \\
25.025 \\
25.0 \\
24.998 \\
24.92 \\
24.90\end{array}$ & $\begin{array}{l}\text { kcal/mole } \\
25.590 \\
28.902 \\
29.258 \\
29.6 \\
29.678 \\
31.25 \\
32.84\end{array}$ & $\begin{array}{l}-25.2660 \\
-23.4088 \\
-21.73 \\
-21.6204 \\
-17.076 \\
-14.354\end{array}$ \\
\hline $\begin{array}{r}600 \\
700 \\
800 \\
900 \\
1,000\end{array}$ & $\begin{array}{l}-57.881 \\
-59.444 \\
-60.841 \\
-62.108 \\
-63.268\end{array}$ & $\begin{array}{r}9.963 \\
10.316 \\
10.622 \\
10.888 \\
11.120\end{array}$ & $\begin{array}{l}67.844 \\
69.760 \\
71.463 \\
72.996 \\
74.388\end{array}$ & $\begin{array}{r}5977.8 \\
7221.2 \\
8497.6 \\
9799.2 \\
11120.0\end{array}$ & $\begin{array}{l}12.22 \\
12.61 \\
12.90 \\
13.12 \\
13.29\end{array}$ & $\begin{array}{l}24.91 \\
24.93 \\
24.97 \\
25.01 \\
25.06\end{array}$ & $\begin{array}{l}34.42 \\
36.01 \\
37.59 \\
39.16 \\
40.74\end{array}$ & $\begin{array}{r}-12.539 \\
-11.242 \\
-10.269 \\
-9.510 \\
-8.902\end{array}$ \\
\hline $\begin{array}{l}1,100 \\
1,200 \\
1,300 \\
1,400 \\
1,500\end{array}$ & $\begin{array}{l}-64.338 \\
-65.331 \\
-66.258 \\
-67.127 \\
-67.946\end{array}$ & $\begin{array}{l}11.323 \\
11.502 \\
11.661 \\
11.804 \\
11.932\end{array}$ & $\begin{array}{l}75.661 \\
76.833 \\
77.919 \\
78.931 \\
79.878\end{array}$ & $\begin{array}{l}12455.3 \\
13802.4 \\
15159.3 \\
16525.6 \\
17898.0\end{array}$ & $\begin{array}{l}13.42 \\
13.53 \\
13.61 \\
13.68 \\
13.74\end{array}$ & $\begin{array}{l}25.11 \\
25.16 \\
25.20 \\
25.25 \\
25.30\end{array}$ & $\begin{array}{l}42.30 \\
43.86 \\
45.42 \\
46.97 \\
48.52\end{array}$ & $\begin{array}{l}-8.404 \\
-7.988 \\
-7.635 \\
-7.332 \\
-7.070\end{array}$ \\
\hline
\end{tabular}

TABLE 13. Thermodynamic properties of $\mathrm{Cl}_{2} \mathrm{O}(\mathrm{g})$

\begin{tabular}{|c|c|c|c|c|c|c|c|c|}
\hline$T$ & $\left(F^{\circ}-H_{0}^{\circ}\right) / T$ & $\left(H^{\circ}-H_{0}^{\circ}\right) / T$ & $S^{\circ}$ & $H^{\circ}-H_{0}^{\circ}$ & $C_{p}^{\circ}$ & $\Delta H f^{\circ}$ & $\Delta F f^{\circ}$ & $\log K f$ \\
\hline $\begin{array}{l}{ }^{\circ} K \\
0 \\
250 \\
273.16 \\
298.16 \\
300 \\
400 \\
500\end{array}$ & $\begin{array}{c}\text { cal/deg mole } \\
0 \\
-52.94 \\
-53.73 \\
-54.52 \\
-54.59 \\
-57.29 \\
-59.49\end{array}$ & $\begin{array}{c}\text { cal/deg mole } \\
0 \\
8.84 \\
8.97 \\
9.12 \\
9.13 \\
9.68 \\
10.16\end{array}$ & $\begin{array}{c}\text { cal/deg mole } \\
0 \\
61.78 \\
62.70 \\
63.64 \\
63.72 \\
66.96 \\
69.65\end{array}$ & $\begin{array}{c}\text { cal/mole } \\
0 \\
2210 \\
2450 \\
2719 \\
2739 \\
3872 \\
5080\end{array}$ & $\begin{array}{c}\text { cal/deg mole } \\
0 \\
10.3 \\
10.6 \\
10.9 \\
10.9 \\
11.7 \\
12.3\end{array}$ & $\begin{array}{c}\text { kcal/mole } \\
18.61 \\
18.15 \\
18.12 \\
18.1 \\
18.10 \\
18.05 \\
18.04\end{array}$ & $\begin{array}{c}\text { kcal/mole } \\
18.61 \\
21.64 \\
21.97 \\
22.3 \\
22.34 \\
23.77 \\
25.21\end{array}$ & $\begin{array}{l}-18.919 \\
-17.574 \\
-16.36 \\
-16.276 \\
-12.989 \\
-11.018\end{array}$ \\
\hline $\begin{array}{r}600 \\
700 \\
800 \\
900 \\
1,000\end{array}$ & $\begin{array}{l}-61.38 \\
-63.03 \\
-64.50 \\
-65.83 \\
-67.04\end{array}$ & $\begin{array}{r}10.55 \\
0.88 \\
11.16 \\
11.39 \\
11.59\end{array}$ & $\begin{array}{l}71.93 \\
73.91 \\
75.66 \\
77.22 \\
78.63\end{array}$ & $\begin{array}{r}6330 \\
7616 \\
8928 \\
10251 \\
11590\end{array}$ & $\begin{array}{l}\text { 12. } 7 \\
13.0 \\
13.2 \\
13.3 \\
13.4\end{array}$ & $\begin{array}{l}\text { 18. } 04 \\
18.06 \\
18.09 \\
18.11 \\
18.14\end{array}$ & $\begin{array}{l}26.64 \\
28.07 \\
29.50 \\
30.93 \\
32.35\end{array}$ & $\begin{array}{l}-9.704 \\
-8.764 \\
-8.060 \\
-7.510 \\
-7.070\end{array}$ \\
\hline $\begin{array}{l}1,100 \\
1,200 \\
1,300 \\
1,400 \\
1,500\end{array}$ & $\begin{array}{l}-68.16 \\
-69.19 \\
-70.14 \\
-71.04 \\
-71.91\end{array}$ & $\begin{array}{l}11.76 \\
11.91 \\
12.04 \\
12.16 \\
12.27\end{array}$ & $\begin{array}{l}79.92 \\
81.10 \\
82.18 \\
83.20 \\
84.18\end{array}$ & $\begin{array}{l}12936 \\
14292 \\
15652 \\
17024 \\
18405\end{array}$ & $\begin{array}{l}13.5 \\
13.6 \\
13.6 \\
13.7 \\
13.7\end{array}$ & $\begin{array}{l}\text { 18. } 17 \\
18.20 \\
\text { 18. } 23 \\
\text { 18. } 27 \\
18.31\end{array}$ & $\begin{array}{l}33.76 \\
35.18 \\
36.60 \\
38.01 \\
39.39\end{array}$ & $\begin{array}{l}-6.707 \\
-6.406 \\
-6.153 \\
-5.934 \\
-5.737\end{array}$ \\
\hline
\end{tabular}

TABLE 14. Thermodynamic properties of ClF (g)

\begin{tabular}{|c|c|c|c|c|c|c|c|c|}
\hline$T$ & $\left(F^{\circ}-H_{0}^{\circ}\right) / T$ & $\left(H^{\circ}-H_{\mathrm{c}}^{\circ}\right) / T$ & $S^{\circ}$ & $H^{\circ}-H_{0}^{\circ}$ & $C_{p}^{\circ}$ & $\Delta H f^{\circ}$ & $\Delta F f^{\circ}$ & $\log K f$ \\
\hline $\begin{array}{l}{ }^{\circ} K \\
0 \\
250 \\
273.16 \\
298.16 \\
300 \\
400 \\
500\end{array}$ & $\begin{array}{c}\text { cal/deg mole } \\
0 \\
-43.672 \\
-44.300 \\
-44.922 \\
-44.966 \\
-47.047 \\
-48.702\end{array}$ & $\begin{array}{c}\text { cal/deg mole } \\
0 \\
7.060 \\
7.098 \\
7.140 \\
7.144 \\
7.329 \\
7.506\end{array}$ & $\begin{array}{c}\text { cal/deg mole } \\
0 \\
50.732 \\
51.398 \\
52.062 \\
52.110 \\
54.376 \\
56.208\end{array}$ & $\begin{array}{c}\text { cal/mole } \\
0 \\
1,765.0 \\
1,938.9 \\
2,128.9 \\
2,143.2 \\
2,931.6 \\
3,753.0\end{array}$ & $\begin{array}{c}\text { calldeg mole } \\
0 \\
7.44 \\
7.55 \\
7.67 \\
7.68 \\
8.07 \\
8.33\end{array}$ & $\begin{array}{l}\text { kcal/mole } \\
-13.4 \\
-13.416 \\
-13.418 \\
-13.423 \\
-13.423 \\
-13.43 \\
-13.44\end{array}$ & $\begin{array}{l}\text { kcal/mole } \\
-13.4 \\
-13.721 \\
-13.749 \\
-13.779 \\
-13.781 \\
-13.90 \\
-14.01\end{array}$ & $\begin{array}{c}11.9945 \\
11.0000 \\
10.0995 \\
10.0391 \\
7.594 \\
6.126\end{array}$ \\
\hline $\begin{array}{r}600 \\
700 \\
800 \\
900 \\
1,000\end{array}$ & $\begin{array}{l}-50.085 \\
-51.275 \\
-52.323 \\
-53.260 \\
-54.107\end{array}$ & $\begin{array}{l}\text { 7. } 659 \\
7.790 \\
7.902 \\
7.997 \\
8.080\end{array}$ & $\begin{array}{l}57.744 \\
59.065 \\
60.225 \\
61.257 \\
62.187\end{array}$ & $\begin{array}{l}4,595.4 \\
5,453.0 \\
6,321.6 \\
7,197.3 \\
8,080.0\end{array}$ & $\begin{array}{l}8.51 \\
8.64 \\
8.73 \\
8.80 \\
8.85\end{array}$ & $\begin{array}{l}-13.45 \\
-13.46 \\
-13.46 \\
-13.47 \\
-13.47\end{array}$ & $\begin{array}{l}-14.13 \\
-14.24 \\
-14.35 \\
-14.46 \\
-14.57\end{array}$ & $\begin{array}{l}5.146 \\
4.446 \\
3.921 \\
3.512 \\
3.185\end{array}$ \\
\hline $\begin{array}{l}1,100 \\
1,200 \\
1,300 \\
1,400 \\
1,500\end{array}$ & $\begin{array}{l}-54.880 \\
-55.592 \\
-56.252 \\
-56.867 \\
-57.442\end{array}$ & $\begin{array}{l}8.153 \\
8.216 \\
8.271 \\
8.320 \\
8.366\end{array}$ & $\begin{array}{l}63.033 \\
63.808 \\
64.523 \\
65.187 \\
65.808\end{array}$ & $\begin{array}{r}8,968.3 \\
9,859.2 \\
10,752.3 \\
11,648.0 \\
12,549.0\end{array}$ & $\begin{array}{l}8.89 \\
8.93 \\
8.96 \\
8.98 \\
9.00\end{array}$ & $\begin{array}{l}-13.48 \\
-13.48 \\
-13.49 \\
-13.49 \\
-13.50\end{array}$ & $\begin{array}{l}-14.68 \\
-14.79 \\
-14.90 \\
-15.01 \\
-15.12\end{array}$ & $\begin{array}{l}2.917 \\
2.694 \\
2.505 \\
2.343 \\
2.203\end{array}$ \\
\hline
\end{tabular}


TABLE 15. Thermodynamic properties of $\mathrm{ClF}_{3}(\mathrm{~g})$

\begin{tabular}{|c|c|c|c|c|c|c|c|c|}
\hline$T$ & $\left(F^{\circ}-H_{\rho}^{\circ}\right) / T$ & $\left(H^{\circ}-H_{0}^{\circ}\right) / T$ & $S^{\circ}$ & $H^{\circ}-H_{0}^{\circ}$ & $C_{p}^{\circ}$ & $\Delta H f^{\circ}$ & $\Delta F f^{\circ}$ & $\log K f$ \\
\hline $\begin{array}{l}{ }^{\circ} K \\
\quad 0 \\
250 \\
273.16 \\
298.16 \\
300 \\
400 \\
500\end{array}$ & $\begin{array}{c}\text { cal/deg mole } \\
0 \\
-54.81 \\
-55.76 \\
-56.73 \\
-56.80 \\
-60.24 \\
-63.16\end{array}$ & $\begin{array}{c}\text { cal/deg mole } \\
0 \\
10.59 \\
10.94 \\
11.31 \\
11.33 \\
12.59 \\
13.58\end{array}$ & $\begin{array}{c}\text { cal/deg mole } \\
0 \\
65.40 \\
66.70 \\
68.04 \\
68.13 \\
72.83 \\
76.74\end{array}$ & $\begin{array}{l}\text { cal/mole } \\
0 \\
2,647.5 \\
2,988.4 \\
3,372.2 \\
3,399.0 \\
5,036 \\
6,790\end{array}$ & $\begin{array}{c}\text { calideg mole } \\
0 \\
14.48 \\
15.03 \\
15.55 \\
15.58 \\
17.05 \\
17.92\end{array}$ & $\begin{array}{c}k c a l / \text { mole } \\
-37.9 \\
-38.79 \\
-38.79 \\
-38.79 \\
-38.79 \\
-38.72 \\
-38.60\end{array}$ & $\begin{array}{c}\text { kcal/mole } \\
-37.9 \\
-30.97 \\
-30.24 \\
-29.46 \\
-29.41 \\
-26.29 \\
-23.19\end{array}$ & $\begin{array}{l}27.076 \\
24.193 \\
21.597 \\
21.422 \\
14.363 \\
10.138\end{array}$ \\
\hline $\begin{array}{r}600 \\
700 \\
800 \\
900 \\
1,000\end{array}$ & $\begin{array}{l}-65.71 \\
-67.97 \\
-70.00 \\
-71.84 \\
-73.52\end{array}$ & $\begin{array}{l}14.35 \\
14.96 \\
15.45 \\
15.86 \\
16.20\end{array}$ & $\begin{array}{l}80.06 \\
82.93 \\
85.45 \\
87.70 \\
89.72\end{array}$ & $\begin{array}{r}8,610 \\
10,472 \\
12,360 \\
14,274 \\
16,200\end{array}$ & $\begin{array}{l}18.45 \\
18.80 \\
19.03 \\
19.20 \\
19.32\end{array}$ & $\begin{array}{l}-38.46 \\
-38.31 \\
-38.16 \\
-38.00 \\
-37.84\end{array}$ & $\begin{array}{r}-20.13 \\
-17.09 \\
-14.06 \\
-11.05 \\
-8.05\end{array}$ & $\begin{array}{l}\text { 7. } 340 \\
5.332 \\
3.840 \\
\text { 2. } 682 \\
\text { 1. } 176\end{array}$ \\
\hline $\begin{array}{l}1,100 \\
1,200 \\
1,300 \\
1,400 \\
1,500\end{array}$ & $\begin{array}{l}-75.08 \\
-76.54 \\
-77.90 \\
-79.16 \\
-80.34\end{array}$ & $\begin{array}{l}16.49 \\
16.74 \\
16.95 \\
17.13 \\
17.30\end{array}$ & $\begin{array}{l}91.57 \\
93.28 \\
94.85 \\
96.29 \\
97.64\end{array}$ & $\begin{array}{l}18,139 \\
29,088 \\
22,035 \\
23,982 \\
25,950\end{array}$ & $\begin{array}{l}19.41 \\
19.48 \\
19.54 \\
19.59 \\
19.63\end{array}$ & $\begin{array}{l}-37.69 \\
-37.53 \\
-37.37 \\
-37.22 \\
-37.07\end{array}$ & $\begin{array}{r}-5.08 \\
-2.14 \\
0.78 \\
3.71 \\
6.65\end{array}$ & $\begin{array}{r}1.010 \\
0.391 \\
-.132 \\
-.581 \\
-.969\end{array}$ \\
\hline
\end{tabular}

TABLE 16. Thermodynamic properties of $\mathrm{Br}(\mathrm{g})$

\begin{tabular}{|c|c|c|c|c|c|c|c|c|}
\hline$T$ & $\left(F^{\circ}-H_{0}^{\circ}\right) / T$ & $\left(H^{\circ}-H_{0}^{\circ}\right) / T$ & $S^{\circ}$ & $H^{\circ}-H_{0}^{\circ}$ & $C_{p}^{\circ}$ & $\Delta I I f^{\circ}$ & $\Delta F f^{\circ}$ & $\log K f$ \\
\hline $\begin{array}{l}{ }^{\circ} K \\
\quad 0 \\
250 \\
273.16 \\
298.16 \\
300 \\
400 \\
500\end{array}$ & $\begin{array}{c}\text { cal/deg mole } \\
0 \\
-35.9620 \\
-36.4022 \\
-36.8372 \\
-36.8678 \\
-38.2970 \\
-39.4057\end{array}$ & $\begin{array}{c}\text { cal/deg mole } \\
0 \\
4.9680 \\
4.9680 \\
4.9680 \\
4.9680 \\
4.9680 \\
4.9682\end{array}$ & $\begin{array}{c}\text { cal/deg mole } \\
0 \\
40.9300 \\
41.3702 \\
41.8052 \\
41.8358 \\
43.2650 \\
44.3739\end{array}$ & $\begin{array}{c}\text { cal/mole } \\
0 \\
1,242.0 \\
1,357.1 \\
1,481.3 \\
1,490.4 \\
1,987.2 \\
2,484.1\end{array}$ & $\begin{array}{c}\text { cal/deg mole } \\
0 \\
4.9680 \\
4.9680 \\
4.9680 \\
4.9680 \\
4.9683 \\
4.9708\end{array}$ & $\begin{array}{l}k c a l / \text { mole } \\
22.73 \\
23.016 \\
23.032 \\
23.049 \\
23.050 \\
23.11 \\
23.17\end{array}$ & $\begin{array}{c}k c a l / \text { mole } \\
22.73 \\
19.926 \\
19.639 \\
19.327 \\
19.305 \\
18.05 \\
16.77\end{array}$ & $\begin{array}{c}-17.4189 \\
-15.7125 \\
-14.166 \\
-14.0633 \\
-9.860 \\
-7.332\end{array}$ \\
\hline $\begin{array}{r}600 \\
700 \\
800 \\
900 \\
1,000\end{array}$ & $\begin{array}{l}-40.3115 \\
-41.0776 \\
-41.7418 \\
-42.3285 \\
-42.8541\end{array}$ & $\begin{array}{l}\text { 4. } 9693 \\
\text { 4. } 9718 \\
\text { 4. } 9767 \\
\text { 4. } 9841 \\
\text { 4. } 9942\end{array}$ & $\begin{array}{l}45.2808 \\
46.0494 \\
46.7185 \\
47.3125 \\
47.8483\end{array}$ & $\begin{array}{l}2,981.6 \\
3,480.3 \\
3,981.4 \\
4,485.7 \\
4,994.2\end{array}$ & $\begin{array}{l}\text { 4. } 9793 \\
\text { 4. } 9973 \\
5.0257 \\
5.0631 \\
5.1065\end{array}$ & $\begin{array}{l}23.22 \\
23.27 \\
23.33 \\
23.38 \\
23.44\end{array}$ & $\begin{array}{l}15.49 \\
14.20 \\
12.90 \\
11.59 \\
10.28\end{array}$ & $\begin{array}{l}-5.642 \\
-4.432 \\
-3.523 \\
-2.814 \\
-2.246\end{array}$ \\
\hline $\begin{array}{l}1,100 \\
1,200 \\
1,300 \\
1,400 \\
1,500\end{array}$ & $\begin{array}{l}-43.3306 \\
-43.7669 \\
-44.1693 \\
-44.5431 \\
-44.8922\end{array}$ & $\begin{array}{l}\text { 5. } 0065 \\
\text { 5. } 0206 \\
\text { 5. } 0361 \\
\text { 5. } 0523 \\
\text { 5. } 0690\end{array}$ & $\begin{array}{l}48.3371 \\
48.7875 \\
49.2054 \\
49.5954 \\
49.9612\end{array}$ & $\begin{array}{l}5,507.2 \\
6,024.7 \\
6,546.9 \\
7,073.2 \\
7,603.5\end{array}$ & $\begin{array}{l}\text { 5. } 1528 \\
5.1991 \\
5.2433 \\
5.2838 \\
5.3198\end{array}$ & $\begin{array}{l}23.50 \\
23.57 \\
23.64 \\
23.71 \\
23.79\end{array}$ & $\begin{array}{l}8.96 \\
7.63 \\
6.30 \\
4.97 \\
3.62\end{array}$ & $\begin{array}{r}-1.780 \\
-1.390 \\
-1.060 \\
-0.975 \\
-.528\end{array}$ \\
\hline $\begin{array}{l}1,600 \\
1,700 \\
1,800 \\
1,900 \\
2,000\end{array}$ & $\begin{array}{l}-45.2290 \\
-45.5288 \\
-45.8238 \\
-46.0979 \\
-46.3616\end{array}$ & $\begin{array}{l}\text { 5. } 0857 \\
5.1021 \\
5.1180 \\
5.1332 \\
5.1476\end{array}$ & $\begin{array}{l}50.3057 \\
50.6309 \\
50.9388 \\
51.2311 \\
51.5092\end{array}$ & $\begin{array}{r}8,137.1 \\
8,673.6 \\
9,212.4 \\
9,753.1 \\
10,295.2\end{array}$ & $\begin{array}{l}\text { 5. } 3509 \\
\text { 5. } 3770 \\
5.3883 \\
\text { 5. } 4151 \\
\text { 5. } 4279\end{array}$ & $\begin{array}{l}23.87 \\
23.95 \\
24.03 \\
24.12 \\
24.20\end{array}$ & $\begin{array}{r}2.28 \\
0.92 \\
-.43 \\
-1.79 \\
-3.16\end{array}$ & $\begin{array}{r}-.311 \\
-.119 \\
.052 \\
.206 \\
.345\end{array}$ \\
\hline $\begin{array}{l}2,100 \\
2,200 \\
2,300 \\
2,400 \\
2,500\end{array}$ & $\begin{array}{l}-46.6131 \\
-46.8535 \\
-47.0838 \\
-47.3047 \\
-47.5170\end{array}$ & $\begin{array}{l}\text { 5. } 1612 \\
5.1739 \\
5.1856 \\
5.1965 \\
\text { 5. } 2065\end{array}$ & $\begin{array}{l}51.7743 \\
52.0274 \\
52.2694 \\
52.5012 \\
52.7235\end{array}$ & $\begin{array}{l}10,838.5 \\
11,382.6 \\
11,920.9 \\
12,471.6 \\
13,016.3\end{array}$ & $\begin{array}{l}\text { 5. } 4369 \\
5.4427 \\
5.4457 \\
5.4464 \\
5.4451\end{array}$ & $\begin{array}{l}24.29 \\
24.37 \\
24.46 \\
24.54 \\
24.63\end{array}$ & $\begin{array}{r}-4.53 \\
-5.90 \\
-7.28 \\
-8.66 \\
-10.05\end{array}$ & $\begin{array}{l}.471 \\
.586 \\
.692 \\
.789 \\
.878\end{array}$ \\
\hline $\begin{array}{l}2,750 \\
3,000 \\
3,250 \\
3,500 \\
3,750\end{array}$ & $\begin{array}{l}-48.0143 \\
-48.4599 \\
-48.8902 \\
-49.2801 \\
-49.6437\end{array}$ & $\begin{array}{l}\text { 5. } 2277 \\
\text { 5. } 2443 \\
\text { 5. } 2569 \\
\text { 5. } 2361 \\
\text { 5. } 2726\end{array}$ & $\begin{array}{l}53.2420 \\
53.7142 \\
54.1471 \\
54.5462 \\
54.9163\end{array}$ & $\begin{array}{l}14,376.2 \\
15,732.9 \\
17,084.9 \\
18,431.4 \\
19,772.3\end{array}$ & $\begin{array}{l}\text { 5. } 4348 \\
5.4178 \\
5.3972 \\
5.3748 \\
5.3519\end{array}$ & \begin{tabular}{l}
24.84 \\
25.04 \\
\hdashline-0 \\
\end{tabular} & $\begin{array}{l}-13.52 \\
-17.02 \\
\end{array}$ & $\begin{array}{c}1.075 \\
1.240 \\
\end{array}$ \\
\hline $\begin{array}{l}4,000 \\
4,250 \\
4,500 \\
4,750 \\
5,000\end{array}$ & $\begin{array}{l}-49.9841 \\
-50.3041 \\
-50.6059 \\
-50.8914 \\
-51.1622\end{array}$ & $\begin{array}{l}\text { 5. } 2769 \\
\text { 5. } 2793 \\
\text { 5. } 2803 \\
\text { 5. } 2801 \\
\text { 5. } 2790\end{array}$ & $\begin{array}{l}55.2610 \\
55.5834 \\
55.8862 \\
56.1715 \\
56.4412\end{array}$ & $\begin{array}{l}21,107.6 \\
22,437.0 \\
23,761.4 \\
25,080.5 \\
26,395.0\end{array}$ & $\begin{array}{l}\text { 5. } 3293 \\
\text { 5. } 3075 \\
\text { 5. } 2858 \\
\text { 5. } 2673 \\
\text { 5. } 2490\end{array}$ & - & - & - \\
\hline
\end{tabular}


TABLE 17. Thermodynamic properties of $\mathrm{Br}_{2}(\mathrm{~g})$

\begin{tabular}{|c|c|c|c|c|c|c|c|c|}
\hline$T$ & $\left(F^{\circ}-H_{0}^{\circ}\right) / T$ & $\left(H^{\circ}-H_{0}^{\circ}\right) / T$ & $S^{\circ}$ & $H^{\circ}-H_{0}^{\circ}$ & $C_{p}^{\circ}$ & $\Delta H f^{\circ}$ & $\Delta F f^{\circ}$ & $\log K f$ \\
\hline $\begin{array}{l}{ }^{\circ} K \\
0 \\
250 \\
273.16 \\
298.16 \\
300 \\
400 \\
500\end{array}$ & $\begin{array}{c}\text { cal/deg mole } \\
0 \\
-49.491 \\
-50.172 \\
-50.851 \\
-50.899 \\
-53.176 \\
-54.986\end{array}$ & $\begin{array}{c}\text { cal/deg mole } \\
0 \\
7.650 \\
7.724 \\
7.796 \\
7.801 \\
8.028 \\
8.186\end{array}$ & $\begin{array}{c}\text { cal/deg mole } \\
0 \\
57.141 \\
57.896 \\
58.647 \\
58.700 \\
61.204 \\
63.172\end{array}$ & $\begin{array}{c}c a l / m o l e \\
0 \\
1,912.5 \\
2,109.9 \\
2,324.5 \\
2,340.3 \\
3,211.2 \\
4,093.0\end{array}$ & $\begin{array}{c}\text { cal/deg mole } \\
0 \\
8.48 \\
8.55 \\
8.62 \\
8.62 \\
8.78 \\
8.86\end{array}$ & $\begin{array}{c}\text { kcal/mole } \\
0 \\
0 \\
0 \\
0 \\
0 \\
0 \\
0\end{array}$ & $\begin{array}{c}\text { kcal/mole } \\
0 \\
0 \\
0 \\
0 \\
0 \\
0 \\
0\end{array}$ & $\begin{array}{l}0 \\
0 \\
0 \\
0 \\
0 \\
0\end{array}$ \\
\hline $\begin{array}{r}600 \\
700 \\
800 \\
900 \\
1,000\end{array}$ & $\begin{array}{l}-56.489 \\
-57.776 \\
-58.901 \\
-59.901 \\
-60.801\end{array}$ & $\begin{array}{l}8.303 \\
8.392 \\
8.462 \\
8.520 \\
8.568\end{array}$ & $\begin{array}{l}64.792 \\
66.168 \\
67.363 \\
68.421 \\
69.369\end{array}$ & $\begin{array}{l}4,981.8 \\
5,874.4 \\
6,769.6 \\
7,668.0 \\
8,568.0\end{array}$ & $\begin{array}{l}8.91 \\
8.94 \\
8.97 \\
8.99 \\
9.01\end{array}$ & $\begin{array}{l}0 \\
0 \\
0 \\
0 \\
0\end{array}$ & $\begin{array}{l}0 \\
0 \\
0 \\
0 \\
0\end{array}$ & $\begin{array}{l}0 \\
0 \\
0 \\
0 \\
0\end{array}$ \\
\hline $\begin{array}{l}1,100 \\
1,200 \\
1,300 \\
1,400 \\
1,500\end{array}$ & $\begin{array}{l}-61.620 \\
-62.371 \\
-63.064 \\
-63.708 \\
-64.309\end{array}$ & $\begin{array}{l}8.609 \\
8.644 \\
8.676 \\
8.703 \\
8.728\end{array}$ & $\begin{array}{l}70.229 \\
71.015 \\
71.740 \\
72.411 \\
73.037\end{array}$ & $\begin{array}{r}9,469.9 \\
10,372.8 \\
11,278.8 \\
12,184.2 \\
13,092.0\end{array}$ & $\begin{array}{l}9.03 \\
9.04 \\
9.06 \\
9.07 \\
9.08\end{array}$ & $\begin{array}{l}0 \\
0 \\
0 \\
0 \\
0\end{array}$ & $\begin{array}{l}0 \\
0 \\
0 \\
0 \\
0\end{array}$ & $\begin{array}{l}0 \\
0 \\
0 \\
0 \\
0\end{array}$ \\
\hline $\begin{array}{l}1,600 \\
1,700 \\
1,800 \\
1,900 \\
2,000\end{array}$ & $\begin{array}{l}-64.873 \\
-65.404 \\
-65.906 \\
-66.382 \\
-66.834\end{array}$ & $\begin{array}{l}8.750 \\
8.770 \\
8.790 \\
8.807 \\
8.824\end{array}$ & $\begin{array}{l}73.623 \\
74.174 \\
74.696 \\
75.189 \\
75.658\end{array}$ & $\begin{array}{l}14,000.0 \\
14,909.0 \\
15,822.0 \\
16,733.3 \\
17,648.0\end{array}$ & $\begin{array}{l}9.09 \\
9.11 \\
9.12 \\
9.13 \\
9.14\end{array}$ & $\begin{array}{l}0 \\
0 \\
0 \\
0 \\
0\end{array}$ & $\begin{array}{l}0 \\
0 \\
0 \\
0 \\
0\end{array}$ & $\begin{array}{l}0 \\
0 \\
0 \\
0 \\
0\end{array}$ \\
\hline $\begin{array}{l}2,100 \\
2,200 \\
2,300 \\
2,400 \\
2,500\end{array}$ & $\begin{array}{l}-67.265 \\
-67.677 \\
-68.071 \\
-68.448 \\
-68.811\end{array}$ & $\begin{array}{l}8.839 \\
8.853 \\
8.867 \\
8.880 \\
8.892\end{array}$ & $\begin{array}{l}76.104 \\
76.530 \\
76.938 \\
77.328 \\
77.703\end{array}$ & $\begin{array}{l}18,561.9 \\
19,476.6 \\
20,394.1 \\
21,312.0 \\
22,230.0\end{array}$ & $\begin{array}{l}9.15 \\
9.16 \\
9.17 \\
9.18 \\
9.20\end{array}$ & $\begin{array}{l}0 \\
0 \\
0 \\
0 \\
0\end{array}$ & $\begin{array}{l}0 \\
0 \\
0 \\
0 \\
0\end{array}$ & $\begin{array}{l}0 \\
0 \\
0 \\
0 \\
0\end{array}$ \\
\hline $\begin{array}{l}2,750 \\
3,000\end{array}$ & $\begin{array}{l}-69.662 \\
-70.436\end{array}$ & $\begin{array}{l}8.921 \\
8.947\end{array}$ & $\begin{array}{l}78.583 \\
79.383\end{array}$ & $\begin{array}{l}24,532.8 \\
26,841.0\end{array}$ & $\begin{array}{l}9.22 \\
9.25\end{array}$ & $\begin{array}{l}0 \\
0\end{array}$ & $\begin{array}{l}0 \\
0\end{array}$ & $\begin{array}{l}0 \\
0\end{array}$ \\
\hline
\end{tabular}

TABLE 18. Thermodynamic properties of $\mathrm{BrF}$ (g)

\begin{tabular}{|c|c|c|c|c|c|c|c|c|}
\hline$T$ & $\left(F^{\circ}-H_{0}^{\circ}\right) / T$ & $\left(H^{\circ}-H_{0}^{\circ}\right) / T$ & $S^{\circ}$ & $H^{\circ}-H_{0}^{\circ}$ & $C_{p}^{\circ}$ & $\Delta H f^{\circ}$ & $\Delta F f^{\circ}$ & $\log K f$ \\
\hline $\begin{array}{l}{ }^{\circ} K \\
0 \\
250 \\
273.16 \\
298.16 \\
300 \\
400 \\
500\end{array}$ & $\begin{array}{c}\text { cal/deg mole } \\
0 \\
-46.206 \\
-46.839 \\
-47.470 \\
-47.514 \\
-49.625 \\
-51.307\end{array}$ & $\begin{array}{c}\text { cal/deg mole } \\
0 \\
7.128 \\
7.176 \\
7.230 \\
7.234 \\
7.446 \\
7.633\end{array}$ & $\begin{array}{c}\text { cal/deg mole } \\
0 \\
53.334 \\
54.015 \\
54.700 \\
54.748 \\
57.071 \\
58.940\end{array}$ & $\begin{array}{c}\text { cal/mole } \\
0 \\
1,782.0 \\
1,960.2 \\
2,155.7 \\
2,170.2 \\
2,978.4 \\
3,816.5\end{array}$ & $\begin{array}{c}\text { cal/deg mole } \\
0 \\
7.63 \\
7.76 \\
7.88 \\
7.88 \\
8.25 \\
8.49\end{array}$ & $\begin{array}{l}\text { kcal/mole } \\
-18.3 \\
-18.353 \\
-18.355 \\
-18.361 \\
-18.362 \\
-18.37 \\
-18.38\end{array}$ & $\begin{array}{l}\text { kcal/mole } \\
-18.3 \\
-18.649 \\
-18.676 \\
-18.705 \\
-18.707 \\
-18.82 \\
-18.93\end{array}$ & $\begin{array}{c}16.3028 \\
14.9419 \\
13.7107 \\
13.6279 \\
10.283 \\
8.275\end{array}$ \\
\hline $\begin{array}{r}600 \\
700 \\
800 \\
900 \\
1,000\end{array}$ & $\begin{array}{r}-52.713 \\
-53.924 \\
-54.989 \\
-55.940 \\
-56.790\end{array}$ & $\begin{array}{l}7.789 \\
7.918 \\
8.027 \\
8.118 \\
8.196\end{array}$ & $\begin{array}{l}60.502 \\
61.842 \\
63.016 \\
64.058 \\
64.995\end{array}$ & $\begin{array}{l}4,673.4 \\
5,542.6 \\
6,421.6 \\
7,306.2 \\
8,196.0\end{array}$ & $\begin{array}{l}8.64 \\
8.74 \\
8.82 \\
8.88 \\
8.92\end{array}$ & $\begin{array}{l}-18.38 \\
-18.38 \\
-18.38 \\
-18.38 \\
-18.38\end{array}$ & $\begin{array}{l}-19.04 \\
-19.15 \\
-19.26 \\
-19.37 \\
-19.48\end{array}$ & $\begin{array}{l}\text { 6. } 936 \\
\text { 5. } 980 \\
\text { 5. } 262 \\
\text { 4. } 704 \\
\text { 4. } 258\end{array}$ \\
\hline $\begin{array}{l}1,100 \\
1,200 \\
1,300 \\
1,400 \\
1,500\end{array}$ & $\begin{array}{l}-57.584 \\
-58.305 \\
-58.974 \\
-59.596 \\
-60.178\end{array}$ & $\begin{array}{l}8.264 \\
8.323 \\
8.376 \\
8.423 \\
8.465\end{array}$ & $\begin{array}{l}65.848 \\
66.628 \\
67.350 \\
68.019 \\
68.643\end{array}$ & $\begin{array}{r}9,090.4 \\
9,987.6 \\
10,888.8 \\
11,792.2 \\
12,697.5\end{array}$ & $\begin{array}{l}8.96 \\
8.99 \\
9.02 \\
9.04 \\
9.07\end{array}$ & $\begin{array}{l}-18.39 \\
-18.39 \\
-18.39 \\
-18.39 \\
-18.39\end{array}$ & $\begin{array}{l}-19.59 \\
-19.70 \\
-19.81 \\
-19.92 \\
-20.03\end{array}$ & $\begin{array}{l}\text { 3. } 892 \\
\text { 3. } 588 \\
\text { 3. } 330 \\
\text { 3. } 109 \\
\text { 2. } 918\end{array}$ \\
\hline
\end{tabular}

TABLE 19. Thermodynamic properties of $\mathrm{BrF}_{5}(\mathrm{~g})$

\begin{tabular}{|c|c|c|c|c|c|c|c|c|}
\hline$T$ & $\left(F^{\circ}-H_{0}^{0}\right) / T$ & $\left(H^{\circ}-H_{0}^{\circ}\right) / T$ & $S^{\circ}$ & $H^{\circ}-H_{0}^{\circ}$ & $C_{p}^{\circ}$ & $\Delta H f^{\circ}$ & $\Delta F f^{\circ}$ & $\log K f$ \\
\hline $\begin{array}{l}{ }^{\circ} K \\
0 \\
250 \\
273.16 \\
298.16 \\
300 \\
400 \\
500\end{array}$ & $\begin{array}{c}\text { cal/deg mole } \\
0 \\
-58.93 \\
-60.15 \\
-61.43 \\
-61.53 \\
-66.23 \\
-70.41\end{array}$ & $\begin{array}{c}\text { cal/deg mole } \\
0 \\
13.48 \\
14.24 \\
15.01 \\
15.06 \\
17.68 \\
19.68\end{array}$ & $\begin{array}{c}\text { cal/deg mole } \\
0 \\
72.41 \\
74.39 \\
76.44 \\
76.59 \\
83.91 \\
90.09\end{array}$ & $\begin{array}{r}\text { cal/mole } \\
0 \\
3,370 \\
3,890 \\
4,475 \\
4,518 \\
7,072 \\
9,840\end{array}$ & $\begin{array}{c}\text { cal/deg mole } \\
0 \\
21.78 \\
22.90 \\
23.93 \\
24.00 \\
26.82 \\
28.41\end{array}$ & $\begin{array}{c}\text { kcal/mole } \\
-122 \\
-124.0 \\
-124.0 \\
-124.0 \\
-124.0 \\
-123.8 \\
-123.5\end{array}$ & $\begin{array}{c}\text { kcal/mole } \\
-122 \\
-105.5 \\
-103.7 \\
-101.9 \\
-101.8 \\
-94.4 \\
-87.1\end{array}$ & $\begin{array}{l}92.20 \\
83.00 \\
74.69 \\
74.13 \\
51.57 \\
38.06\end{array}$ \\
\hline $\begin{array}{r}600 \\
700 \\
800 \\
900 \\
1,000\end{array}$ & $\begin{array}{l}-74.14 \\
-77.50 \\
-80.5 € \\
-83.37 \\
-85.95\end{array}$ & $\begin{array}{l}21.22 \\
22.43 \\
23.40 \\
24.19 \\
24.85\end{array}$ & $\begin{array}{r}95.36 \\
99.93 \\
103.96 \\
107.56 \\
110.80\end{array}$ & $\begin{array}{l}12,732 \\
15,701 \\
18,720 \\
21,771 \\
24,850\end{array}$ & $\begin{array}{l}29.36 \\
29.96 \\
30.37 \\
30.66 \\
30.87\end{array}$ & $\begin{array}{l}-123.1 \\
-122.7 \\
-122.3 \\
-121.8 \\
-121.4\end{array}$ & $\begin{array}{l}-79.8 \\
-72.7 \\
-65.5 \\
-58.5 \\
-51.5\end{array}$ & $\begin{array}{l}29.08 \\
22.69 \\
17.91 \\
14.20 \\
11.25\end{array}$ \\
\hline $\begin{array}{l}1,100 \\
1,200 \\
1,300 \\
1,400 \\
1,500\end{array}$ & $\begin{array}{l}-88.35 \\
-90.58 \\
-92.66 \\
-94.62 \\
-96.47\end{array}$ & $\begin{array}{l}25.41 \\
25.88 \\
26.29 \\
26.64 \\
26.96\end{array}$ & $\begin{array}{l}113.76 \\
116.46 \\
118.95 \\
121.26 \\
123.43\end{array}$ & $\begin{array}{l}27,951 \\
31,056 \\
34,177 \\
37,296 \\
40,440\end{array}$ & $\begin{array}{l}31.03 \\
31.15 \\
31.24 \\
31.31 \\
31.38\end{array}$ & $\begin{array}{l}-121.0 \\
-120.6 \\
-120.1 \\
-119.7 \\
-119.3\end{array}$ & $\begin{array}{l}-44.5 \\
-37.6 \\
-30.7 \\
-23.8 \\
-16.9\end{array}$ & $\begin{array}{l}8.84 \\
6.84 \\
5.16 \\
3.71 \\
2.47\end{array}$ \\
\hline
\end{tabular}


TABLE 20. Thermodynamic properties of $\mathrm{BrCl}$ (g)

\begin{tabular}{|c|c|c|c|c|c|c|c|c|}
\hline$T$ & $\left(F^{\circ}-H_{0}^{\circ}\right) / T$ & $\left(H^{\circ}-H_{0}^{\circ}\right) / T$ & $S^{\circ}$ & $H^{\circ}-H_{0}^{\circ}$ & $C_{p}^{\circ}$ & $\Delta H f^{\circ}$ & $\Delta F f^{\circ}$ & $\log K f$ \\
\hline $\begin{array}{l}{ }^{\circ} K \\
0 \\
250 \\
273.16 \\
298.16 \\
300 \\
400 \\
500\end{array}$ & $\begin{array}{c}\text { cal/deg mole } \\
0 \\
-48.485 \\
-49.144 \\
-49.800 \\
-49.847 \\
-52.051 \\
-53.808\end{array}$ & $\begin{array}{c}\text { cal/deg mole } \\
0 \\
7.396 \\
7.466 \\
7.538 \\
7.543 \\
7.783 \\
7.963\end{array}$ & $\begin{array}{c}\text { cal/deg mole } \\
0 \\
55.881 \\
56.610 \\
57.338 \\
57.390 \\
59.834 \\
61.771\end{array}$ & $\begin{array}{c}\text { cal/mole } \\
0 \\
1849.0 \\
2039.4 \\
2247.5 \\
2262.9 \\
3113.2 \\
3981.5\end{array}$ & $\begin{array}{c}\text { cal/deg mole } \\
0 \\
8.17 \\
8.27 \\
8.36 \\
8.37 \\
8.61 \\
8.74\end{array}$ & $\begin{array}{l}\text { kcal/mole } \\
-0.20 \\
-.213 \\
-.212 \\
-.212 \\
-.212 \\
-.21 \\
-.21\end{array}$ & $\begin{array}{c}k c a l / \text { mole } \\
-0.20 \\
-.554 \\
-.586 \\
-.620 \\
-.623 \\
-.76 \\
-.90\end{array}$ & $\begin{array}{l}0.4841 \\
.4686 \\
.4544 \\
.4535 \\
.415 \\
.392\end{array}$ \\
\hline $\begin{array}{r}600 \\
700 \\
800 \\
900 \\
1,000\end{array}$ & $\begin{array}{l}-55.272 \\
-56.528 \\
-57.631 \\
-58.613 \\
-59.498\end{array}$ & $\begin{array}{l}8.100 \\
8.208 \\
8.295 \\
8.366 \\
8.426\end{array}$ & $\begin{array}{l}63.372 \\
64.736 \\
65.926 \\
66.979 \\
67.924\end{array}$ & $\begin{array}{l}4860.0 \\
5745.6 \\
6636.0 \\
7529.4 \\
8426.0\end{array}$ & $\begin{array}{l}8.83 \\
8.88 \\
8.92 \\
8.95 \\
8.98\end{array}$ & $\begin{array}{l}-.21 \\
-.21 \\
-.21 \\
-.21 \\
-.21\end{array}$ & $\begin{array}{l}-1.03 \\
-1.17 \\
-1.31 \\
-1.44 \\
-1.58\end{array}$ & $\begin{array}{l}.376 \\
.365 \\
.357 \\
.350 \\
.346\end{array}$ \\
\hline $\begin{array}{l}1,100 \\
1,200 \\
1,300 \\
1,400 \\
1,500\end{array}$ & $\begin{array}{l}-60.303 \\
-61.043 \\
-61.726 \\
-62.362 \\
-62.956\end{array}$ & $\begin{array}{l}8.477 \\
8.521 \\
\text { 8. } 560 \\
\text { 8. } 594 \\
\text { 8. } 625\end{array}$ & $\begin{array}{l}68.780 \\
69.564 \\
70.286 \\
70.956 \\
71.581\end{array}$ & $\begin{array}{r}9324.7 \\
10225.2 \\
11128.0 \\
12031.6 \\
12937.5\end{array}$ & $\begin{array}{l}9.00 \\
9.02 \\
9.03 \\
9.05 \\
9.06\end{array}$ & $\begin{array}{l}-.21 \\
-.22 \\
-.22 \\
-.22 \\
-.22\end{array}$ & $\begin{array}{l}-1.72 \\
-1.86 \\
-1.99 \\
-2.13 \\
-2.26\end{array}$ & $\begin{array}{l}.341 \\
.338 \\
.335 \\
.332 \\
.330\end{array}$ \\
\hline
\end{tabular}

TABLE 21. Thermodynamic properties of I (g)

\begin{tabular}{|c|c|c|c|c|c|c|c|c|}
\hline$T$ & $\left(F^{\circ}-H_{0}^{\circ}\right) / T$ & $\left(H^{\circ}-H_{0}^{\circ}\right) / T$ & $S^{\circ}$ & $H^{\circ}-H_{0}^{\circ}$ & $C_{p}^{\circ}$ & $\Delta H f^{\circ}$ & $\Delta F f^{\circ}$ & $\log K f$ \\
\hline $\begin{array}{l}{ }^{\circ} K \\
0 \\
250 \\
273.16 \\
298.16 \\
300 \\
400 \\
500\end{array}$ & $\begin{array}{c}\text { cal/deg mole } \\
0 \\
-37.3406 \\
-37.7808 \\
-38.2158 \\
-38.2464 \\
-39.6756 \\
-40.7842\end{array}$ & $\begin{array}{c}\text { cal/deg mole } \\
0 \\
\text { 4. } 9680 \\
\text { 4. } 9680 \\
\text { 4. } 9680 \\
\text { 4. } 9680 \\
\text { 4. } 9680 \\
\text { 4. } 9680\end{array}$ & $\begin{array}{c}\text { cal/deg mole } \\
0 \\
42.3086 \\
42.7488 \\
43.1838 \\
43.2144 \\
44.6436 \\
45.7522\end{array}$ & $\begin{array}{c}\text { cal/mole } \\
0 \\
1242.0 \\
1357.1 \\
1481.3 \\
1490.4 \\
1987.2 \\
2484.0\end{array}$ & $\begin{array}{c}\text { calldeg mole } \\
0 \\
4.9680 \\
4.9680 \\
4.9680 \\
4.9680 \\
4.9680 \\
4.9680\end{array}$ & $\begin{array}{l}\text { kcal/mole } \\
17.77 \\
18.015 \\
18.030 \\
18.042 \\
18.043 \\
18.10 \\
18.15\end{array}$ & $\begin{array}{l}\text { kcal/mole } \\
17.77 \\
15.030 \\
14.752 \\
14.452 \\
14.430 \\
13.22 \\
11.99\end{array}$ & $\begin{array}{c}-13.1386 \\
-11.8029 \\
-10.5932 \\
-10.5119 \\
-7.221 \\
-5.241\end{array}$ \\
\hline $\begin{array}{r}600 \\
700 \\
800 \\
900 \\
1,000\end{array}$ & $\begin{array}{l}-41.6899 \\
-42.4557 \\
-43.1191 \\
-43.7043 \\
-44.2277\end{array}$ & $\begin{array}{l}\text { 4. } 9680 \\
\text { 4. } 9680 \\
\text { 4. } 9680 \\
\text { 4. } 9681 \\
\text { 4. } 9682\end{array}$ & $\begin{array}{l}\text { 46. } 6579 \\
47.4237 \\
48.0871 \\
48.6724 \\
49.1959\end{array}$ & $\begin{array}{l}2980.8 \\
3477.6 \\
3974.4 \\
4471.3 \\
4968.2\end{array}$ & $\begin{array}{l}\text { 4. } 9680 \\
\text { 4. } 9680 \\
\text { 4. } 9682 \\
\text { 4. } 9688 \\
\text { 4. } 9700\end{array}$ & $\begin{array}{l}\text { 18. } 20 \\
\text { 18. } 24 \\
\text { 18. } 29 \\
\text { 18. } 33 \\
\text { 18. } 38\end{array}$ & $\begin{array}{r}10.76 \\
9.51 \\
8.26 \\
7.00 \\
5.74\end{array}$ & $\begin{array}{l}-3.917 \\
-2.969 \\
-2.257 \\
-1.700 \\
-1.255\end{array}$ \\
\hline $\begin{array}{l}1,100 \\
1,200 \\
1,300 \\
1,400 \\
1,500\end{array}$ & $\begin{array}{l}-44.7013 \\
-45.1336 \\
-45.5313 \\
-45.8997 \\
-46.2427\end{array}$ & $\begin{array}{l}\text { 4. } 9685 \\
\text { 4. } 9690 \\
\text { 4. } 9698 \\
\text { 4. } 9711 \\
\text { 4. } 9729\end{array}$ & $\begin{array}{l}49.6698 \\
50.1026 \\
50.5011 \\
50.8708 \\
51.2156\end{array}$ & $\begin{array}{l}5465.4 \\
5962.8 \\
6460.7 \\
6959.5 \\
7459.4\end{array}$ & $\begin{array}{l}\text { 4. } 9726 \\
\text { 4. } 9770 \\
\text { 4. } 9836 \\
\text { 4. } 9925 \\
\text { 5. } 0039\end{array}$ & $\begin{array}{l}18.42 \\
18.47 \\
18.51 \\
18.55 \\
18.60\end{array}$ & $\begin{array}{r}4.48 \\
3.21 \\
1.93 \\
0.66 \\
-.62\end{array}$ & $\begin{array}{r}-0.889 \\
-.584 \\
-.325 \\
-.103 \\
.090\end{array}$ \\
\hline $\begin{array}{l}1,600 \\
1,700 \\
1,800 \\
1,900 \\
2,000\end{array}$ & $\begin{array}{l}-46.5638 \\
-46.8655 \\
-47.1501 \\
-47.4196 \\
-47.6754\end{array}$ & $\begin{array}{l}\text { 4. } 9753 \\
\text { 4. } 9783 \\
\text { 4. } 9818 \\
\text { 4. } 9860 \\
\text { 4. } 9908\end{array}$ & $\begin{array}{l}51.5391 \\
51.8438 \\
52.1319 \\
52.4056 \\
52.6662\end{array}$ & $\begin{array}{l}7960.5 \\
8463.1 \\
8967.2 \\
9473.4 \\
9981.6\end{array}$ & $\begin{array}{l}\text { 5. } 0178 \\
5.0340 \\
5.0521 \\
\text { 5. } 0718 \\
5.0928\end{array}$ & $\begin{array}{l}\text { 18. } 64 \\
18.68 \\
18.73 \\
18.78 \\
18.83\end{array}$ & $\begin{array}{l}-1.90 \\
-3.19 \\
-4.48 \\
-5.77 \\
-7.06\end{array}$ & $\begin{array}{l}.260 \\
.410 \\
.544 \\
.663 \\
.771\end{array}$ \\
\hline $\begin{array}{l}2,100 \\
2,200 \\
2,300 \\
2,400 \\
2,500\end{array}$ & $\begin{array}{l}-47.9190 \\
-48.1516 \\
-48.3742 \\
-48.5874 \\
-48.7923\end{array}$ & $\begin{array}{l}\text { 4. } 9962 \\
\text { 5. } 0021 \\
\text { 5. } 0085 \\
\text { 5. } 0152 \\
\text { 5. } 0224\end{array}$ & $\begin{array}{l}\text { 52. } 9152 \\
53.1537 \\
53.3827 \\
53.6026 \\
53.8147\end{array}$ & $\begin{array}{l}10492.0 \\
11004.6 \\
11519.6 \\
12036.5 \\
12556.0\end{array}$ & $\begin{array}{l}\text { 5. } 1147 \\
5.1371 \\
5.1597 \\
5.1822 \\
\text { 5. } 2045\end{array}$ & $\begin{array}{l}18.88 \\
18.93 \\
18.98 \\
19.03 \\
19.09\end{array}$ & $\begin{array}{r}-8.36 \\
-9.66 \\
-10.96 \\
-12.26 \\
-13.56\end{array}$ & $\begin{array}{r}.870 \\
.959 \\
1.041 \\
1.116 \\
1.185\end{array}$ \\
\hline $\begin{array}{l}2,750 \\
3,000 \\
3,250 \\
3,500 \\
3,750\end{array}$ & $\begin{array}{l}-49.2719 \\
-49.7114 \\
-50.1173 \\
-50.4946 \\
-50.8473\end{array}$ & $\begin{array}{l}5.0414 \\
5.0613 \\
5.0816 \\
5.1015 \\
5.1207\end{array}$ & $\begin{array}{l}\text { 54. } 3133 \\
54.7727 \\
55.1989 \\
55.5961 \\
55.9680\end{array}$ & $\begin{array}{l}13863.8 \\
15183.9 \\
16515.2 \\
17855.2 \\
19202.6\end{array}$ & $\begin{array}{l}\text { 5. } 2571 \\
5.3039 \\
5.3437 \\
\text { 5. } 3762 \\
5.4016\end{array}$ & $\begin{array}{l}19.23 \\
19.69 \\
-0 \\
\end{array}$ & $\begin{array}{l}-16.84 \\
-20.12 \\
-\end{array}$ & $\begin{array}{r}1.338 \\
1.466 \\
\end{array}$ \\
\hline $\begin{array}{l}4,000 \\
4,250 \\
4,500 \\
4,750 \\
5,000\end{array}$ & $\begin{array}{l}-51.1783 \\
-51.4904 \\
-51.7855 \\
-52.0655 \\
-52.3319\end{array}$ & $\begin{array}{l}5.1389 \\
5.1559 \\
5.1716 \\
5.1859 \\
5.1989\end{array}$ & $\begin{array}{l}\text { 56. } 3172 \\
56.6463 \\
56.9571 \\
\text { 57. } 2514 \\
57.5308\end{array}$ & $\begin{array}{l}20555.6 \\
21912.6 \\
23272.2 \\
24633.0 \\
25994.5\end{array}$ & $\begin{array}{l}\text { 5. } 4205 \\
\text { 5. } 4337 \\
\text { 5. } 4419 \\
\text { 5. } 4458 \\
\text { 5. } 4462\end{array}$ & - & - & - \\
\hline
\end{tabular}


TABLE 22. Thermodynamic properties of $\mathrm{I}_{2}(\mathrm{~g})$

\begin{tabular}{|c|c|c|c|c|c|c|c|c|}
\hline$T$ & $\left(F^{\circ}-H_{0}^{\circ}\right) / T$ & $\left(H^{\circ}-H_{0}^{\circ}\right) / T$ & $S^{\circ}$ & $H^{\circ}-H_{0}^{\circ}$ & $C_{p}^{\circ}$ & $\Delta H f^{\circ}$ & $\Delta F f^{\circ}$ & $\log K f$ \\
\hline $\begin{array}{l}{ }^{\circ} K \\
0 \\
250 \\
273.16 \\
298.16 \\
300 \\
400 \\
500\end{array}$ & $\begin{array}{c}\text { cal/deg mole } \\
0 \\
-52.757 \\
-53.467 \\
-54.175 \\
-54.225 \\
-56.586 \\
-58.453\end{array}$ & $\begin{array}{c}\text { cal/deg mole } \\
0 \\
7.980 \\
8.032 \\
8.109 \\
8.114 \\
8.301 \\
8.426\end{array}$ & $\begin{array}{c}\text { cal/deg mole } \\
0 \\
60.737 \\
61.499 \\
62.284 \\
62.339 \\
64.887 \\
66.879\end{array}$ & $\begin{array}{c}\text { cal/mole } \\
0 \\
1995.0 \\
2194.0 \\
2417.8 \\
2434.2 \\
3320.4 \\
4213.0\end{array}$ & $\begin{array}{c}\text { cal/deg mole } \\
0 \\
8.74 \\
8.78 \\
8.81 \\
8.82 \\
8.90 \\
8.95\end{array}$ & $\begin{array}{c}\text { kcal/mole } \\
0 \\
0 \\
0 \\
0 \\
0 \\
0 \\
0\end{array}$ & $\begin{array}{c}k c a l / \text { mole } \\
0 \\
0 \\
0 \\
0 \\
0 \\
0 \\
0\end{array}$ & $\begin{array}{l}0 \\
0 \\
0 \\
0 \\
0 \\
0\end{array}$ \\
\hline $\begin{array}{r}600 \\
700 \\
800 \\
900 \\
1,000\end{array}$ & $\begin{array}{l}-59.998 \\
-61.316 \\
-62.465 \\
-63.485 \\
-64.402\end{array}$ & $\begin{array}{l}8.516 \\
8.584 \\
8.638 \\
8.682 \\
8.719\end{array}$ & $\begin{array}{l}68.514 \\
69.900 \\
71.103 \\
72.167 \\
73.121\end{array}$ & $\begin{array}{l}5109.6 \\
6008.8 \\
6910.4 \\
7813.8 \\
8719.0\end{array}$ & $\begin{array}{l}8.98 \\
9.00 \\
9.02 \\
9.04 \\
9.06\end{array}$ & $\begin{array}{l}0 \\
0 \\
0 \\
0 \\
0\end{array}$ & $\begin{array}{l}0 \\
0 \\
0 \\
0 \\
0\end{array}$ & $\begin{array}{l}0 \\
0 \\
0 \\
0 \\
0\end{array}$ \\
\hline $\begin{array}{l}1,100 \\
1,200 \\
1,300 \\
1,400 \\
1,500\end{array}$ & $\begin{array}{l}-65.234 \\
-65.996 \\
-66.700 \\
-67.354 \\
-67.964\end{array}$ & $\begin{array}{l}8.750 \\
8.778 \\
8.803 \\
8.825 \\
8.845\end{array}$ & $\begin{array}{l}73.984 \\
74.774 \\
75.503 \\
76.179 \\
76.809\end{array}$ & $\begin{array}{r}9625.0 \\
10533.6 \\
11443.9 \\
12355.0 \\
13267.5\end{array}$ & $\begin{array}{l}9.08 \\
9.09 \\
9.11 \\
9.12 \\
9.14\end{array}$ & $\begin{array}{l}0 \\
0 \\
0 \\
0 \\
0\end{array}$ & $\begin{array}{l}0 \\
0 \\
0 \\
0 \\
0\end{array}$ & $\begin{array}{l}0 \\
0 \\
0 \\
0 \\
0\end{array}$ \\
\hline $\begin{array}{l}1,600 \\
1,700 \\
1,800 \\
1,900 \\
2,000\end{array}$ & $\begin{array}{l}-68.535 \\
-69.074 \\
-69.581 \\
-70.063 \\
-70.520\end{array}$ & $\begin{array}{l}8.864 \\
8.881 \\
8.897 \\
8.912 \\
8.927\end{array}$ & $\begin{array}{l}77.399 \\
77.955 \\
78.478 \\
78.975 \\
79.447\end{array}$ & $\begin{array}{l}14182.4 \\
15097.7 \\
16014.6 \\
16932.8 \\
17854.0\end{array}$ & $\begin{array}{l}9.15 \\
9.16 \\
9.18 \\
9.19 \\
9.21\end{array}$ & $\begin{array}{l}0 \\
0 \\
0 \\
0 \\
0\end{array}$ & $\begin{array}{l}0 \\
0 \\
0 \\
0 \\
0\end{array}$ & $\begin{array}{l}0 \\
0 \\
0 \\
0 \\
0\end{array}$ \\
\hline $\begin{array}{l}2,100 \\
2,200 \\
2,300 \\
2,400 \\
2,500\end{array}$ & $\begin{array}{l}-70.956 \\
-71.372 \\
-71.770 \\
-72.152 \\
-72.519\end{array}$ & $\begin{array}{l}8.940 \\
8.953 \\
8.966 \\
8.978 \\
8.989\end{array}$ & $\begin{array}{l}79.896 \\
80.325 \\
80.736 \\
81.130 \\
81.508\end{array}$ & $\begin{array}{l}18774.0 \\
19696.6 \\
20621.8 \\
21547.2 \\
22472.5\end{array}$ & $\begin{array}{l}9.22 \\
9.23 \\
9.25 \\
9.26 \\
9.27\end{array}$ & $\begin{array}{l}0 \\
0 \\
0 \\
0 \\
0\end{array}$ & $\begin{array}{l}0 \\
0 \\
0 \\
0 \\
0\end{array}$ & $\begin{array}{l}0 \\
0 \\
0 \\
0 \\
0\end{array}$ \\
\hline $\begin{array}{l}2,750 \\
3,000\end{array}$ & $\begin{array}{l}-73.377 \\
-74.162\end{array}$ & $\begin{array}{l}9.017 \\
9.041\end{array}$ & $\begin{array}{l}82.394 \\
83.203\end{array}$ & $\begin{array}{l}24796.8 \\
27123.0\end{array}$ & $\begin{array}{l}9.31 \\
9.34\end{array}$ & $\begin{array}{l}0 \\
0\end{array}$ & $\begin{array}{l}0 \\
0\end{array}$ & $\begin{array}{l}0 \\
0\end{array}$ \\
\hline
\end{tabular}

TABLE 23. Thermodynamic properties of IF (g)

\begin{tabular}{|c|c|c|c|c|c|c|c|c|}
\hline$T$ & $\left(F^{\circ}-H_{0}^{\circ}\right) / T$ & $\left(H^{\circ}-H^{\circ}\right) / T$ & $S^{\circ}$ & $H^{\circ}-H_{0}^{\circ}$ & $C_{p}^{\circ}$ & $\Delta H f^{\circ}$ & $\Delta F f^{\circ}$ & $\log K f$ \\
\hline $\begin{array}{l}{ }^{\circ} K \\
\quad 0 \\
250 \\
273.16 \\
298.16 \\
300 \\
400 \\
500\end{array}$ & $\begin{array}{c}\text { cal/deg mole } \\
0 \\
-47.858 \\
-48.496 \\
-49.133 \\
-49.177 \\
-51.308 \\
-53.007\end{array}$ & $\begin{array}{c}\text { cal/deg mole } \\
0 \\
7.177 \\
7.234 \\
7.293 \\
7.297 \\
7.521 \\
7.710\end{array}$ & $\begin{array}{c}\text { cal/deg mole } \\
0 \\
55.035 \\
55.730 \\
56.426 \\
56.474 \\
58.829 \\
60.717\end{array}$ & $\begin{array}{c}\text { cal/mole } \\
0 \\
1794.2 \\
1976.0 \\
2174.5 \\
2189.1 \\
3008.4 \\
3855.0\end{array}$ & $\begin{array}{c}\text { cal/deg mole } \\
0 \\
7.76 \\
7.88 \\
8.00 \\
8.01 \\
8.35 \\
8.56\end{array}$ & $\begin{array}{l}\text { kcal/mole } \\
-30.0 \\
-30.080 \\
-30.082 \\
-30.089 \\
-30.090 \\
-30.10 \\
-30.10\end{array}$ & $\begin{array}{l}\text { kcal/mole } \\
-30.0 \\
-30.354 \\
-30.378 \\
-30.405 \\
-30.407 \\
-30.51 \\
-30.61\end{array}$ & $\begin{array}{l}26.5349 \\
24.3047 \\
22.2868 \\
22.1514 \\
16.670 \\
13.381\end{array}$ \\
\hline $\begin{array}{r}600 \\
700 \\
800 \\
900 \\
1,000\end{array}$ & $\begin{array}{l}-54.427 \\
-55.648 \\
-56.722 \\
-57.680 \\
-58.546\end{array}$ & $\begin{array}{l}7.862 \\
7.987 \\
8.090 \\
8.177 \\
8.250\end{array}$ & $\begin{array}{l}62.289 \\
63.635 \\
64.812 \\
65.857 \\
66.796\end{array}$ & $\begin{array}{l}4717.2 \\
5590.9 \\
6472.0 \\
7359.3 \\
8250.0\end{array}$ & $\begin{array}{l}8.69 \\
8.78 \\
8.84 \\
8.89 \\
8.93\end{array}$ & $\begin{array}{l}-30.10 \\
-30.10 \\
-30.10 \\
-30.10 \\
-30.11\end{array}$ & $\begin{array}{l}-30.72 \\
-30.82 \\
-30.92 \\
-31.03 \\
-31.13\end{array}$ & $\begin{array}{r}11.189 \\
9.622 \\
8.448 \\
7.534 \\
6.803\end{array}$ \\
\hline $\begin{array}{l}1,100 \\
1,200 \\
1,300 \\
1,400 \\
1,500\end{array}$ & $\begin{array}{l}-59.335 \\
-60.060 \\
-60.732 \\
-61.358 \\
-61.943\end{array}$ & $\begin{array}{l}8.314 \\
8.369 \\
8.418 \\
8.461 \\
8.500\end{array}$ & $\begin{array}{l}67.649 \\
68.429 \\
69.150 \\
69.819 \\
70.443\end{array}$ & $\begin{array}{r}9145.4 \\
10042.8 \\
10943.4 \\
11845.4 \\
12750.0\end{array}$ & $\begin{array}{l}8.96 \\
8.99 \\
9.01 \\
9.03 \\
9.05\end{array}$ & $\begin{array}{l}-30.11 \\
-30.11 \\
-30.11 \\
-30.12 \\
-30.12\end{array}$ & $\begin{array}{l}-31.23 \\
-31.33 \\
-31.43 \\
-31.53 \\
-31.63\end{array}$ & $\begin{array}{l}\text { 6. } 205 \\
\text { 5. } 706 \\
\text { 5. } 284 \\
4.923 \\
4.609\end{array}$ \\
\hline
\end{tabular}

TABLE 24. Thermodynamic properties of $\mathrm{IF}_{5}(\mathrm{~g})$

\begin{tabular}{|c|c|c|c|c|c|c|c|c|}
\hline$T$ & $\left(F^{\circ}-H_{0}^{\circ}\right) / T$ & $\left(H^{\circ}-H_{0}^{\circ}\right) / T$ & $S^{\circ}$ & $H^{\circ}-H_{0}^{\circ}$ & $C_{p}^{\circ}$ & $\Delta H I f^{\circ}$ & $\Delta F f^{\circ}$ & $\log K f$ \\
\hline $\begin{array}{l}{ }^{\circ} K \\
\quad 0 \\
250 \\
273.16 \\
298.16 \\
300 \\
400 \\
500\end{array}$ & $\begin{array}{c}\text { cal/deg mole } \\
0 \\
-60.74 \\
-61.95 \\
-63.32 \\
-63.41 \\
-68.19 \\
-72.38\end{array}$ & $\begin{array}{c}\text { cal/deg mole } \\
0 \\
13.89 \\
14.59 \\
15.31 \\
15.37 \\
17.85 \\
19.77\end{array}$ & $\begin{array}{c}\text { cal/deg mole } \\
0 \\
74.63 \\
76.54 \\
78.63 \\
78.78 \\
86.04 \\
92.15\end{array}$ & $\begin{array}{c}\text { cal/mole } \\
0 \\
3472 \\
3985 \\
4565 \\
4611 \\
7140 \\
9885\end{array}$ & $\begin{array}{c}\text { cal/deg mole } \\
0 \\
21.65 \\
22.65 \\
23.70 \\
23.77 \\
26.57 \\
28.19\end{array}$ & $\begin{array}{l}\mathrm{kcal} / \mathrm{mole} \\
-200.68 \\
-202.59 \\
-202.59 \\
-202.6 \\
-202.59 \\
-202.43 \\
-202.15\end{array}$ & $\begin{array}{l}\text { kcal/mole } \\
-200.68 \\
-184.19 \\
-182.47 \\
-180.6 \\
-180.51 \\
-173.17 \\
-165.88\end{array}$ & $\begin{array}{l}161.017 \\
145.987 \\
132.41 \\
131.498 \\
94.613 \\
72.505\end{array}$ \\
\hline $\begin{array}{r}600 \\
700 \\
800 \\
900 \\
1,000\end{array}$ & $\begin{array}{l}-76.13 \\
-79.50 \\
-82.56 \\
-85.36 \\
-87.94\end{array}$ & $\begin{array}{l}21.26 \\
22.44 \\
23.39 \\
24.17 \\
24.83\end{array}$ & $\begin{array}{r}97.39 \\
101.94 \\
105.95 \\
109.53 \\
112.77\end{array}$ & $\begin{array}{l}12756 \\
15708 \\
18712 \\
21753 \\
24830\end{array}$ & $\begin{array}{l}29.18 \\
29.82 \\
30.26 \\
30.57 \\
30.79\end{array}$ & $\begin{array}{l}-201.80 \\
-201.41 \\
-201.02 \\
-200.61 \\
-200.19\end{array}$ & $\begin{array}{l}-158.66 \\
-151.50 \\
-144.40 \\
-137.34 \\
-130.33\end{array}$ & $\begin{array}{l}57.792 \\
47.301 \\
39.447 \\
33.351 \\
28.483\end{array}$ \\
\hline $\begin{array}{l}1,100 \\
1,200 \\
1,300 \\
1,400 \\
1,500\end{array}$ & $\begin{array}{l}-90.33 \\
-92.56 \\
-94.64 \\
-96.60 \\
-98.45\end{array}$ & $\begin{array}{l}25.38 \\
25.85 \\
26.25 \\
26.61 \\
26.92\end{array}$ & $\begin{array}{l}115.71 \\
118.41 \\
120.89 \\
123.21 \\
125.37\end{array}$ & $\begin{array}{l}27918 \\
31020 \\
34125 \\
37254 \\
40380\end{array}$ & $\begin{array}{l}30.96 \\
31.09 \\
31.19 \\
31.27 \\
31.34\end{array}$ & $\begin{array}{l}-199.78 \\
-199.36 \\
-198.95 \\
-198.53 \\
-198.12\end{array}$ & $\begin{array}{r}-123.36 \\
-116.44 \\
-109.54 \\
-102.67 \\
-95.84\end{array}$ & $\begin{array}{l}24.510 \\
21.206 \\
18.415 \\
16.028 \\
13.964\end{array}$ \\
\hline
\end{tabular}


TABLE 25. Thermodynamic properties of $\mathrm{IF}^{7}$ (g)

\begin{tabular}{|c|c|c|c|c|c|c|c|c|}
\hline$T$ & $\left(F^{\circ}-H_{0}^{\circ}\right) / T$ & $\left(H^{\circ}-H_{0}^{\circ}\right) / T$ & $S^{\circ}$ & $H^{\circ}-H_{0}^{\circ}$ & $C_{p}^{\circ}$ & $\Delta H f^{\circ}$ & $\Delta F f^{\circ}$ & $\log K f$ \\
\hline $\begin{array}{l}{ }^{\circ} K \\
\quad 0 \\
250 \\
273.16 \\
298.16 \\
300 \\
400 \\
500\end{array}$ & $\begin{array}{c}\text { cal/deg mole } \\
0 \\
-61.14 \\
-62.64 \\
-64.23 \\
-64.34 \\
-70.32 \\
-75.74\end{array}$ & $\begin{array}{c}\text { cal/deg mole } \\
0 \\
16.40 \\
17.55 \\
18.96 \\
18.81 \\
22.77 \\
25.77\end{array}$ & $\begin{array}{c}\text { cal/deg mole } \\
0 \\
77.54 \\
80.19 \\
82.73 \\
83.15 \\
93.09 \\
101.51\end{array}$ & $\begin{array}{r}\text { cal/mole } \\
0 \\
4100 \\
4794 \\
5585 \\
5643 \\
9108 \\
12885\end{array}$ & $\begin{array}{c}\text { cal/deg mole } \\
0 \\
29.1 \\
30.8 \\
32.3 \\
32.4 \\
36.5 \\
38.8\end{array}$ & $\begin{array}{l}\text { kcal/mole } \\
-228.69 \\
-231.73 \\
-231.72 \\
-231.7 \\
-231.70 \\
-231.37 \\
-230.85\end{array}$ & $\begin{array}{l}\text { kcal/mole } \\
-228.69 \\
-202.27 \\
-199.53 \\
-196.6 \\
-196.37 \\
-184.64 \\
-173.02\end{array}$ & $\begin{array}{c}176.820 \\
159.641 \\
144.10 \\
143.056 \\
100.881 \\
75.625\end{array}$ \\
\hline $\begin{array}{r}600 \\
700 \\
800 \\
900 \\
1,000\end{array}$ & $\begin{array}{l}-80.66 \\
-85.12 \\
-89.21 \\
-92.96 \\
-96.44\end{array}$ & $\begin{array}{l}28.07 \\
29.87 \\
31.31 \\
32.48 \\
33.46\end{array}$ & $\begin{array}{l}108.73 \\
114.99 \\
120.52 \\
125.44 \\
129.90\end{array}$ & $\begin{array}{l}16842 \\
20909 \\
25048 \\
29232 \\
33460\end{array}$ & $\begin{array}{l}40.2 \\
41.1 \\
41.7 \\
42.1 \\
42.4\end{array}$ & $\begin{array}{l}-230.25 \\
-229.61 \\
-228.94 \\
-228.26 \\
-227.56\end{array}$ & $\begin{array}{l}-161.51 \\
-150.10 \\
-138.79 \\
-127.55 \\
-116.41\end{array}$ & $\begin{array}{l}58.830 \\
46.862 \\
37.915 \\
30.974 \\
25.440\end{array}$ \\
\hline
\end{tabular}

TABLE 26. Thermodynamic properties of $\mathrm{ICl}(\mathrm{g})$

\begin{tabular}{|c|c|c|c|c|c|c|c|c|}
\hline$T$ & $\left(F^{\circ}-H_{0}^{\circ}\right) / T$ & $\left(H^{\circ}-H_{0}^{\circ}\right) / T$ & $S^{\circ}$ & $H^{\circ}-H_{0}^{\circ}$ & $C_{p}^{\circ}$ & $\Delta H f^{\circ}$ & $\Delta F f^{\circ}$ & $\log K f$ \\
\hline $\begin{array}{l}{ }^{\circ} K \\
\quad 0 \\
250 \\
273.16 \\
298.16 \\
300 \\
400 \\
500\end{array}$ & $\begin{array}{c}\text { cal/deg mole } \\
0 \\
-48.598 \\
-50.819 \\
-51.486 \\
-51.534 \\
-53.773 \\
-55.555\end{array}$ & $\begin{array}{c}\text { cal/deg mole } \\
0 \\
7.513 \\
7.586 \\
7.660 \\
7.665 \\
7.902 \\
8.073\end{array}$ & $\begin{array}{c}\text { cal/deg mole } \\
0 \\
56.111 \\
58.405 \\
59.146 \\
59.199 \\
61.675 \\
63.628\end{array}$ & $\begin{array}{c}\text { cal/mole } \\
0 \\
1878.2 \\
2072.2 \\
2283.9 \\
2299.5 \\
3160.8 \\
4036.5\end{array}$ & $\begin{array}{c}\text { cal/deg mole } \\
0 \\
8.33 \\
8.42 \\
8.50 \\
8.50 \\
8.70 \\
8.81\end{array}$ & $\begin{array}{c}\text { kcal/mole } \\
-3.33 \\
-3.35 \\
-3.351 \\
-3.352 \\
-3.352 \\
-3.35 \\
-3.35\end{array}$ & $\begin{array}{c}\text { kcal/mole } \\
-3.33 \\
-3.30 \\
-3.723 \\
-3.757 \\
-3.760 \\
-3.90 \\
-4.03\end{array}$ & $\begin{array}{l}2.885 \\
2.9790 \\
2.7539 \\
2.7388 \\
2.129 \\
1.763\end{array}$ \\
\hline $\begin{array}{r}600 \\
700 \\
800 \\
900 \\
1,000\end{array}$ & $\begin{array}{l}-57.039 \\
-58.311 \\
-59.425 \\
-60.416 \\
-61.309\end{array}$ & $\begin{array}{l}8.201 \\
8.301 \\
8.380 \\
8.445 \\
8.499\end{array}$ & $\begin{array}{l}65.240 \\
66.612 \\
67.805 \\
68.861 \\
69.808\end{array}$ & $\begin{array}{l}4920.6 \\
5810.7 \\
6704.0 \\
7600.5 \\
8499.0\end{array}$ & $\begin{array}{l}8.87 \\
8.92 \\
8.95 \\
8.98 \\
9.00\end{array}$ & $\begin{array}{l}-3.34 \\
-3.34 \\
-3.34 \\
-3.34 \\
-3.34\end{array}$ & $\begin{array}{l}-4.17 \\
-4.31 \\
-4.45 \\
-4.58 \\
-4.72\end{array}$ & $\begin{array}{l}1.519 \\
1.345 \\
1.215 \\
1.113 \\
1.032\end{array}$ \\
\hline $\begin{array}{l}1,100 \\
1,200 \\
1,300 \\
1,400 \\
1,500\end{array}$ & $\begin{array}{l}-62.121 \\
-62.866 \\
-63.555 \\
-64.195 \\
-64.793\end{array}$ & $\begin{array}{l}8.546 \\
8.586 \\
8.621 \\
8.652 \\
8.680\end{array}$ & $\begin{array}{l}70.667 \\
71.452 \\
72.176 \\
72.847 \\
73.473\end{array}$ & $\begin{array}{r}9400.6 \\
10303.2 \\
11207.3 \\
12112.8 \\
13020.0\end{array}$ & $\begin{array}{l}9.02 \\
9.04 \\
9.05 \\
9.06 \\
9.08\end{array}$ & $\begin{array}{l}-3.35 \\
-3.35 \\
-3.35 \\
-3.35 \\
-3.35\end{array}$ & $\begin{array}{l}-4.86 \\
-5.00 \\
-5.14 \\
-5.27 \\
-5.41\end{array}$ & $\begin{array}{r}0.966 \\
.910 \\
.863 \\
.823 \\
.788\end{array}$ \\
\hline
\end{tabular}

TABLE 27. Thermodynamic properties of $\mathrm{IBr}(\mathrm{g})$

\begin{tabular}{|c|c|c|c|c|c|c|c|c|}
\hline$T$ & $\left(F^{\circ}-H_{0}^{\circ}\right) / T$ & $\left(H^{\circ}-H_{0}^{\circ}\right) / T$ & $S^{\circ}$ & $H^{\circ}-H_{0}^{\circ}$ & $C_{p}^{\circ}$ & $\Delta H f^{\circ}$ & $\Delta F f^{\circ}$ & $\log K f$ \\
\hline $\begin{array}{l}{ }^{\circ} K \\
0 \\
250 \\
273.16 \\
298.16 \\
300 \\
400 \\
500\end{array}$ & $\begin{array}{c}\text { cal/deg mole } \\
0 \\
-52.501 \\
-53.196 \\
-53.889 \\
-53.938 \\
-56.256 \\
-58.093\end{array}$ & $\begin{array}{c}\text { cal/deg mole } \\
0 \\
7.805 \\
7.877 \\
7.946 \\
7.951 \\
8.161 \\
8.304\end{array}$ & $\begin{array}{c}\text { cal/deg mole } \\
0 \\
60.306 \\
61.073 \\
61.835 \\
61.889 \\
64.417 \\
66.397\end{array}$ & $\begin{array}{c}\text { cal/mole } \\
0 \\
1951.2 \\
2151.7 \\
2369.2 \\
2385.3 \\
3264.4 \\
4152.0\end{array}$ & $\begin{array}{c}\text { cal/deg mole } \\
0 \\
8.62 \\
8.68 \\
8.72 \\
8.72 \\
8.84 \\
8.90\end{array}$ & $\begin{array}{c}\text { kcal/mole } \\
-1.42 \\
-1.42 \\
-1.420 \\
-1.422 \\
-1.422 \\
-1.42 \\
-1.42\end{array}$ & $\begin{array}{c}k c a l / m o l e \\
-1.42 \\
-1.76 \\
-1.796 \\
-1.830 \\
-1.833 \\
-1.97 \\
-2.11\end{array}$ & $\begin{array}{l}1.538 \\
1.4369 \\
1.3417 \\
1.3351 \\
1.076 \\
0.921\end{array}$ \\
\hline $\begin{array}{r}600 \\
700 \\
800 \\
900 \\
1,000\end{array}$ & $\begin{array}{l}-59.617 \\
-60.918 \\
-62.056 \\
-63.066 \\
-63.974\end{array}$ & $\begin{array}{l}8.407 \\
8.486 \\
8.548 \\
8.599 \\
8.641\end{array}$ & $\begin{array}{l}68.024 \\
69.404 \\
70.604 \\
71.665 \\
72.615\end{array}$ & $\begin{array}{l}5044.2 \\
5940.2 \\
6838.4 \\
7739.1 \\
8641.0\end{array}$ & $\begin{array}{l}\text { 8. } 94 \\
8.97 \\
8.99 \\
9.01 \\
9.03\end{array}$ & $\begin{array}{l}-1.42 \\
-1.42 \\
-1.42 \\
-1.42 \\
-1.42\end{array}$ & $\begin{array}{l}-2.24 \\
-2.38 \\
-2.52 \\
-2.66 \\
-2.79\end{array}$ & $\begin{array}{l}.818 \\
.743 \\
.688 \\
.644 \\
.610\end{array}$ \\
\hline $\begin{array}{l}1,190 \\
1,200 \\
1,300 \\
1,400 \\
1,500\end{array}$ & $\begin{array}{l}-64.799 \\
-65.556 \\
-66.254 \\
-66.902 \\
-67.507\end{array}$ & $\begin{array}{l}8.677 \\
8.708 \\
8.736 \\
8.761 \\
8.783\end{array}$ & $\begin{array}{l}73.476 \\
74.264 \\
74.990 \\
75.663 \\
76.290\end{array}$ & $\begin{array}{r}9544.7 \\
10449.6 \\
11356.8 \\
12265.4 \\
13174.5\end{array}$ & $\begin{array}{l}9.05 \\
9.06 \\
9.07 \\
9.09 \\
9.10\end{array}$ & $\begin{array}{l}-1.42 \\
-1.42 \\
-1.42 \\
-1.42 \\
-1.43\end{array}$ & $\begin{array}{l}-2.93 \\
-3.07 \\
-3.20 \\
-3.34 \\
-3.48\end{array}$ & $\begin{array}{l}.582 \\
.559 \\
.538 \\
.521 \\
.507\end{array}$ \\
\hline
\end{tabular}




\section{References}

[1] F. D. Rossini, D. D. Wagman, W. H. Evans, S. Levine, and I. Jaffe, Selected values of chemical thermodynamic properties, NBS Circular 500 (U. S. Government Printing Office, Washington 25, D. C., 1952).

[2] D. D. Wagman, J. E. Kilpatrick, W. J.' Taylor, K. S. Pitzer, and F. D. Rossini, J. Research NBS 34, 143 (1945) RP1634.

[3] H. F. Stimson, J. Research NBS 42, 209 (1949) RP1962.

[4] E. Wichers, J. Am. Chem. Soc. 76, 2033 (1954).

[5] W. H. Evans, R. Jacobson, T. R. Munson, and D. D. Wagman, J. Research NBS 55, 83 (1955) RP2608.

[6] C. E. Moore, Atomic energy levels I, II, III (III, in press), NBS Circular 467 (U. S. Government Printing Office, Washington 25, D. C., 1949-1955).

[7] L. Haar and C. W. Beckett (unpublished calculations).

[8] H. L. Johnston, L. Savedoff, and J. Belzer, Contributions to the thermodynamic functions by a PlanckEinstein oscillator in one degree of freedom, NAVEXOS P-646 (U. S. Government Printing Office, Washington 25, D. C., 1949).

[9] T. L. Collins, A. O. Nier, and W. H. Johnson, Jr., Phys. Rev. 84, 717 (1951).

[10] K. T. Bainbridge and A. O. Nier, Relative isotopic abundances of the elements, Preliminary Report No. 9, Nuclear Science Series, Division of Mathematical and Physical Sciences, National Research Council (1951).

[11] J. E. Mayer and M. G. Mayer, Statistical mechanics, p. 160 (John Wiley \& Sons, Inc., New York, N. Y., 1940).

[12] D. Andrychuk, J. Chem. Phys. 18, 233 (1950).

[13] D. Andrychuk, Can. J. Phys. 29, 151 (1951).

[14] G. Herzberg, Molecular spectra and molecular structure, I. Spectra of diatomic molecules, 2d ed., p. 499 (D. Van Nostrand Co., Inc., New York, N. Y., 1950).

[15] D. A. Gilbert, A. Roberts, and P. A. Griswold, Phys. Rev. 76, 1723 (1949).

[16] A. H. Nielsen and E. A. Jones, J. Chem. Phys. 19, 1117 (1951).

[17] A. H. Nielsen and E. A. Jones, Phys. Rev. 83, 485 (1951).

[18] D. F. Smith, M. Tidwell, and D. V. P. Williams, Phys. Rev. $7 \%, 420$ (1950).

[19] R. A. Durie, Proc. Roy. Soc. (London) [A] 207, 388 (1951).

[20] P. H. Brodersen and H. J. Schumacher, Z. Naturforsch. 2a, 358 (1947).

[21] D. F. Smith, M. Tidwell, and D. V. P. Williams, Phys. Rev. 79, 1007 (1951).

[22] H. C. Mattraw, C. F. Pachucki, and N. J. Hawkins, J. Chem. Phys. 22, 1117 (1954).

[23] H. Stammreich and R. Forneris, J. Chem. Phys. 21, $944(1953)$.

[24] D. H. Rank and W. M. Baldwin, J. Chem. Phys. 19, 1210 (1951).

[25] C. H. Townes, F. R. Merritt, and B. D. Wright, Phys. Rev. 73, 1334 (1948)

[26] V. Schomaker and D. P. Stevenson, J. Am. Chem. Soc. 63, 37 (1941)

[27] G. Herzberg, Molecular spectra and molecular structure, I. Spectra of diatomic molecules, $2 \mathrm{~d}$ ed., p. 90 (D. Van Nostrand Co., Inc., New York, N. Y., 1950).

[28] H. J. Bernstein and J. Powling, J. Chem. Phys. 18, $685(1950)$.

[29] E. A. Jones, J. S. Kirby-Smith, P. J. H. Woltz, and A. H. Nielsen, J. Chem. Phys. 19, 337 (1951).

[30] G. Hettner, R. Pohlman, and H. J. Schumacher, Z. Physik 96, 203 (1935).

[31] G. B. B. M. Sutherland and W. G. Penney, Proc. Roy. Soc. (London) [A] 156, 678 (1936)

[32] J. A. Ibers and V. Schomaker, J. Phys. Chem. 5\%, 699 (1953)

[33] A. H. Nielsen and P. J. H. Woltz, J. Chem. Phys. 20, 1878 (1952).

[34] C. R. Bailey and A. B. D. Cassie, Proc. Roy. Soc. (London) [A] 13\%, 622 (1932).

[35] K. Hedberg, J. Chem. Phys. 19, 509 (1951).
[36] J. B. Coon, Phys. Rev. 58, 926 (1940).

[37] J. B. Coon, J. Chem. Phys. 14, 665 (1946).

[38] J. B. Coon and E. Ortiz, Phys. Rev. 82, 766 (1951).

[39] T. G. Kujumzelis, Physik. Z. 39, 665 (1938)

[40] J. D. Dunitz and K. Hedberg, J. Am. Chem. Soc. 72 , 3108 (1950)

[41] J. B. Coon, Phys. Rev. 85, 746 (1952)

[42] W. H. Stockmayer, G. M. Kavanagh, and H. S. Mickley, J. Chem. Phys. 12, 408 (1944).

[43] C. R. Bailey and A. B. D. Cassie, Proc. Roy. Soc. (London) [A] 142, 129 (1933)

[44] R. Pohlman and H. J. Schumacher, Z. Physik 102, 678 (1936).

[45] E. A. Jones, T. F. Parkinson, and R. B. Murray, J. Chem. Phys. 17, 501 (1949).

[46] K. Schäfer and E. Wicke, Z. Elektrochem. 52, 205 (1948).

[47] D. F. Smith, U. S. Atomic Energy Commission K940, 14 p. (October 27, 1952).

[48] C. V. Stephenson and E. A. Jones, J. Chem. Phys. 20, 1830 (1952).

[49] T. G. Burke and E. A. Jones, J. Chem. Phys. 19, 1611 (1951)

[50] L. Pauling, The nature of the chemical bond (Cornell University Press, Ithaca, N. Y., 1939).

[51] P. W. Allen and L. E. Sutton, Acta Cryst. 3, 46 (1950).

[52] R. C. Lord, M. A. Lynch, Jr., W. C. Schumb, and E. J. Slowinski, Jr., J. Am. Chem. Soc. 72, 522 (1950).

[53] L. Slutsky and S. H. Bauer, J. Am. Chem. Soc. 76 , 270 (1954).

[54] M. W. Nathans, J. Chem. Phys. 18, 1122 (1950).

[55] M. G. Evans, E. Warhurst, and E. Whittle, J. Chem. Soc. 1950, 1524 .

[56] E. Wicke and H. Friz, Z. Elektrochem. 57, 9 (1953)

[57] P. W. Gilles and J. L. Margrave, J. Chem. Phys. 21, 381 (1953).

[58] R. N. Doescher, J. Chem. Phys. 20, 330 (1952).

[59] H. Wise, J. Chem. Phys. 20, 927 (1952).

[60] R. F. Barrow and A. D. Caunt, Proc. Roy. Soc. (London) [A] 219, 120 (1953).

[61] H. von Wartenberg and G. Klinkhott, Z. anorg. u. allgem. Chem. 193, 409 (1930).

[62] O. Ruff and W. Menzel, Z. anorg. u. allgem. Chem. 198, 375 (1931)

[63] A. G. Gaydon, Dissociation energies and spectra of diatomic molecules (Chapman and Hall, Ltd., (London, 1947).

[64] H. von Wartenberg and F. A. Henglein, Ber. 55, 1003 (1922).

[65] F. A. Henglein, Z. anorg. u. allgem. Chem. 123, 137 (1922)

[66] K. Wohl, Z. Elektrochem. 30, 36 (1924).

[67] M. Trautz and F. Geissler, Z. anorg. u. allgem. Chem. 140, 116 (1924)

[68] H. von Wartenberg and D. Weigel, Z. anorg. u. allgem. Chem. 142, 337 (1925).

[69] J. I. Wallace and C. F. Goodeve, Trans. Faraday Soc. 27, 648 (1931).

[70] H. Booth and E. J. Bowen, J. Chem. Soc. 127, 342 (1925).

[71] H. Mayer, Z. physik. Chem, 113, 620 (1924).

[72] W. Finkelnburg and H. J. Schumacher, Z. physik. Chem. Bodenstein-Festband, 704 (1930).

[73] G. Parker and F. J. Wright, Z. Elektrochem. 56, 782 (1952).

[74] A. A. Jakowkin, Z. physik. Chem. 29, 613 (1899).

[75] S. Goldschmidt, Ber. 52, 752 (1919).

[76] W. A. Roth, Z. physik. Chem. [A] 145, 289 (1929).

[77] D. M. Yost and R. C. Felt, J. Am. Chem. Soc. 56, 68 (1934).

[78] J. Thomsen, Thermochemische Untersuchungen [I, II III, IV] (Verlag von J. A. Barth, Leipzig, 1882-1886).

[79] P. Günther and K. Wekua, Z. physik. Chem. [A] 154, 193 (1931).

[80] E. Wicke and H. Friz, Naturwissenschaften 39, 522 (1952).

[81] H. Schmitz and H. J. Schumacher, Z. Naturforsch. 2a, 362 (1947). 
[82] H. Schmitz and H. J. Schumacher, Z. Naturforsch. 2a, 359 (1947).

[83] H. J. Schumacher, H. Schmitz, and P. H. Brodersen, Anales asoc. quím. argentina 38, 98 (1950).

[84] A. L. Warhaftig, J. Chem. Phys. 10, 248 (1942).

[85] O. Ruff and F. Laass, Z. anorg. u. allgem. Chem. 183, $214(1929)$.

[86] H. Schmitz and H. J. Schumacher, Z. Naturforsch. 2a, 362 (1947).

[87] E. P. Perman and G. A. S. Atkinson, Z. physik. Chem. 33, 215 (1900)

[88] E. P. Perman and G. A. S. Atkinson, Z. physik. Chem. 33, 577 (1900)

[89] M. Bodenstein and F. Cramer, Z. Elektrochem. 22, 327 (1916).

[90] T. DeVries and W. H. Rodebush, J. Am. Chem. Soc. 49, 656 (1927).

[91] R. A. Durie and A. G. Gaydon, J. Phys. Chem. 56, 316 (1952).

[92] G. Braune and E. Victor, Z. Elektrochem. 41, 508 (1935).

[93] H. G. Vesper and G. K. Rollefson, J. Am. Chem. Soc. 56, 620 (1934).

[94] L. T. M. Gray and D. W. G. Style, Proc. Roy. Soc. (London) [A] 126, 603 (1930)

[95] C. M. Beeson and D. M. Yost, J. Am. Chem. Soc. 61, 1432 (1939).

[96] W. Jost, Z. physik. Chem. [A] 153, 143 (1931).

[97] H. Braune and H. Ramstetter, Z. physik. Chem. 102, $480(1922)$

[98] G. Starck and M. Bodenstein, Z. Elektrochem. 16, 961 (1910).

[99] M. K. Perlman and G. K. Rollefson, J. Chem. Phys. 9, 362 (1941)

[100] A. A. Woolf, J. Chem. Soc. 1951, 231

[101] R. B. Bernstein and J. J. Katz, J. Phys. Chem. 56, $885(1952)$

[102] W. G. Brown and C. E. Gibson, Phys. Rev. 40, 529 (1932).

[103] J. McMorris and D. M. Yost, J. Am. Chem. Soc. 54, 2247 (1932).

[104] J. McMorris and D. M. Yost, J. Am. Chem. Soc. 53, 2625 (1931)
[105] W. G. Brown, Phys. Rev. 42, 355 (1932)

[106] L. G. Cole, M. Farber, and G. W. Elverum, Jr., J. Chem. Phys. 20, 586 (1952).

[107] G. M. Murphy and J. E. Vance, J. Chem. Phys. \%, 806 (1939).

[108] K. V. Butkov and R. B. Rozenbaum, Zhur. Fiz. Khim. 24, 706 (1950).

[109] J.-H. Hu, D. White, and H. L. Johnston, J. Am. Chem. Soc. 75, 5642 (1953)

[110] R. L. Potter, J. Chem. Phys. 1\%, 957 (1949).

[111] W. F. Giauque and R. Overstreet, J. Am. Chem. Soc. 54, 1931 (1932).

[112] R. H. Sherman and W. F. Giauque, J. Am. Chem. Soc. 75, 2007 (1953)

[113] J. W. M. DuMond and E. R. Cohn, Phys. Rev. 82, 555 (1951).

[114] W. F. Giauque and T. M. Powell, J. Am. Chem. Soc. 61, 1870 (1939).

[115] L. G. Cole and G. W. Elverum, Jr., J. Chem. Phys. 20, $1543(1952)$

[116] M. D. Scheer, J. Chem. Phys. 20, 924 (1952).

[117] J. W. Grisard, H. A. Bernhardt, and G. D. Oliver, J. Am. Chem. Soc. 73, 5725 (1951).

[118] A. Weber and S. M. Ferigle, J. Chem. Phys. 20, 1497 (1952).

[119] A. R. Gordon and C. Barnes, J. Chem. Phys. 1, 692 (1933).

[120] H. Zeise, Z. Elektrochem. 41, 267 (1935).

[121] G. M. Murphy, J. Chem. Phys. 4, 344 (1936).

[122] H. Zeise, Z. Elektrochem. 40, 662 (1934).

[123] H. Schmitz and H. J. Schumacher, Z. Naturforsch. 2a, 363 (1947).

[124] A. A. Banks and M. J. Rudge, J. Chem. Soc. 1950, 191.

[125] R. D. Burbank and F. N. Bensey, J. Chem. Phys. 21, 602 (1953).

[126] M. Bodenstein and A. Schmidt, Z. physik. Chem. 123, 28 (1926)

[127] W. Müller, Z. physik. Chem. 123, 1 (1926).

[128] A. G. Gaydon, Dissociation energies and spectra of diatomic molecules, $2 \mathrm{~d}$ ed., revised (Chapman and Hall, Ltd., London, 1953).

Washington, April 2, 1955. 